Márcia de Andrade Pereira

\title{
ENSINO-APRENDIZAGEM EM UM CONTEXTO DINÂMICO - O CASO DE PLANEJAMENTO DE TRANSPORTES
}

\author{
Tese apresentada à Escola de \\ Engenharia de São Carlos da \\ Universidade de São Paulo, como \\ parte dos requisitos para obtenção do \\ Título de Doutor em Engenharia Civil \\ (Transportes).
}

Orientador: Prof. Dr. Antônio Nélson Rodrigues da Silva

São Carlos

2005 
Ficha catalográfica preparada pela Seção de Tratamento da Informação do Serviço de Biblioteca - EESC/USP

$2436 e$

\section{Pereira, Márcia de Andrade}

Ensino-aprendizagem em um contexto dinâmico - o

caso de planejamento de transportes / Márcia de

Andrade Pereira. -- São Carlos, 2005.

Tese (Doutorado) - Escola de Engenharia de São Carlos-Universidade de São Paulo, 2005.

Área: Transportes.

Orientador: Prof. Dr. Antônio Nélson Rodrigues da Silva.

1. Planejamento de transportes. 2. Processo de ensino-aprendizagem. 3. Estilos de aprendizagem.

4. Alternativas pedagógicas. 5. Recursos tecnológicos.

I. Título. 


\section{DEDICATÓRIA}

Aos meus pais, Marcos e Vânia, e às minhas irmãs Valéria, Gabriela e Marisa pelo amor e força que me deram para eu chegar até aqui. 


\section{AGRADECIMENTOS}

Ao Prof. Dr.Antônio Nélson Rodrigues da Silva pela orientação na realização deste trabalho e pelos conselhos que me deu quando mais precisei.

Ao Conselho Nacional de Desenvolvimento Científico e Tecnológico (CNPq), pela bolsa de estudo concedida.

Ao Programa de Apoio à Pesquisa em Educação a Distância (PAPED) pelo auxílio concedido para o término do trabalho.

A toda minha família, que mesmo distante sempre me apoiou nos momentos alegres e tristes.

Aos funcionários do Departamento de Transportes, em especial à Magali, Heloísa e Beth.

A Fabiana, uma amiga mais que especial, minha irmã de coração, a quem espero ser digna de sua amizade para sempre.

Aos amigos que fiz no Departamento de Transportes, em especial a Marcela, Simone, Cira e Karênina; amigas de todas as horas.

Aos meus amigos Deise e Giovano pela ajuda, amizade e carinho.

Aos meus amigos do CETEPE: Marcia, Martinho, Nídia, Umberto, João Paulo e Renato, pela ajuda na realização desta tese.

Ao Vitor, uma pessoa especial que passou na minha vida.

Aos meus amigos do "Canto do Canto" pela força que me deram nos momentos mais difíceis, pelo carinho, pelos conselhos e pelo amor que mostraram sentir por mim, em especial a minha "mãezinha" Yara. 
A Deus,

Infinitamente bom, que vosso nome seja abençoado pelos benefícios que me concedestes. Eu seria indigna se os atribuísse ao acaso dos acontecimentos ou ao meu próprio mérito.

Desviai de mim a idéia de orgulhar-me pelo que recebo e de não aproveitar tais benefícios somente para o bem. Assim seja... 
"A tecnologia revolucionou os negócios, agora deve revolucionar o aprendizado".

Trade Urban e Cornelia Weggen, W.R. Hambrecht \& Co. 


\section{SUMÁRIO}

LISTA DE FIGURAS vi

LISTA DE TABELAS vii

LISTA DE QUADROS viii

RESUMO ix

ABSTRACT $x$

1. INTRODUÇÃO

1.1. JUSTIFICATIVA

1.2. OBJETIVOS 6

1.3. DESCRIÇÃO DO MÉTODO 6

1.4. ESTRUTURA DO DOCUMENTO

2. PROCESSO DE ENSINO-APRENDIZAGEM 9

2.1. TEORIAS SOBRE O PROCESSO DE ENSINO-APRENDIZAGEM 10

2.1.1. Empirismo 10

2.1.2. Inatismo ou nativismo 11

2.1.3. Interacionismo 11

2.2. FORMAÇÃO DE PROFESSORES: UMA VISÃO CONSTRUTIVISTA (PIAGETIANA) 13

2.3. PARADIGMAS DO ENSINO SUPERIOR 15

2.3.1. Paradigma tradicional 16

2.3.2. Novo paradigma 18 
3. ESTILOS DE APRENDIZAGEM 21

3.1. MODELOS DE ESTILOS DE APRENDIZAGEM 22

3.1.1. Modelo de aprendizagem desenvolvido por Kolb 22

3.1.2. Modelo de aprendizagem de Felder e Silverman 26

3.2. INSTRUMENTOS DE PESQUISA 28

4. RECURSOS TECNOLÓGICOS AUXILIARES NO PROCESSO PEDAGÓGICO 31

4.1. HIPERTEXTO 32

4.2. MULTIMÍDIA 32

4.3. HIPERMÍDIA 33

4.4. INTERNET 34

5. METODOLOGIA SEMIPRESENCIAL 36

5.1. AMBIENTES VIRTUAIS DE APRENDIZAGEM 38

6. MÉTODO DO TRABALHO 45

6.1. ALTERNATIVAS PEDAGÓGICAS 47

6.1.1. Implementação do conteúdo do curso em CD 47

6.1.2. Ambiente desenvolvido na Internet 52

6.1.3. Trabalho em grupo 53

6.1.4. Pesquisa 55

6.1.4.1. Pesquisa à Internet $\quad 55$

6.1.4.2. Pesquisa para desenvolvimento de seminário 56

6.2. SELEÇÃO DOS MÉTODOS / TÉCNICAS DE COLETA DE DADOS 57

6.2.1. Testes de conhecimento 57

6.2.2. Provas 58

6.2.3. Histórico do desempenho dos alunos 58

6.2.4. Seminário $\quad 59$

6.2.5. Registro automático $\quad 59$

6.3. AVALIAÇÃO DOS DADOS 60

6.3.1. Método qualitativo 61 
6.3.1.1. Taxonomia de Bloom

7. APLICAÇÃO DO MÉTODO 64

7.1. APLICAÇÃO DO MODELO DE FELDER E SILVERMAN 64

7.2. APLICAÇÃO DO MODELO DE KOLB 72

7.3. APLICAÇÃO DO MODELO DE CLASSIFICAÇÃO: TAXONOMIA DE BLOOM

8. ANÁLISE DOS RESULTADOS

8.1. AVALIAÇÃO E ANÁLISE DO SOFTWARE WEBCT 79

8.2. ANÁLISE DOS MÓDULOS DO CD SEGUNDO O MODELO DE FELDER E SILVERMAN

8.3. ANÁLISE DOS MÓDULOS DO CD SEGUNDO O MODELO DE KOLB

8.4. ANÁLISE DA APLICAÇÃO DO MODELO DA TAXONOMIA DE BLOOM

8.5. ANÁLISE DOS DADOS QUALITATIVOS

8.5.1. Análise das questões dissertativas

8.5.2. Análise do seminário

8.5.2.1. Avaliação feita pelos alunos

8.5.2.2. Avaliação feita pelo professor

8.5.2.3. Auto-avaliação

8.5.3. Análise das preferências de aprendizagem dos alunos

8.6. ANÁLISE DOS DADOS QUANTITATIVOS

8.6.1. Registro automático

8.6.2. Histórico do desempenho dos alunos

9. CONSIDERAÇÕES FINAIS E SUGESTÕES PARA TRABALHOS FUTUROS 
REFERÊNCIAS BIBLIOGRÁFICAS 


\section{LISTA DE FIGURAS}

Figura 2.1: Elementos essenciais do novo paradigma 19

Figura 3.1: Elementos da aprendizagem 23

Figura 3.2: Ciclo de Kolb - "estilos de aprendizagem" 25

Figura 3.3: Escala do Index of Learning Styles (ILS) 30

Figura 5.1: Página oficial do Blackboard em dez 04

Figura 5.2: Página oficial do First Class em dez $04 \quad 40$

Figura 5.3: Página oficial do Top Class em dez $04 \quad 40$

Figura 5.4: Página oficial do Lotus Learning Space em dez $04 \quad 41$

Figura 5.5: Página oficial do WebCT em dez $04 \quad 42$

Figura 5.6: Página inicial do WebCT no Campus de São Carlos da Universidade de

São Paulo em dez 04

Figura 5.7: Página inicial do WebCT da disciplina em estudo: "Planejamento e Análise de Sistemas de Transportes" em dez 04

Figura 5.8: Página inicial do Col em em marc $05 \quad 44$

Figura 6.1: Rótulo do CD desenvolvido para a disciplina "Planejamento e Análise de Sistemas de Transportes" $\quad 48$

Figura 6.2: Diferentes formas de apresentar um conceito 49

Figura 6.3: Página principal contendo o menu do CD 50

Figura 6.4: Exemplo de um trabalho em grupo 54

Figura 6.5: Relatório de acompanhamento dos alunos no WebCT (cujo nome foi $\begin{array}{ll}\text { omitido intencionalmente) } & 60\end{array}$

Figura 7.1: Dimensões dos estilos de aprendizagem 70

Figura 7.2: Distribuição dos estilos de aprendizagem nas dimensões contempladas pelas "páginas" do módulo apresentado 
Figura 7.3: Avaliação geral do módulo 02

Figura 8.1: Visualização do relatório de acompanhamento dos alunos no WebCT: primeiro acesso, último acesso e número de hits

Figura 8.2: Histórico das páginas visitadas por um aluno (cujo nome foi omitido intencionalmente)

Figura 8.3: Gráficos com a análise geral dos nove módulos do CD segundo o Modelo de Felder e Silverman

Figura 8.4: Avaliação global do $C D$ 85

Figura 8.5: Ciclo de Aprendizagem do Módulo 1 com as páginas em cada fase 87

Figura 8.6: Ciclo de Aprendizagem do Módulo 2 com as páginas em cada fase 88

Figura 8.7: Ciclo de Aprendizagem do Módulo 3 com as páginas em cada fase 89

Figura 8.8: Ciclo de Aprendizagem do Módulo $4 \mathrm{com}$ as páginas em cada fase 90

Figura 8.9: Ciclo de Aprendizagem do Módulo $5 \mathrm{com}$ as páginas em cada fase 91

Figura 8.10: Ciclo de Aprendizagem do Módulo $6 \mathrm{com}$ as páginas em cada fase 92

Figura 8.11: Ciclo de Aprendizagem do Módulo 7 com as páginas em cada fase 93

Figura 8.12: Ciclo de Aprendizagem do Módulo 8 com as páginas em cada fase 94

Figura 8.13: Ciclo de Aprendizagem do Módulo 9 com as páginas em cada fase 95

Figura 8.14: Avaliação feita pelos alunos para o grupo A (RNA) 100

Figura 8.15: Avaliação feita pelos alunos para o grupo B (Lógica Fuzzy) $\quad 100$

Figura 8.16: Avaliação feita pelos alunos para o grupo C (Algoritmos Genéticos) 100

Figura 8.17: Avaliação feita pelos alunos para o grupo D (Sistemas de Informação Geográfica) 100

Figura 8.18: Avaliação feita pelos alunos para o grupo E (Avaliação Multicritério)

Figura 8.19: Avaliação feita pelos alunos para o grupo F (Autômatos Celulares)

Figura 8.20: Avaliação feita pelos alunos para o grupo G (Simulated Annealing)

Figura 8.21: Avaliação feita pelos alunos para o grupo H (Estatística Espacial)

Figura 8.22: Avaliação feita pelo professor para todos os grupos e para todos os fatores

Figura 8.23: Auto-avaliação feita pelos alunos para seus grupos 
Figura 8.24: Média das notas finais dos últimos anos dos alunos que freqüentaram a disciplina "Planejamento e Análise de Sistemas de Transportes" 


\section{LISTA DE TABELAS}

Tabela 2.1: Relação das abordagens tradicional e nova no processo de ensinoaprendizagem

Tabela 3.1: Percentagens dos estilos de aprendizagem observados no trabalho de Kuri (2004)

Tabela 6.1: Algumas das principais ferramentas do WebCT (ícones adaptados) 53

Tabela 6.2: Tabela contendo as 6 categorias ou níveis da Taxonomia de Bloom 63

Tabela 7.1: Percentagens dos Estilos de Aprendizagem predominantes observados na turma de 2004 com seus professores 65

Tabela 7.2: Avaliação das páginas do módulo $02 \quad 71$

Tabela 7.3: Os oito grupos associados às suas técnicas $\quad 77$

Tabela 7.4: Avaliação através da Taxonomia de Bloom utilizada pelo professor $\quad 77$

Tabela 8.1: Primeiro e último acesso dos alunos no WebCT e o número de visitas às páginas

Tabela 8.2: Análise Geral dos módulos do CD de acordo com o Modelo d Felder e Silverman

Tabela 8.3: Resultado da avaliação feita pela Taxonomia de Bloom

Tabela 8.4: Avaliação do recurso utilizado para detecção de absorção ou não do conhecimento

Tabela 8.5: Resultado apresentado pelos alunos sobre suas preferências de aprendizagem com relação aos recursos utilizados pelo professor

Tabela 8.6: Percentagem de alunos que acessaram as páginas do site, de acordo com o número de visitas

Tabela 8.7: Médias das notas finais dos últimos anos dos alunos que freqüentaram a disciplina "Planejamento e Análise de Sistemas de Transportes" 
Tabela 8.8: Avaliação comparativa dos tipos de provas e dos grupos (regular e de controle) da turma de 2004

Tabela 8.9: Avaliação comparativa das turmas de 2004 


\section{LISTA DE QUADROS}

Quadro 6.1: Exemplo da questão dissertativa fornecida para metade da turma 56

Quadro 6.2: Exemplo da questão fornecida a todos os alunos no final do curso 58

Quadro 6.3: Questão objetiva referente a ajuda do CD na aprendizagem 61 


\section{RESUMO}

Pereira, M.A. (2005). Ensino-aprendizagem em um contexto dinâmico - o caso de Planejamento de Transportes. Tese (Doutorado) - Escola de Engenharia de São Carlos, Universidade de São Paulo, 2005.

As rápidas mudanças causadas pelo avanço tecnológico e pelo processo de globalização reforçam a necessidade de se redefinir o perfil do engenheiro para atender as exigências tanto do mercado de trabalho como da sociedade. O surgimento de novas técnicas e ferramentas de análise é uma conseqüência natural deste avanço tecnológico e científico e deveria ser rapidamente incorporado a cursos com forte base tecnológica, como a Engenharia. O desafio para que isto efetivamente ocorra é que o tempo dedicado às disciplinas não pode mais ser ampliado para incorporar novos conteúdos. No entanto, a hipótese desta pesquisa é que, ao mesmo tempo em que fazem parte do problema, as novas tecnologias podem fornecer os recursos necessários para a sua solução. Neste contexto, um novo paradigma para o ensinoaprendizagem é necessário, sendo importante para isto, reconhecer não somente o potencial papel do computador e das ferramentas a ele associadas, como também compreender os diferentes estilos de aprendizagem. Diante disto, o objetivo deste trabalho de tese é explorar e avaliar alternativas para adequação do processo de ensino-aprendizagem ao contexto de rápidas e constantes inovações hoje observado, fazendo-se uso de recursos da hipermídia, fundamentada nos conceitos do construtivismo e testada a partir da introdução de conteúdos inovadores em uma disciplina que trata de Planejamento de Transportes. Através dessa disciplina procurou-se avaliar se os alunos seriam capazes, com a abordagem proposta, de absorver novos tópicos sem comprometer o conteúdo programático tradicional. Para tanto, complementou-se o paradigma tradicional com diversas alternativas pedagógicas (trabalhos em grupo, CD educativo, pesquisas na Internet, WebCT, etc.) em uma turma do terceiro ano do curso de Engenharia Civil. Os resultados encontrados indicam que as alternativas consideradas contribuíram de alguma forma para o aprimoramento da metodologia tradicional, apresentando resultados positivos para o aprendizado. Pode-se afirmar assim que a contribuição desse trabalho para o ensino de Engenharia de Transportes foi significativa, na medida em que demonstra que é possível aprimorar o processo de ensino-aprendizagem, inclusive incorporando novos conteúdos, mesmo diante de uma grade curricular rígida.

Palavras-chave: planejamento de transportes; processo de ensino-aprendizagem; estilos de aprendizagem; alternativas pedagógicas; recursos tecnológicos 


\section{ABSTRACT}

Pereira, M.A. (2005). Teaching-learning in a dynamic context - The case of transportation planning. Dissertation (Doctorate) - São Carlos School of Engineering, University of São Paulo, 2005.

The fast changes produced by the technological development and by the globalization process highlight the need for a new profile of an engineer that can meet the demands of the labor market and of the society. The emergence of new techniques and analyses tools is a natural consequence of that technological and scientific development and it should be immediately incorporated into courses with a strong technological basis, such as Engineering. The challenge to do so is the time constraint imposed to disciplines, which can no longer be increased to include additional topics. However, the hypothesis of this research is that although the new technologies are part of the problem, they can also provide the resources needed for its solution. In such a context, a new paradigm for the teaching learning process is required, in which not only the potential role of the computer itself and of the tools associated to are acknowledged, but also the different learning styles of the students should be taken into account. Therefore, the objective of this research work is to search and evaluation of alternatives for adapting the teaching-learning process to the context of fast and constant innovations currently observed. This is achieved by using multimedia resources for exploring concepts of constructivism, tested with the inclusion of innovative concepts in a Transportation Planning discipline. This experiment was meant to evaluate if the students would be able to grasp new topics along with the long-established contents with the proposed approach. The traditional paradigm was then combined with several pedagogical alternatives (team work, educational CDROM, research on Internet, WebCT, etc.) in a Civil Engineering attended by third-year students. The results found indicate that the alternatives considered have contributed to some extent, to the improvement of the traditional teaching method, bringing positive outcomes to the learning process. Therefore, one can conclude that this study brought a valuable contribution for Transportation Engineering education, given that the teaching-learning process was improved while making possible the inclusion of new topics even in a very inflexible grid course.

Key words: transportation planning, teaching-learning process, learning styles, pedagogical alternatives, technological resources. 


\section{INTRODUÇÃO}

$\mathrm{Na}$ antigüidade, o acesso às informações era muito limitado e restrito a uma pequena elite intelectual que dominava o conhecimento. Atualmente, as informações invadem cada vez mais a rotina das pessoas e tornam-se acessíveis em níveis diferentes da sociedade. Circulam com grande velocidade devido aos avanços da telefonia, das transmissões via satélite e, sobretudo, graças a ampla acessibilidade promovida pela Internet (Tavares e Belhot, 1998).

Nesse sentido, as rápidas mudanças na natureza dos negócios, causadas em grande medida pelo processo de globalização, constantemente redefinem o perfil e as tarefas do engenheiro e redimensionam sua atuação e responsabilidade perante a sociedade (Linsingen et al., 1999). Segundo Silva (1997), esse processo chamado de globalização não é um fenômeno recente, porém sofreu um grande impulso nas últimas décadas, devido principalmente, ao grande desenvolvimento das redes de comunicação e de informação.

Em virtude disto, embora o ensino de Engenharia Civil esteja cumprindo bem o seu papel tradicional, pode estar prescindindo de profundas reflexões sobre a sua prática, visto que não atende plenamente às necessidades hoje exigidas pelo mercado de trabalho.

Segundo Colenci (2000), esta situação foi se modificando por várias razões: escassez de emprego no mercado de trabalho, excesso de conhecimento acumulado pela humanidade, modelos educacionais que não conseguem fazer 
com que os novos conhecimentos sejam absorvidos integralmente por seus alunos, tecnologias para a sua difusão, entre outros. Esses fatores combinados levaram a uma situação incomum: um maior distanciamento entre o conhecimento disponível e os métodos e técnicas disponíveis e aplicados para lidar com ele.

Isto leva a que o engenheiro que ingressa no mercado de trabalho acabe se deparando com a difícil missão de não só aplicar o conhecimento técnico adquirido na escola de engenharia, mas também de adquirir conhecimento de novas técnicas para atender aos requisitos do mercado de trabalho. Diante deste contexto, as instituições responsáveis pelo ensino de engenharia não podem ignorar esta tendência do mercado e precisam suprir o futuro engenheiro com todo o conhecimento técnico de que necessita, inclusive com técnicas mais recentes.

Diversos autores, como Kuri (1998), Linsingen et al. (1999), Boaretto Jr. (1996) e Nakao (2000), vêm pesquisando o perfil adequado para os novos profissionais. Estes e outros afirmam que, para estar apto a enfrentar os desafios do novo cenário mundial, o engenheiro precisa de um sólido conhecimento dos princípios fundamentais da Engenharia Civil, do domínio de aprimoradas estratégias de resolução de problemas e de capacidade para pensar e agir de forma independente. Isto é, o novo perfil requer do profissional, entre outras coisas, o domínio e a capacidade necessárias para poder fazer uso de técnicas novas e emergentes para a solução mais apropriada de problemas complexos.

O desafio aqui é que o tempo dedicado às disciplinas não pode mais ser ampliado para incorporar novos conteúdos. A hipótese desta pesquisa é que, ao mesmo tempo em que fazem parte do problema, as novas tecnologias podem fornecer os recursos necessários para a sua solução. Desta maneira, através desta pesquisa, testa-se esta hipótese ao propor que alunos do curso de graduação entrem em contato com novas formas de ensinoaprendizagem, especificamente em uma disciplina que trata de Planejamento de Transportes. Através dela pretende-se avaliar se os alunos são capazes de 
absorver novos tópicos sem comprometer o conteúdo programático tradicional, dentro do novo paradigma para a educação em engenharia que é aqui defendido. Além disso, a introdução de técnicas emergentes nesta disciplina faz parte da estratégia adotada na pesquisa de melhoria no processo de ensino-aprendizagem.

Kuri (2004) ressalta, nesse sentido, que para se pensar em um ensino transformador, que realmente permita a reconstrução de conhecimento por parte principalmente dos alunos, é necessário também tomar ciência de aspectos não explícitos, ou seja, que estão inseridos dentro do processo de ensino-aprendizagem. Isso, naturalmente, remete à consideração de como se encara o aluno - quais seus interesses, necessidades e estilo particular de aprender. Deve-se reconhecer que os estudantes são diferentes, cada qual com sua própria maneira de receber e processar as informações, resolver problemas e expor idéias, ou seja, cada um tem seu próprio estilo de aprendizagem.

Métodos de ensino, maneiras de apresentar as informações e características de personalidade do professor afetam a aprendizagem e os diferentes estudantes de forma distinta. Isso pode levar o professor a ponderar sobre qual é a melhor maneira de ensinar e como variar os métodos de ensino e as atividades de aprendizagem para atingir o maior número de estudantes possível e facilitar-lhes a aprendizagem.

Em conseqüência disso, novas formas de ensino que modificam o paradigma vigente, quer através da inserção de novas tecnologias, quer através da inserção de técnicas emergentes, vêm sendo pesquisadas, como pode ser visto nos trabalhos de Souza (2001), Freitas (2001), Rodriguez et al. (2001), Smith (2001), Mello et al. (2002), Christie et al. (2002), Herder et al. (2002), e Liu e Fang (2002), entre outros.

Diante deste quadro, vê-se que o ensino assume importância cada vez maior, o que tem levado profissionais da área a procurarem constantemente não somente melhorar seus métodos de ensino, como também compreender os 
diferentes estilos de aprendizagem de modo a possibilitar um direcionamento estratégico-pedagógico para ajudar o aluno a compreender o que é ensinado, melhorando, desta forma, o processo de ensino-aprendizagem.

\subsection{Justificativa}

Os recursos humanos em transportes no Brasil, de um modo geral, não atendem de forma plena e satisfatória às exigências do mercado de trabalho. Este fato está diretamente relacionado com a forma como se dá o processo de ensino-aprendizagem na maioria dos centros de formação. O modelo de ensino tradicional, baseado apenas na metodologia expositiva, é ainda muito utilizado no ensino de engenharia, embora a médio e longo prazos a aplicação única desse modelo tenha poucas chances de sobrevivência diante da explosão da tecnologia da informação.

Nesse sentido, para atender às diferentes preferências de aprendizagem é necessário, antes de tudo, que os educadores possuam uma melhor compreensão da aprendizagem em si, ou seja, reconheçam os diferentes estilos de aprendizagem de seus estudantes e utilizem estratégias instrucionais que incitem o aluno a expor suas idéias, a explicitar suas estratégias de raciocínio e a tomar consciência de suas maneiras de aprender e de comunicar-se.

Com isso, o novo perfil do engenheiro que está sendo requerido nesta transição de milênio exige mudanças no paradigma educacional vigente, no sentido de focalizar o indivíduo como um sujeito contextualizado, dotado de inteligências múltiplas e que constrói o conhecimento em função de sua bagagem genética, cultural e social. O que se espera é um paradigma que valorize o processo de aprendizagem, a atualização constante dos conteúdos, a adoção de currículos flexíveis e adaptados às condições dos alunos, e que respeite o ritmo individual e coletivo nos processos de assimilação e de acomodação do conhecimento. Um paradigma que não apenas reconheça a interatividade e a interdependência entre sujeito e objeto, mas também que 
faça uso de recursos que motivem o aprendizado (som, vídeo, gráficos e animação).

Assim, a partir de um novo paradigma educacional que estimule a inteligência, o desenvolvimento do pensamento e da consciência dos alunos, se estará colaborando para que as novas gerações sejam constituídas de sujeitos capazes de lidarem com a incerteza, com a complexidade na tomada de decisão e de serem mais responsáveis pelas decisões tomadas.

Segundo Kuri (1998), educados apenas através de uma metodologia expositiva, os profissionais que se formam não atendem de forma adequada aos requisitos exigidos pelo mercado de trabalho, havendo portanto uma necessidade de reforma no processo de ensino-aprendizagem, nos métodos de ensino, em geral, e da engenharia, no caso particular dessa pesquisa

Além disso, considerando a carência de pesquisas ligadas à área do ensino de engenharia de transportes no Brasil, fato atestado pelo baixo número de publicações sobre o tema junto à Associação Nacional de Pesquisa e Ensino em Transportes - ANPET, o qual representa menos de $2 \%$ dos trabalhos publicados nos anais de congressos e revistas da Associação no período de 1987 a 2003, esta pesquisa pode representar uma significativa contribuição ao tema. Esta é hoje inclusive uma das principais motivações para o desenvolvimento de pesquisas voltadas ao ensino, na área de Engenharia de Transportes.

Nesse sentido, os esforços dessa pesquisa concentram-se em encontrar alternativas de ensino onde os resultados levem a melhorias concretas no aprendizado da engenharia, incorporando conteúdos inovadores sem abandonar o conhecimento consolidado, mesmo em condições restritas de tempo em sala de aula. 


\subsection{Objetivos}

\section{Objetivo Geral}

- Introdução de um método de ensino inovador numa disciplina que trata de Planejamento de Transportes, no curso de graduação em Engenharia Civil.

\section{Objetivos Secundários}

- Explorar e avaliar alternativas para adequação do processo de ensinoaprendizagem ao contexto de rápidas e constantes inovações hoje observado numa disciplina que trata de Planejamento de Transportes.

- Fazer uso de recursos da hipermídia, fundamentado nos conceitos do construtivismo.

- Testar o uso desses recursos a partir da introdução de um método inovador na disciplina proposta.

\subsection{Descrição do método}

A presente proposta para melhoria no processo de ensino-aprendizagem consiste em fazer com que alunos do curso de graduação em Engenharia Civil entrem em contato com novos métodos de ensino, de forma a não só criar uma aprendizagem individual e interativa, mas também inserir novos tópicos sem alterar o conteúdo programático vigente (grade curricular).

Essa proposta foi testada a partir de uma experiência realizada na disciplina "Planejamento e Análise de Sistemas de Transportes", oferecida aos alunos do terceiro ano do curso de Engenharia Civil da Escola de Engenharia de São Carlos. Essa disciplina é geralmente ministrada por dois docentes do departamento, em turmas com igual número de alunos. Porém, excepcionalmente em 2004 (ano que foi realizada a experiência aqui apresentada), dos sessenta alunos matriculados, quarenta assistiram às aulas participando das inovações sugeridas para complementar a metodologia tradicional. 
Assim sendo, para a turma de quarenta alunos, cujo professor também é o orientador desta pesquisa, foram introduzidas diversas alternativas pedagógicas, tais como: implementação do conteúdo do curso em CD, atualização de um ambiente desenvolvido na Internet, trabalhos em grupo, seminário e pesquisas realizadas com o auxílio da Internet.

Cada uma das alternativas pedagógicas utilizadas foi avaliada através dos métodos quantitativos ou qualitativos, conforme o caso, sempre visando à melhoria no processo de ensino-aprendizagem.

Cabe ressaltar que, para as alternativas pedagógicas de trabalho em grupo e seminário, os quarenta alunos foram divididos em oito grupos de cinco alunos cada. E, nos casos onde os alunos eram conduzidos a atividades na Internet, a turma de quarenta alunos foi dividida em dois grupos, embora os estudantes não soubessem em que grupo haviam sido alocados:

- Grupo de Controle $(n=20)$ - grupo de alunos que realizavam as atividades normais exigidas na disciplina.

- Grupo Experimental $(n=20)$ - grupo de alunos que além de realizar as atividades regulares, era levado a explorar a Internet.

\subsection{Estrutura do documento}

Este trabalho é composto por nove capítulos, estruturados da seguinte forma. Neste primeiro capítulo é apresentada uma introdução sobre o ensino de Engenharia Civil, as necessidades de redefinir o perfil do engenheiro com a era da globalização e a hipótese do trabalho. Ainda nesta seção são apresentados a justificativa do trabalho, o objetivo principal e os secundários e a estrutura deste documento. No capítulo dois é feita uma revisão da literatura que trata do processo de ensino-aprendizagem, onde são discutidas algumas teorias envolvidas neste processo, tais como: empirismo, nativismo e interacionismo. É apresentada também uma visão construtivista e apresentada uma comparação entre os paradigmas de ensino tradicional e o novo, assim como o porquê da necessidade dessa mudança. No capítulo três são abordados dois modelos de 
estilos de aprendizagem que foram utilizados neste trabalho: o de Kolb e o de Felder e Silverman. São também apresentados alguns instrumentos de pesquisa utilizados para a investigação tipológica dos estudantes, dando ênfase ao ILS _ Index Learning Styles. O capítulo quatro trata da importância do papel da tecnologia no ensino, apresentando alguns recursos tecnológicos que auxiliam no processo pedagógico. É feita uma breve discussão sobre o hipertexto, multimídia, hipermídia e Internet. No capítulo cinco é feita uma revisão da literatura que mostra, dentre outras coisas, as vantagens de se adotar uma metodologia semipresencial, também conhecida como b-learning, a fim de aprimorar o processo de ensino-aprendizagem. Nesta seção também são discutidos ambientes virtuais de aprendizagem, como o Blackboard, First class, Top class, Learning space, WebCT e Col. No capítulo seis é apresentado o método do trabalho, onde se discutem as estratégias pedagógicas aqui propostas e como foi realizada sua inserção numa disciplina do curso de Engenharia Civil. Nesta mesma seção são apresentados os métodos de coleta e avaliação de dados utilizados na pesquisa. No capítulo sete é apresentada a aplicação dos métodos utilizados (Kolb e Felder e Silverman), bem como a aplicação do modelo de classifiicação de Taxonomia de Bloom. No capítulo oito é feita uma análise dos resultados obtidos com a aplicação dos modelos utilizados, também é feita uma análise dos softwares WebCT, dos dados qualitativos e quantitativos. Finalmente, no capítulo nove são apresentadas as considerações finais da pesquisa e algumas propostas para trabalhos futuros. Em seguida é apresentada uma lista de referências bibliográficas pertinentes ao trabalho. 


\section{PROCESSO DE ENSINO-APRENDIZAGEM}

Hoje em dia, as informações invadem cada vez mais a rotina das pessoas. Os fatos ocorrem e se alteram de maneira muito rápida e, em muitos casos, de forma imperceptível. Além disso, segundo Colenci (2000), a preocupação e as ações em direção à melhoria da qualidade do ensino de engenharia vêm crescendo de forma significativa, o que tem ensejado inúmeros especialistas a buscar novas estratégias para o processo educacional.

Um dos aspectos que leva à busca por um novo modelo para o processo de ensino e de aprendizagem é o marcante descompasso existente entre ensino praticado e o estágio atual de desenvolvimento tecnológico caracterizado pela real demanda do mercado por profissionais qualificados. O desafio em termos de qualidade do ensino de engenharia está baseado em buscar um novo modelo que incorpore as mudanças tecnológicas e sociais e ofereça alternativas que valorizem o processo de ensino-aprendizagem.

Diante disto, algumas instituições educacionais de diferentes países vêm modificando os métodos de ensino nos seus programas de graduação em Engenharia Civil à medida que incorporam novas técnicas em seus sistemas educacionais. É o caso, por exemplo, da Purdue University (Eidson e Bullock, 2001) e da University of lowa (Nixon, 2000), que vêm utilizando vídeos on-line, páginas da Web e outras formas de mídia como ferramentas para pesquisas.

As principais dificuldades da aprendizagem, estão diretamente relacionadas 
com a relação professor-aluno. O professor precisa ter bom senso e claros seus objetivos. Por exemplo, o superauxílio pode provocar acomodação e a ausência de auxílio a dispersão. No processo de ensino-aprendizagem o interesse, tanto do professor como do aluno, deve ser comum.

Entretanto, para que o objetivo deste trabalho seja alcançado é necessário muito mais do que mudar os métodos de ensino, é preciso considerar o ser humano a partir de diferentes "modelos". Diante disto, psicólogos da Educação vêm há anos dedicando-se ao estudo do desenvolvimento da aprendizagem e têm elaborado diferentes teorias a esse respeito (Barros, 1996). Assim, foram criadas, na Psicologia da Educação, diferentes teorias sobre o processo de ensino-aprendizagem, que serão apresentadas resumidamente na seqüência.

\subsection{Teorias sobre o processo de ensino-aprendizagem}

Cada uma dessas teorias baseia-se num "modelo" de ser humano, isto é, cada uma delas considera o aluno de modo diferente. As diferentes teorias existentes sobre este assunto, segundo Barros (1996), dividem-se em três grupos: o empirismo, inatismo (ou nativismo) e o interacionismo. Estes serão aqui descritos de maneira sucinta para que seja entendido o grupo utilizado no trabalho, para o qual será dado destaque ainda, aos seus principais seguidores.

\subsubsection{Empirismo}

Os adeptos da concepção empirista ou ambientalista acreditam que o desenvolvimento do ser humano depende particularmente do seu ambiente, dos estímulos do meio em que ele vive, das experiências pelas quais ele passa. Conforme estudos feitos por Barros (1996) os adeptos desta corrente acreditam que, ao nascer, o indivíduo não tem conhecimento nenhum. Deste modo, tudo que saberá, aprenderá de fora para dentro, ou seja, através da transmissão do conhecimento do "meio" para o aluno. Esta corrente trouxe alguns efeitos benéficos ao ensino devido à grande importância dada ao professor, à definição dos objetivos do ensino e ao planejamento das aulas. 
Entretanto, considera o indivíduo como um ser passivo, o que vem a ser uma posição muitas vezes criticada. Os principais seguidores dessa teoria são os psicólogos norte-americanos John Broadus Watson (1878-1958) e Burrhus Frederic Skinner (1904-1990).

\subsubsection{Inatismo ou nativismo}

Conforme Barros (1996), os adeptos desta teoria aceitam que, ao nascer, o ser vem equipado com capacidades, aptidões e possibilidades que irão amadurecendo até sua transformação em um adulto. Dessa forma, o professor acredita que a habilidade do aluno depende da formação genética e não da aprendizagem. A educação, diante desta teoria, é um processo de dentro para fora, ou seja, o aluno é um ser ativo, que constrói seu próprio conhecimento. Os principais adeptos desta teoria são os norte-americanos Noam Chomsky (1928- ) e Carl Roger (1902-1987).

\subsubsection{Interacionismo}

Um terceiro modo de entender o ser humano leva em conta tanto fatores orgânicos como fatores ambientais. De acordo com esta teoria, ambos os fatores são importantes na determinação do desenvolvimento do aluno, sendo por isso considerados em sua educação. Os defensores desta teoria não aceitam, em educação, a passividade do aluno. Para eles, a ação do aluno assume a importância máxima, razão pela qual no presente trabalho se adotará essa teoria. Os estereótipos de professor e aluno consagrados pela escola tradicional - professor: ensinar, transmitir e dominar - e aluno: aprender, receber passivamente e obedecer - devem ser mudados, pois segundo essa teoria, apenas assim a instituição de ensino poderá efetivamente atender à sua mais elevada finalidade: permitir ao aluno chegar a construção do seu próprio conhecimento. Os principais adeptos dessa teoria são o russo Lev Vygotsky (1896-1934) e o suíço Jean Piaget (1896-1980).

Lev Vygotsky elegeu a linguagem como objeto de estudo, sendo que ela tinha papel fundamental na mediação entre as relações sociais e a aprendizagem. Segundo Barros (1996), Vygotsky entendia que, para que o indivíduo se constitua como pessoa, é fundamental que ele se insira num determinado 
ambiente cultural. As mudanças que nele ocorrem, ao longo de seu desenvolvimento, estão ligadas à interação dele com a cultura e sociedade da qual faz parte. Sua teoria é conhecida como sócio-interacionista.

Já Jean Piaget interessou-se pelo estudo de como o conhecimento é adquirido (epistemologia). Para ele e seus seguidores, o aluno é um ser ativo que age espontaneamente sobre o meio e possui um modo de funcionamento intelectual próprio que o leva a se adaptar a esse meio e a organizar suas experiências. Pelo contato com objetos e pessoas, o aluno irá construindo seu conhecimento do mundo. Piaget dedicou-se a esse estudo cognitivo, procurando explicar como o aprendiz vai construindo os fenômenos psicológicos. Sua teoria interacionista é conhecida por construtivismo. O princípio pedagógico defendido por Piaget é o de que ensinar é aprender um determinado conhecimento por meio de um ensino centrado no aluno e, portanto, com sua participação ativa em sala de aula (Ribas et al., 1998).

Há contudo convergências e divergências entre os pensamentos de Piaget e Vygotsky. O principal interesse de Piaget era estudar o desenvolvimento da inteligência segundo uma lógica coerente, ou seja, para ele a aprendizagem depende do estágio de desenvolvimento atingido pelo sujeito. Vygotsky, por outro lado, pretendia entender a relação do pensamento com a linguagem, onde esta age decisivamente sobre o raciocínio. Apesar das diferenças entre a posição teórica dos dois cientistas, ambos enfatizam a necessidade da interação do indivíduo com o meio ambiente e vêem o indivíduo como sujeito que atua no processo de seu próprio conhecimento.

O destaque que tanto a teoria construtivista de Jean Piaget como a teoria sócio-interacionista de Lev Vygotsky tem merecido se deve à pertinência com que suas preocupações têm sido difundidas e aplicadas para o ambiente educacional, em especial na didática e em alguns programas de ensino auxiliados por computador. Isto pode ser observado nos trabalhos de Silva (1998), Nitzke (1998), Andrade e Gomes (1998), Matta (2002), Da Nova (2003), Lima (2002), entre outros. Das duas correntes, no entanto, em anos recentes, o 
construtivismo de Piaget foi mais intensamente divulgado no Brasil. Segundo Lima (2002), na ciência da educação, a teoria do construtivismo de Piaget foi a que mais encontrou relação com a proposta de ensino por computador, fato que levou, entre outras coisas, à escolha dessa teoria para fundamentar este documento de tese.

\subsection{Formação de Professores: uma visão construtivista (Piagetiana)}

Segundo Freitas (2001), até a segunda metade do século XX o conhecimento e competência adquiridos no início da atividade profissional eram praticados até o final da carreira, e quase sem alteração. A tendência de apenas transmitir estes ensinamentos era passada de professores a alunos. Entretanto, atualmente, não só as pessoas são muitas vezes levadas a mudarem de profissão, como também, dentro de uma mesma profissão, a aperfeiçoarem constantemente seus conhecimentos profissionais. Segundo Masetto (1992) só recentemente os professores universitários começaram a se conscientizar de que a docência, como a pesquisa e o exercício de qualquer profissão, exige capacitação própria e específica.

Segundo Correia e Cheng (2000), principalmente nas áreas tecnológicas, o professor, via de regra, não teve formação pedagógica e, o sistema de ensino superior tem apontado a prática educacional do professor como uma das suas principais e importantes deficiências. Os professores são, geralmente, profissionais de reconhecida competência técnica sem que apresentem formação docente que os insira no ambiente pedagógico ativo e possibilite a reflexão sobre seu trabalho, de modo a contribuir com análises críticas também dos aspectos humano, social e político na produção de novas tecnologias (Correia e Cheng, 2001).

Colenci (2000) observa que há realmente uma mudança de perfil profissional ocasionada por mudanças sociais e econômicas. Com isso, começa-se a pensar no novo papel do profissional-professor, na importância da metodologia científica, na didática e também na postura da própria universidade que deve atender às necessidades de um mercado em constante evolução ocasionada 
por novas tecnologias.

Correia e Cheng (2001) lembram que o Ministério da Educação e Cultura (MEC), através das Diretrizes Curriculares, dá maior responsabilidade as Instituições de Ensino Superior, docentes, discentes e à sociedade, com o objetivo de fomentar um ensino de graduação com qualidade. No caso específico do ensino de engenharia, no momento, soma-se à esta questão, um constante debate em torno de questões relativas ao perfil do engenheiro, considerando principalmente a sua inserção na denominada era da informação.

O problema da formação inadequada de professores tem sido um grande desafio, visto que em vários fatores (conhecimento, metodologia de ensino, procedimentos de avaliação, e oficinas pedagógicas, entre outros) os professores não se mostram satisfatórios. Neste contexto, diversos são os autores que tratam destes assuntos, tais como: Pérez Gomes (1992), Masetto (1992), Bringhenti (1992), Zeichner (1993), Perrenound (1995), Marcelo (1998), Linsingen et al. (1999), Ferreira (1999), Ribeiro (2000), Nakao (2000), André e Passos (2001), Canen e Grant (2001), Mizukami (2002), dentre outros.

Observa-se, entretanto, que o objetivo desses processos de formação de professores não é fornecer aos docentes mais conhecimento especializado, mas sim treiná-los em métodos didáticos. O professor deve criar o ambiente e as condições de aprendizagem, de forma que os alunos possam conceber o seu próprio processo de aprendizagem.

Sabe-se que hoje, de maneira geral, as universidades não exigem, não oferecem e muito menos estimulam esse tipo de formação para os professores. Por iniciativa própria poucos docentes fazem algum curso de didática. Assim, quase todos ensinam de maneira semelhante à que aprenderam, ou seja, conforme seus mestres ensinavam, sendo esta sua bagagem sobre ensino. Por outro lado, já existem universidades no Brasil, como o caso da Escola Politécnica da USP, mostrado no trabalho de Ferreira (1999), que iniciou em 1999 uma grande reforma curricular: uma campanha visando a especialização de seus professores em técnicas educacionais para o $3^{\circ} \mathrm{grau}$. A finalidade 
principal desta campanha era alterar o paradigma de ensino utilizado até então: aulas expositivas. $O$ estabelecimento de aulas mais dinâmicas, a criação de uma atitude ativa por parte dos alunos e a substituição do ensinar pelo aprender são metas principais de um novo paradigma, afirma Ferreira (1999). Neste sentido, a mera revisão de conteúdos parece insuficiente para garantir a preparação adequada aos profissionais do século XXI. Torna-se necessário então, ainda segundo o autor, a atualização didática dos profissionais.

Alguns pontos falhos da formação docente podem ser observados no trabalho de Pereira e Bazzo (1997):

- Ensino baseado principalmente nos conhecimentos já elaborados;

- Processo educativo sem ligação com o cotidiano, como se fosse uma estrutura meramente acadêmica, independente da vida prática;

- Momento de sala de aula excessivamente centrado no professor, como detentor do conhecimento;

- Ambiente da sala de aula que desencoraja os questionamentos dos alunos, que se inibem com os colegas e com o professor;

- Ensino centrado na memorização e na reprodução de tarefas repetitivas;

- Avaliação da aprendizagem encarada como um ritual de repetição das explicações do professor.

Diante disto, há necessidade dos cursos das universidades brasileiras serem reformulados, não necessariamente como ocorrem nos países de primeiro mundo, como vistos no trabalho de Salum e Guimarães (1996), mas pelo menos para prepararem os recém profissionais da engenharia com o perfil que a sociedade cobra; um profissional ativo, criativo, com liderança, iniciativa, atuação destacada em equipes multidisciplinares, e domínio das modernas técnicas da engenharia. Para tanto, será necessário uma mudança no paradigma de ensino, tema que será abordado no próximo subitem.

\subsection{Paradigmas do Ensino Superior}

Até um passado relativamente recente era possível que fossem formados 
engenheiros para atuarem em um mercado pouco competitivo, com tecnologias que se mantinham em uso por um longo tempo. Hoje, com um mercado de trabalho globalizado, este se tornou extremamente competitivo. Paralelamente a isso, as tecnologias têm se mostrado com vida útil cada vez mais curta devido ao avanço cada vez mais rápido da informatização (Linsingen et al., 1999 e Lima, 2002). Assim, formar um engenheiro com um perfil adequado aos novos tempos significa, antes de tudo, dar-lhe condições para perceber as mudanças e estruturar-se rapidamente numa nova abordagem do processo de ensino-aprendizagem.

Muitos autores estudam um novo paradigma que prepare o futuro profissional para a atuação profissional contemporânea: Gaspareto et al. (1990), Soriano et al. (1992), Leão (1995), Dantas (1993), Ruiz (1994), Beltrão e Schiefler (1995), Pereira e Bazzo (1997), Naegeli et al. (1997), Martins Filho (1997), Kuri (1998), Ribas et al. (1998), Ribeiro (2000), Lima (2002) e Pereira et al. (2003, 2004 e 2005).

Além disso, o estudo realizado por Ribeiro (2000) aponta para as principais diferenças entre os paradigmas novo e tradicional do ensino superior, resumidos na Tabela 2.1 e discutidos nos próximos subitens.

\subsubsection{Paradigma tradicional}

Segundo Colenci (2000), os professores, de uma maneira geral, seguem o esquema giz e lousa e os alunos fazem anotações e estudam para as provas. É o modelo tradicional da educação existente para formar mão de obra e não um profissional multifuncional capaz de pensar e agir com flexibilidade e iniciativa. O aluno, ao receber o conhecimento pronto, não se preocupa em procurar novas soluções para os problemas existentes, ou mesmo identificar novos problemas e, quando ingressa no mercado de trabalho, vai lidar justamente com novas situações. Já os professores, até por falta de matérias pedagógicas em sua formação, não utilizam metodologias de ensino que desenvolvam no aluno novas formas de agir e pensar, apesar de farto material disponível. Geralmente dão aula da forma como aprenderam em sua época de estudante. 
Tabela 2.1: Relação das abordagens tradicional e nova no processo de ensino-aprendizagem

\begin{tabular}{|l|l|}
\hline PARADIGMAS DO ENSINO SUPERIOR \\
\hline ABORDAGEM TRADICIONAL & NOVA ABORDAGEM \\
\hline $\begin{array}{l}\text { Universidade centro de conhecimento isolado da } \\
\text { sociedade }\end{array}$ & $\begin{array}{l}\text { Universidade trabalhando em parceria com a } \\
\text { sociedade }\end{array}$ \\
\hline Universidade vista como uma cidade & Universidade vista como uma idéia \\
\hline Universidade centrada em si própria & $\begin{array}{l}\text { Universidade com foco no mercado e na } \\
\text { sociedade como um todo }\end{array}$ \\
\hline Cursos de 4-5 anos & Educação continuada \\
\hline Ensino em salas de aula da instituição & Ensino em qualquer lugar \\
\hline Conhecimento reproduzido & Conhecimento construído \\
\hline $\begin{array}{l}\text { Aprendizado baseado na memorização, } \\
\text { repetição }\end{array}$ & $\begin{array}{l}\text { Aprendizado baseado na solução de problemas } \\
\text { (aprendendo a aprender) }\end{array}$ \\
\hline Calendário acadêmico fixo & $\begin{array}{l}\text { Funcionamento durante todo o ano. Calendário } \\
\text { flexível }\end{array}$ \\
\hline $\begin{array}{l}\text { Tecnologia como um gasto. Uso pequeno de } \\
\text { meios tecnológicos }\end{array}$ & $\begin{array}{l}\text { Tecnologia como um diferenciador. Uso } \\
\text { imprescindível como suporte dos processos de } \\
\text { ensino-aprendizagem }\end{array}$ \\
\hline
\end{tabular}

Fonte: adaptada e resumida de Ribeiro (2000).

Nos estudos de Bringhenti (1992) nota-se a preferência dos alunos por métodos de ensino que requerem participação mais ativa (96 \%), e baixa indicação pela aula simplesmente expositiva (4 \%). A grande maioria (68 \%) dos alunos do $1^{\circ}$ e do $2^{\circ}$ anos do curso de Engenharia Civil da Escola Politécnica da Universidade de São Paulo sempre, quase sempre ou muitas vezes tiveram professores cujas aulas consistiam apenas em repetir o que estava no livro-texto. Os alunos responderam também que as aulas de um modo geral são exclusivamente expositivas. De acordo com $33 \%$ deles, não é necessário freqüentar as aulas para passar em mais da metade das disciplinas. Nos estudos de Souza (2001) observou-se ainda que $94 \%$ dos alunos nunca tinham participado de um curso semipresencial, e $87 \%$ destes alunos, depois de participarem deste curso semipresencial, fariam outro curso nesse formato se a escola oferecesse. Os números mostram que ainda existem poucas iniciativas no oferecimento de cursos dessa natureza, particularmente no curso de Engenharia Civil da Escola de Engenharia de São Carlos, caso relatado por Souza (2001).

Diante do exposto, pode-se concluir que o método de ensino centrado no professor, onde este traz o conteúdo pronto e o aluno se limita, passivamente, a escutá-lo, é ainda muito utilizado no ensino de engenharia, mas a aplicação 
única desse modelo torna o processo de ensino-aprendizagem pouco eficaz. A questão não está em se rotular a técnica como tradicional e rejeitá-la como método de ensino. Ocorre que professores com atitudes tradicionais poderão tornar uma aula autoritária, monótona e desinteressante, seja ela expositiva ou não. Cabe a ressalva de que não se está desqualificando a aula expositiva; apenas sugere-se que não seja usada em demasia.

Nesse sentido, Mizukami, (1996 apud Kuri, 2004) cita que é necessário salientar que o modelo tradicional de ensino constitui o produto de um trabalho que não deve ser desconsiderado. Representa uma aquisição do conhecimento e assim deve ser reconhecido, pois somente desta forma poderá ser contestado ou superado por outro mais consistente ou que melhor descreva e interprete o fenômeno educativo.

Entretanto, é preciso buscar novas metodologias de ensino, capazes de atender às preferências e necessidades dos alunos, onde o professor possa estabelecer as condições para que o aluno construa seu próprio conhecimento. Como já foi visto, esta é a idéia do construtivismo de Piaget e que serve também de base para o novo paradigma aqui discutido.

\subsubsection{Novo paradigma}

Segundo Levy (1999), nesse novo paradigma de ensino, a principal função do professor já não será a de transmitir conhecimentos mas sim a de incitar seus alunos a pensar e aprender de forma independente. Para permitir essa individualização, o professor deve deixar de ser o responsável pela entrega de informação para ser um guia, um consultor, um companheiro do aluno e o aluno deve assumir o papel ativo na aprendizagem, descobrindo as informações e construindo o seu próprio conhecimento. Aqui, o papel do professor não é o de pensar pelo aluno e sim o de fazer o aluno pensar.

Nesse sentido, no novo paradigma o aluno sai da posição passiva e toma uma posição ativa, pois segundo Borges e Vasconcelos (1997), a aprendizagem só se consolida se o estudante desempenhar um papel ativo de construir seu próprio conhecimento e experiência. O educador, por sua vez, deixará de ser o 
"provedor" da informação e do conhecimento e passará ao papel de "facilitador" da aprendizagem, tornando-se o guia, o parceiro na busca de informação, aquele que incentiva a ativa participação do aluno, que cria condições de estimulá-lo a crescer constantemente na vida pessoal e profissional. Embora aparentemente simples, a mudança do eixo do ensino centrado no professor para o ensino centrado no aluno é muito complexa, pois além de envolver mudanças culturalmente arraigadas nos atores do processo (aluno e professor), envolve ainda investimentos em infra-estrutura das instituições.

Freitas (2001) cita em seu trabalho que, no novo paradigma de educação, a escola necessita de um ambiente especialmente criado para a aprendizagem, rico em recursos e que possibilite ao aluno a construção do seu conhecimento seguindo o seu estilo individual de aprendizagem. Isso é reafirmado por Kuri (1998), que afirma que métodos e técnicas alternativas de ensino e aprendizagem precisam ser consideradas além do modelo tradicional.

Não se trata entretanto, de substituir o paradigma tradicional, mas sim, de complementá-lo. Para tanto, um caminho para que a mudança nos métodos de ensino ocorra da forma mais eficaz possível é através da ação conjunta e não isolada de cada dos elementos observados na Figura 2.1.

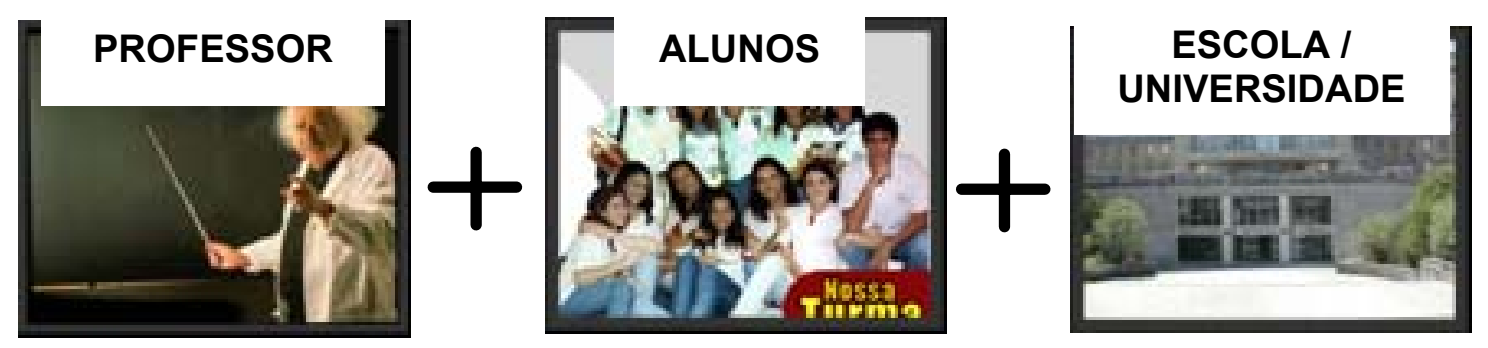

Figura 2.1: Elementos essenciais do novo paradigma

O Professor, com um pensamento "piagetiano" de construir o conhecimento, apresentando aos alunos as novas didáticas e maneiras para se aprender. $O$ Aluno, mantendo acesa a curiosidade de aprender mais e incrementar o desejo do conhecimento, sabendo a importância do porquê construir o conhecimento e, principalmente, manifestando entusiasmo para aprender a aprender. Por fim, 
cabe à Instituição (escola/universidade) deixar de lado a estrutura rígida, permitindo complementar o paradigma de ensino vigente.

Nesse sentido, na busca da maior eficiência do processo de ensinoaprendizagem, conhecer o estilo de aprendizagem dos alunos pode ser de fundamental importância para a definição de estratégias de ensino a serem utilizadas. Este tema será discutido no próximo capítulo. 


\section{ESTILOS DE APRENDIZAGEM}

Esta seção apresenta alguns modelos de estilos de aprendizagem especificamente desenvolvidos para a área da educação de engenharia, bem como alguns instrumentos para sua aplicação.

Identificar os estilos de aprendizagem dos estudantes é fundamental para explicar porque certos métodos de ensino funcionam bem com alguns estudantes e com outros não. Kuri (2004, p. 10) cita que "o fato de um estudante preferir trabalhar sozinho em vez de participar de um grupo; ou ainda, preferir concluir um projeto antes de começar outro em vez de trabalhar em vários projetos paralelos, não é apenas uma curiosidade interessante: é uma informação valiosa que o professor pode usar no aprimoramento da eficácia e de seu ensino".

Assim sendo, Kuri $(2004$, p. 77$)$ cita que "à medida que o professor toma consciência de que cada estudante tem sua própria maneira de aprender e de se relacionar, passa a promover um ensino orientado por esses parâmetros, utilizando estratégias que promovam um aprendizado mais eficaz e duradouro".

Felder e Silverman (1988) vêem a aprendizagem como um processo de duas dimensões, envolvendo a recepção e o processamento da informação. $\mathrm{Na}$ dimensão da recepção, a informação externa que é captada pelos sentidos e a informação interna que surge introspectivamente, ficam disponíveis para o indivíduo, que pode selecionar o material a ser processado e ignorar o restante. Já a dimensão do processamento pode envolver a simples memorização ou o 
raciocínio indutivo ou dedutivo, a reflexão ou a ação, a introspecção ou a interação com outros indivíduos.

Assim sendo, a partir dessas concepções, segundo Kuri (2004), uma definição genérica para estilo de aprendizagem poderia ser: "Estilo de aprendizagem é a maneira pela qual o indivíduo percebe, processa e retêm a informação".

Entretanto, segundo Franco e Braga (2004), quando o estilo de ensino é diferente do estilo de aprendizagem do aluno, este se torna um aluno desinteressado, desatento ou desagregador em classe. Além disso, apresenta baixo desempenho em seu processo de avaliação, desmotivando-se com a disciplina, com o curso e a si mesmo. Daí a importância dos modelos de estilos de aprendizagem durante o planejamento de um curso.

Nesse sentido, sabe-se que os modelos de estilos de aprendizagem têm sido utilizados por diversos autores com o objetivo de comprovar seu potencial para o aprimoramento da aprendizagem na engenharia.

\subsection{Modelos de Estilos de Aprendizagem}

Segundo Correia e Cheng (2000), existem mais de cinqüenta modelos de estilos de aprendizagem. Eles têm sido desenvolvidos por teóricos da educação, na tentativa de explicar como são os processos que geram o aprendizado, identificando que as pessoas percebem e processam as novas informações e experiências de maneiras diferentes. Especificamente neste trabalho, será dado destaque a dois modelos de estilos de aprendizagem: o de Kolb (1984) e o de Felder e Silverman (1988).

\subsubsection{Modelo de aprendizagem desenvolvido por Kolb}

Alguns relatos sobre a aplicação do Modelo de Aprendizagem desenvolvido por Kolb no ensino de engenharia encontrados na literatura (Stice, 1987; Harb et al.,1993; Kuri, 2000; Sharp, 2001; Belhot et al., 2001; etc.) deixam claro que os benefícios de sua implementação são significativos (Kuri, 1998). Para Kolb (1984) o modelo fornece boa estrutura para o planejamento do ensino de engenharia. 
Segundo Harb et al. (1992) o uso do ciclo de aprendizagem aumenta a satisfação dos estudantes que não são atendidos pelas aulas formais, desenvolvendo habilidades, tornando-se independentes e automotivados. A aplicação do ciclo de aprendizagem traz ao docente muitos desafios. Um deles é o fato que exige muito mais tempo do professor do que para a preparação de aulas expositivas. Este deve repassar ao aluno não só os conhecimentos, mas a forma de como trabalhar com eles, criando condições para a plena participação na sociedade através do exercício da cidadania.

O tempo adicional exigido, no entanto, pode ser reduzido através do uso de recursos computacionais e compensado com o desenvolvimento pessoal dos estudantes. Isto viabilizaria, portanto, a inserção do ciclo no novo paradigma de ensino-aprendizagem de forma bastante interessante.

Segundo esse modelo, a aprendizagem pode ser entendida como um processo envolvendo duas dimensões: a percepção da informação e o processamento da informação. Representa-se a função de percepção por uma linha, onde as expressões sentir e pensar estão dispostas em seus pontos finais e opostos. Assim, segundo Harb et al. (1992), a maneira como a pessoa percebe uma nova experiência está localizada em algum ponto desse referencial contínuo. A representação do processamento se dá da mesma maneira, onde as expressões observar e fazer também estão dispostas em seus pontos finais e opostos. Essa estrutura pode ser observada na Figura 3.1.

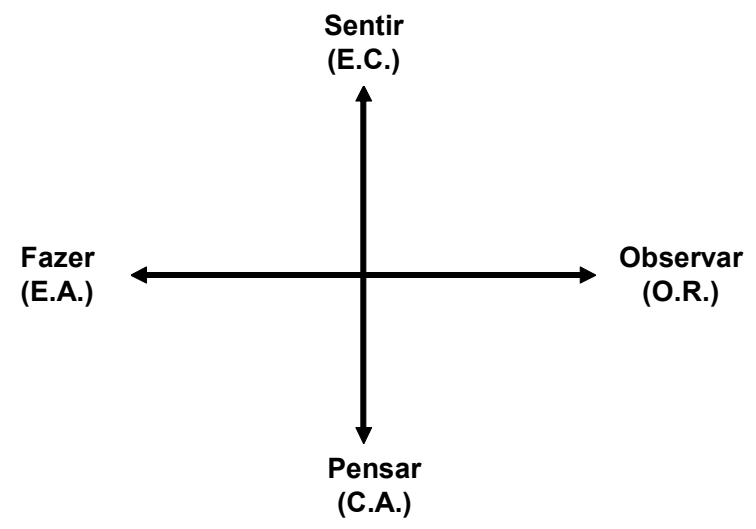

Figura 3.1: Elementos da aprendizagem

Fonte: adaptado de Harb et al. (1992)

Com base nessa Figura, Kolb identificou quatro estágios ou fases. As 
diferentes fases da aprendizagem são descritos a seguir (Pereira et al., 2005).

- Experiência Concreta ( $E C)$ : é o ponto de partida do processo; nesta fase os aprendizes precisam se envolver completa e imparcialmente em novas experiências.

- Observação Reflexiva (OR): nesta fase os aprendizes refletem sobre as novas informações e experiências, examinando-as a partir de diferentes perspectivas.

- Conceituação Abstrata (CA): esta fase envolve mais o uso da lógica e das idéias do que sentimentos para o entendimento dos problemas e situações. Nela os aprendizes precisam criar conceitos que integrem suas observações em teorias sólidas em termos de lógica.

- Experimentação Ativa (EA): nesta fase os aprendizes experimentam ativamente as situações, usando as teorias citadas anteriormente para resolver problemas e tomar decisões.

De acordo com Kolb (1984), existem quatro estilos de aprendizagem, ou seja, alunos que se relacionam melhor com cada um dos estágios do Ciclo de Kolb. São eles: os divergentes, os assimiladores, os convergentes e os acomodadores (Figura 3.2).

1. Divergentes - Percebem as informações pela impressão que elas thes causam, via sensorial $(E C)$ e a processam de modo reflexivo (OR), sem a necessidade de experiência ativa. Imaginação e percepção aguçada de significados e valores são seus pontos fortes, sendo denominados divergentes porque podem ver as coisas de diferentes perspectivas e combinar relacionamentos em um todo significativo. Preferem ouvir e partilhar idéias, são pessoas criativas e inovadoras, tendo facilidade para propôr alternativas, reconhecer problemas e compreender pessoas. Por fim, gostam de saber o valor do que irão aprender.

2. Assimiladores - Percebem a informação com base na compreensão intelectual (CA) e as processam de modo reflexivo (OR). Criar modelos teóricos são seus pontos fortes e são denominados assimiladores 
porque analisam, organizam e assimilam partes da informação, transformando-as em um todo integrado. Integram experiência com conhecimentos já existentes. Utilizam a dedução para a resolução de problemas. São mais interessados pela lógica de uma idéia do que pelo seu valor prático, procuram assimilar novas idéias e pensamentos.

3. Convergentes - Percebem a informação por meio da conceituação abstrata (CA) e as processam ativamente (EA). Resolução de problemas, tomada de decisões e aplicação prática de idéias são seus pontos fortes. São denominados convergentes porque tendem a convergir ou a tomar decisões rapidamente, procurar por uma resposta correta e chegar ao essencial com muita rapidez. De acordo com as pesquisas de Kolb (1984), esse estilo é característico de muitos engenheiros.

4. Acomodadores ou Adaptadores - Percebem a informação por meio da experiência concreta $(E C)$ e a processam ativamente (EA). Suas maiores forças residem em realizar coisas, executar planos e envolverse em novas experiências. São denominados acomodadores porque procuram adaptar o aprendido para seus próprios usos, usando a criatividade para mudar e fazer melhor. São altamente ativos e líderes naturais.

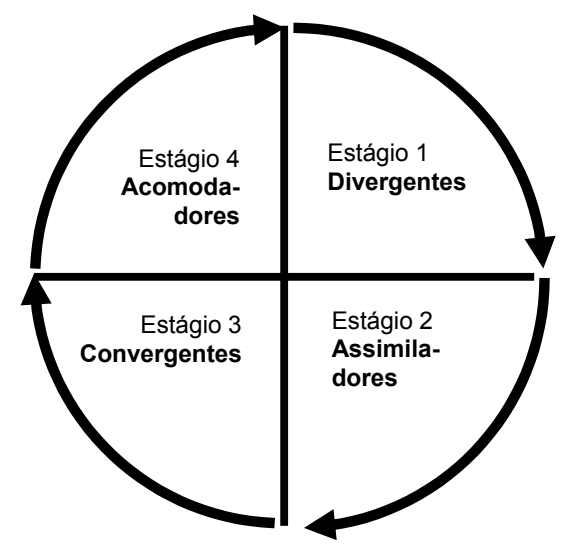

Figura 3.2 - Ciclo de Kolb - "estilos de aprendizagem"

Em termos de ensino, o objetivo seria o professor tentar "caminhar" por todo o ciclo, o que além de atingir bons resultados para o processo de ensino- 
aprendizagem, também atinge diferentes estilos de alunos. Para cada ciclo é preciso identificar o método e a técnica que melhor se ajustam ao processo de ensino-aprendizagem. Entretanto, Freitas (2001) lembra que nem todas as pessoas têm os mesmos interesses, potencialidades, e habilidades e, portanto, não aprendem da mesma maneira. Ele propõe, então, uma educação com a finalidade de atingir o maior número possível de potencialidades, centrada no aluno e na aprendizagem, e não no ensino. Para isso, a chave para a aprendizagem é escolher as ferramentas certas para cada situação e que possam ser variadas de modo a abranger a vasta gama de diferenças individuais.

\subsubsection{Modelo de aprendizagem de Felder e Silverman}

Este modelo classifica o estudante quanto à sua inserção em escalas relativas às maneiras pelas quais prefere perceber e processar as informações. $O$ modelo proposto destina-se à aplicação específica na educação em engenharia e abrange cinco dimensões da aprendizagem: Percepção (Sensorial/Intuitiva), Input (Visual/Verbal), Organização (Indutiva/Dedutiva), Processamento (Ativo/Reflexivo) e Entendimento (Seqüencial/Global).

Diversos são os autores que têm utilizado esse modelo como método para aprimorar o ensino de engenharia. Dentre eles, podemos citar: Zywno e Waalen (2001), Zywno (2003), Tobar e Freitas (2004), Pereira et al. (2004), entre outros.

Segundo Felder e Silverman (1988), o modelo pode ser compreendido através das respostas às cinco questões seguintes:

- Que tipo de informação o estudante percebe preferencialmente?

R: Sensorial (externa) - sinais, sons, sensações físicas; ou

Intuitiva (interna) - possibilidades, palpites, intuições.

- Por qual modalidade a informação sensorial é efetivamente percebida?

R: Visual - gravuras, diagramas, gráficos, demonstrações; ou Auditivo - palavras, sons. 
- Com que organização da informação o estudante se sente mais à vontade?

R: Indutiva - fatos e observações são fornecidas, princípios subjacentes são inferidos, ou Dedutiva - princípios são dados e as aplicações e conseqüências são deduzidas.

- Como o estudante prefere processar a informação?

R: Ativamente - envolvendo-se em atividade física ou discussão, ou por meio da Introspecção Reflexiva

- Como o estudante progride na direção da compreensão? $\mathrm{R}$ : Seqüencialmente - em etapas contínuas, ou Globalmente - em saltos holísticos.

A descrição dos diferentes estilos de aprendizagem identificados a partir desse modelo são apresentadas a seguir, tendo como base o trabalho de Felder e Silverman (1988).

- Sensorial e intuitivo - estudantes sensoriais tendem a ser concretos e metódicos, apreciam fatos, dados, experimentação e resolver problemas usando métodos padronizados. Têm facilidade para memorizar fatos, dados e confiam na memorização como uma estratégia de aprendizagem. Intuitivos tendem a ser abstratos e imaginativos, preferem lidar com princípios, conceitos e teorias. Não gostam de repetição, se enfadam com detalhes e se alegram com complicações.

- Visual e verbal - os visuais preferem que as informações sejam apresentadas em gravuras, diagramas, gráficos, filmes e demonstrações. Verbais preferem explanações faladas ou escritas à demonstração visual, extraindo muito de uma discussão ou explicação.

- Indutivo e dedutivo - estudantes indutivos preferem as apresentações que vão do específico para o geral. Dedutivos preferem começar com os princípios gerais e então deduzir suas conseqüências e aplicações. 
- Ativo e reflexivo - os ativos são pessoas que se sentem mais confortáveis ou mais competentes com a experimentação ativa do que com a observação reflexiva, não aprendem muito em situações que exijam que se comportem passivamente (como a maioria das aulas de preleção). Os reflexivos, por sua vez, não extraem muito de situações que não forneçam oportunidades de pensar sobre a informação que estiver sendo apresentada (como a maioria das aulas de preleção).

- Seqüencial e global - os seqüenciais usam processos mentais lineares na solução de problemas, aprendem melhor quando a matéria é apresentada em uma progressão contínua de complexidade e dificuldade e podem ser fortes no pensamento convergente e análise. Os globais são sintetizadores, aprendem em grandes saltos intuitivos e podem não ser capazes de explicar como chegaram às soluções.

A partir desse modelo, Felder e Soloman criaram um índice de estilos de aprendizagem, ainda em desenvolvimento - o Index of Learning Styles (ILS), que será detalhado no próximo item.

\subsection{Instrumentos de Pesquisa}

Segundo Kuri (2004), muitos são os instrumentos de pesquisa que foram criados para a investigação tipológica dos estudantes. Neste trabalho, serão citados cinco deles, descritos a seguir:

\section{- JTS - Gray-Wheelwrights Jungian Type Survey}

Compõe-se de oitenta e duas questões de escolha forçada que fornecem uma medida das preferências nas dimensões identificadas por Jung.

\section{- MBTI - Myers-Briggs Type Indicator}

O mais conhecido instrumento para identificar os tipos psicológicos. Pode ser utilizado em educação para uma variedade de propósitos, incluindo as seguintes: resolução de problemas, construção de equipes, aconselhamento acadêmico, etc. 


\section{- Keirsey Temperament Sorter}

David Keirsey e Marilyn Bates criaram um instrumento para identificar os diferentes tipos de personalidade e temperamento. Ele fornece uma estrutura para determinar as predisposições ou tendências naturais no comportamento humano.

\section{- LSI - Learning Style Inventory}

O inventário de Estilos de Aprendizagem foi desenvolvido por David Kolb (1984) para avaliar a importância relativa nos quatro modos de aprendizagem experiência concreta $(E C)$, observação reflexiva $(\mathrm{OR})$, conceituação abstrata (CA) e experimentação ativa (EA) - que representam os quatro estágios do processo de aprendizagem.

\section{- ILS - Index of Learning Styles}

Segundo Franco e Braga (2004), Felder e Silverman criaram um instrumento para a determinação dos estilos de aprendizagem e aplicaram a seus alunos do curso de Engenharia Química da North Carolina State University. Os resultados foram usados para adequar algumas disciplinas às características dos alunos. No trabalho de Felder et al. (1988), uma análise científica dessa pesquisa revelou uma substancial melhora no aprendizado.

O ILS é um instrumento auto-aplicável e que tem acesso livre nas páginas da Internet, sendo esta uma das razões de sua escolha para esta pesquisa. Ele tem sido muito utilizado em pesquisas educacionais, notadamente por educadores da área de engenharia e de ciências, para identificar os estilos de aprendizagem dos estudantes. No estudo utilizou-se a versão para o português, de Kuri e Giorgetti (1996).

O Index of Learning Styles contempla quatro das cinco dimensões contidas no modelo de Felder e Silverman. A versão preliminar do ILS continha vinte e oito questões. Revisado, o instrumento abrange quarenta e quatro questões de escolha forçada (alternativa a ou b), sendo onze questões para cada uma das quatro dimensões. De acordo com a interpretação do modelo, o escore entre 1 e 3 indica o equilíbrio entre as duas escalas, entre 5 e 7, preferência moderada e entre 9 e 11, forte preferência por uma das dimensões da escala. Isso pode ser exemplificado através da Figura 3.3. 


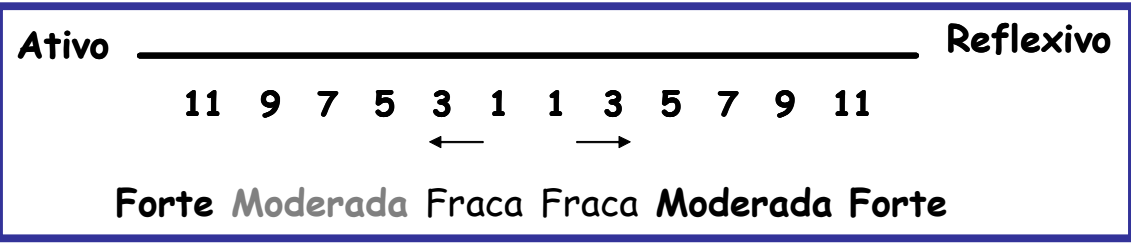

Figura 3.3: Escala do Index of Learning Styles (ILS)

Um exemplo da aplicação deste modelo foi um estudo realizado por Kuri (2004), com o intuito de mostrar a semelhança dos perfis dos alunos das habilitações de engenharia (mecânica, produção, civil e elétrica) da Escola de Engenharia de São Carlos. Os resultados com as turmas do primeiro, terceiro e quinto ano do curso de Engenharia Civil estão discriminados por estilos de aprendizagem na Tabela 3.1. Os resultados observados nesse estudo revelaram percentuais mais elevados nos estilos ativo, sensorial, visual e global. Entretanto, raramente esses estilos de aprendizagem são alcançados pelos métodos de ensino "tradicional".

Tabela 3.1 - Percentagens dos estilos de aprendizagem observados no trabalho de Kuri (2004)

\begin{tabular}{cc}
\hline $\begin{array}{c}\text { Estilos de } \\
\text { Aprendizagem }\end{array}$ & $\begin{array}{c}\text { Alunos do } 1^{\circ}, 3^{\circ} \text { e } 5^{\circ} \text { ano } \\
\text { de Engenharia Civil } \\
(2001)\end{array}$ \\
\hline Ativo & $68 \%$ \\
Reflexivo & $32 \%$ \\
Sensorial & $82 \%$ \\
Intuitivo & $18 \%$ \\
Visual & $83 \%$ \\
Verbal & $17 \%$ \\
Seqüencial & $49 \%$ \\
Global & $51 \%$ \\
\hline
\end{tabular}

Diante de todo o contexto apresentado acima, a participação efetiva no processo de ensino-aprendizagem se dá pela utilização de métodos mais dinâmicos, interativos e atrativos para o aluno, o que pode ser viabilizado através do uso do computador e de inúmeros recursos a ele associados, alguns dos quais discutidos no próximo capítulo. 


\section{RECURSOS TECNOLÓGICOS AUXILIARES NO PROCESSO PEDAGÓGICO}

Segundo Belhot (1997), nesta época de mudanças sociais, a tecnologia está exercendo um papel primordial no ensino. Entre as diversas questões que poderiam ser levantadas, uma parece crucial: o ciclo de vida. O ciclo de vida da tecnologia que pode ser cada vez mais curto, cria dificuldades para o processo educacional, que passa a ter problemas para incorporá-las, pois elas ocorrem mais rapidamente que sua absorção pelo ambiente educacional.

Nesse sentido, Freitas (2001) observa que a introdução de novas tecnologias como recurso de educação é necessária, e, além de servir como viabilizadora de entendimento, faz com que o contexto do aprendizado se aproxime ao máximo do mundo atual: dinâmico e globalizado. Diante disto, observa-se que a produção de conhecimento sobre inovações no ensino não é somente uma necessidade, mas uma imposição do momento histórico.

No campo da educação, os avanços tecnológicos em hardware e software constituem recursos que permitem a introdução de novas técnicas capazes de enriquecer o processo de ensino-aprendizagem (Boaretto Jr., 1996). Segundo Lima (1996), a intensidade da incorporação do computador nos sistemas educacionais pode ser observada a partir de algumas estatísticas: o Japão possui $100 \%$ de suas escolas com salas de aula informatizadas; os EUA superam os $80 \%$ neste quadro; alguns países da Europa alcançam os $90 \%$. No caso do Brasil, a educação ainda sofre com uma ação lenta no que se refere a 
informatização do processo de ensino.

O problema aqui, entretanto, não é apenas possuir o recurso pedagógico. É necessário possuir o recurso e utilizá-lo a fim de formar um engenheiro competente para o desempenho de sua função. Diante dos fatos relatados, sabe-se que atualmente existem diversos recursos de tecnologias que são usados com o intuito de promover uma melhoria no processo de ensinoaprendizagem. A seguir, serão apresentados alguns recursos tecnológicos utilizados para atender às mais diversas áreas, permitindo, desta forma, transformar o computador em um novo meio de acesso à informação e ao conhecimento.

\subsection{Hipertexto}

Guerra (2000) identificou que, com o aparecimento da escrita, o homem passou a utilizar o texto como o principal meio de representação do conhecimento. No texto tradicional, seja na forma impressa ou em arquivos de computador, a informação, os conceitos e idéias são apresentadas ao leitor em uma forma seqüencial. O hipertexto veio para quebrar essa limitação.

Segundo Belhot (1997), o hipertexto é uma solução tecnológica para organizar o acesso à informação. Ele organiza o armazenamento das informações de um documento, permitindo a realização de pesquisas não seqüenciais, ou seja, neste não existe uma ordem que determine a seqüência na qual o texto deve ser lido. Apresenta várias opções diferentes para os leitores, que determinam qual delas seguir na hora da leitura. Isto significa alternativas para que o usuário explore o conhecimento de acordo com as suas necessidades.

\subsection{Multimídia}

Com a introdução da multimídia, a interação usuário-máquina modificou-se radicalmente, conjugando o acesso a informações com imagens, vídeo e áudio. A multimídia é a combinação das diversas formas de comunicação, que está presente no cotidiano das pessoas nos mais diversos lugares: caixas 
automáticos, terminais de informações, aparelhos de TV, etc.

De acordo com Boaretto Jr. (1996), a multimídia é considerada uma das maiores transformações tecnológicas na computação dos últimos tempos. Apresenta como vantagens a interatividade (capacidade que o programa tem de responder a estímulos e ações do usuário) e a capacidade de atuar em harmonia com o hipertexto, possibilitando que informações com diferentes formatos sejam acessadas de forma não linear. Nessa situação, a multimídia passa então a se chamar hipermídia.

\subsection{Hipermídia}

O termo hipermídia refere-se à associação do hipertexto com a multimídia. Reúne a flexibilidade de navegação dos sistemas hipertextos com a diversidade de recursos oferecidos pela multimídia. Trata-se de uma estrutura que permite a leitura de seus dados de forma não seqüencial por meio de associações, contendo ainda diversas mídias como, por exemplo, textos (também em forma não linear), sons, imagens estáticas e em movimento, vídeos, gráficos, etc.

Segundo Freire (1998), a utilização da hipermídia em ambientes de ensino oferece uma maior flexibilidade de uso e uma melhor apresentação das informações aos usuários. Além disso, devido aos recursos audiovisuais normalmente disponíveis, ela também estimula os alunos a aprender.

Um sistema hipermídia proporciona ao aluno suporte para expressar-se em suas diferentes habilidades e avaliar sua aprendizagem através de dispositivos multissensoriais que o ambiente oferece. Para tanto é necessário que o ambiente ou projeto a ser desenvolvido permita que o aluno trabalhe nele ativamente, preferencialmente fazendo parte da construção e não apenas navegando nele (Freitas, 2001). Ainda segundo o mesmo autor, através de recursos hipermídia foram desenvolvidos na educação diversos trabalhos na década de 1970 e 1980, em artes, arqueologia, medicina, espanhol, etc. O sistema hipermídia mais conhecido e utilizado atualmente, segundo Guerra 
(2000), é a própria Internet.

\section{$4.4 \quad$ Internet}

A Internet é a mídia que mais cresce em todo o mundo. Ela está promovendo mudanças sociais, econômicas e culturais. Facilita a motivação dos alunos pelas inúmeras possibilidades de pesquisas que oferece. Rompe barreiras físicas e de tempo, permitindo o compartilhamento de informações e a comunicação em tempo real. O seu uso introduz um novo modo de lidar com a informação e com o conhecimento, criando formas alternativas de estudo e de pesquisa, com impacto direto no processo de ensino-aprendizagem.

Segundo Lima (2002), não é mais possível falar de ensino por computador sem citar a Internet, tamanho é o potencial que essa tecnologia propicia ao processo de aprendizagem. Nesse sentido, segundo Assayag (1996), existem infinitas utilizações da Internet na engenharia:

a) Criação e/ou participação em listas de discussão em torno de temas de interesse comum, aproximando os participantes, mesmo que estejam distantes geograficamente, uns dos outros;

b) Meio do profissional ou estudante manter contato com rapidez com os grandes centros de ensino, para divulgação de novos materiais, experiências, etc.;

c) Superação da falta de referências bibliográficas em algumas áreas específicas;

d) Acompanhamento das tendências atuais de globalização que envolvem a produção, a economia, as áreas de interesse ambiental, os centros urbanos, entre outros.

Entretanto, segundo Tajra (2001), a Internet apresenta, além das vantagens, algumas problemáticas:

\section{Vantagens:}

- Acessibilidade a fontes inesgotáveis de assuntos para pesquisas;

- Comunicação e interação com outras universidades; 
- Desenvolvimento de uma nova forma de comunicação e socialização;

- Estímulo à curiosidade;

- Estímulo ao raciocínio lógico;

- Desenvolvimento da autonomia;

- Troca de experiências entre professores/professores, professores/alunos e, alunos/alunos;

\section{Problemáticas:}

- Muitas informações sem fidedignidade;

- Facilidade na dispersão durante a navegação;

- Lentidão no acesso aos sites.

Apesar dos problemas, ela possibilita a instauração de um ambiente educacional que contemple os paradigmas do construtivismo, que é objeto desse trabalho de tese; e seja transcendente, ou seja, ultrapasse os limites de tempo e espaço. Alguns desses aspectos serão identificados no capítulo a seguir. 


\section{METODOLOGIA SEMIPRESENCIAL}

O interesse constante das instituições de ensino com respeito às novas maneiras de ensinar e de aprender através da Internet já é fato. Alguns exemplos de instituições que oferecem esse tipo de aprendizagem, segundo Rosenberg (2002), são:

- Penn State University: www.worldcampus.psu.edu

- Florida State University: www.fsu.edu/ distance

- Kentucky Commonwealth Virtual University: www.kcvu.org

- State University of New York: sln.suny.edu/admin/sIn/original.nsf

- University of Maryland: www.umuc.edu/distance/index.html

- Western Governor University: www.wgu.edu

Diante disto, segundo Keegan et al. (2002), com os recursos das novas tecnologias de informação e formação, capazes de incentivar a autoaprendizagem, encurtar as distâncias, otimizar os recursos e igualizar as oportunidades, o e-learning (electronic learning) tem um papel fundamental na aprendizagem. Acreditando ser o modelo de ensino do futuro, diversos autores utilizam o e-learning para aprimorarem seus métodos de ensino. Dentre eles pode-se citar: Machado (2001), Santos (2001), Kovalinka (2003), Taraman (2004), etc. 
Kaplan Leiserson ${ }^{1}$ (apud Keegan et al., 2002) apresenta a seguinte definição para o termo e-learning: "abrange um vasto conjunto de aplicações e processos, como a aprendizagem baseada na web, aprendizagem baseada no computador, salas de aula virtuais e colaboração digital. Inclui a disponibilização de conteúdos através da Internet, Intranet, cassetes áudio e vídeo (sic), transmissão por satélite, TV interativa e CD."

Porém, o termo e-learning é freqüentemente utilizado de modo mais genérico e como sinônimo de educação on-line. Além disso, muitas vezes é empregado de maneira errônea, como transposição do paradigma educacional vigente para o formato eletrônico ou simplesmente o livro na tela.

Neste sentido, segundo observações de Tajra (2001), a Internet não substitui o professor. Ela pode facilitar o aprimoramento das relações humanas, pode permitir a elaboração de novas formas de produção, pode estimular uma cultura digital, pode liberar tempo, e pode unir povos e culturas. Contudo, é preciso propiciar a interação e dinamismo entre os alunos/professores e os recursos da web. É preciso não esquecer da importância do relacionamento humano face a face.

Assim, para melhor corresponder às necessidades dos alunos/professores, optou-se por utilizar neste projeto de tese a metodologia semipresencial de aprendizagem (b-learning). Também conhecido como blended learning ${ }^{2}$, este conceito representa a noção de mistura entre a formação a distância e presencial. O sucesso do b-learning, do ponto de vista metodológico, resulta exatamente da capacidade de misturar equilibradamente diversas metodologias e tecnologias com o objetivo de melhorar a eficácia e eficiência do processo de ensino-aprendizagem.

Segundo Ferreira (2004), esse tipo de aprendizagem contribui para um ensino de melhor qualidade e desempenha um papel de catalizador da mudança do

\footnotetext{
${ }^{1}$ Kaplan - Leiserson, E. E-learning Glossary. Disponível em: $<$ http://www.learningcircuits.org/glossary.html>

2 Uma alternância ao serviço da pedagogia (sic). Disponível em: http:www.cegoc.pt/elearning/conceitosmistos.html. Acessado em 10 de jun. de 2003.
} 
processo de ensino. Possibilita um maior intercâmbio e troca de conhecimentos, reforça a autonomia dos alunos e incentiva a sua iniciativa.

A Implementação do e-learning para o ensino a distância, ou do b-learning para o ensino semipresencial, se faz através da utilização dos Sistemas de Gestão da Aprendizagem (Learning Management Systems - LMSs), também chamados de Ambientes Virtuais de Aprendizagem.

\subsection{Ambientes Virtuais de Aprendizagem}

Também conhecido por Sistema de Gestão da Aprendizagem, Ambiente de Gestão de Aprendizagem ou por Plataforma E-learning, o LMS é um sistema que permite a organização e o acesso a serviços de aprendizagem on line para estudantes, professores e administradores.

Segundo Pereira (2004), esses sistemas incluem normalmente o controle de acesso, a disponibilização de conteúdos de aprendizagem, ferramentas de comunicação e organização de grupos de usuários. Pode permitir ainda, segundo Figueira (2003), a geração automática de testes, criando uma base de dados de questões que, classificadas de acordo com um conjunto de critérios, geram testes com o mesmo nível de dificuldade.

Existem diversos ambientes virtuais de aprendizagem que as instituições ou empresas de formação podem utilizar, como: Blackboard (americano), First Class (canadense), Top Class (irlandês), Learning Space (americano), WebCT (canadense) e Col (brasileiro). Uma breve descrição de cada um deles será feita a seguir. Embora não tenham sido citados neste trabalho, existem outros sistemas, alguns dos quais feitos sob medida e com forte implantação no norte da Europa, principalmente na Alemanha (Pereira, 2004).

\section{- Blackboard}

Segundo Souza (2001), o Blackboard se tornou um provedor para e-learning, ou seja, os cursos são hospedados diretamente no site da empresa. Desde sua fundação em 1997, o Blackboard cresceu servindo muitas instituições 
conhecidas no mundo, como: a Universidade Estadual do Arizona e a Universidade Politécnica de Cingapura, etc. (Figura 5.1).

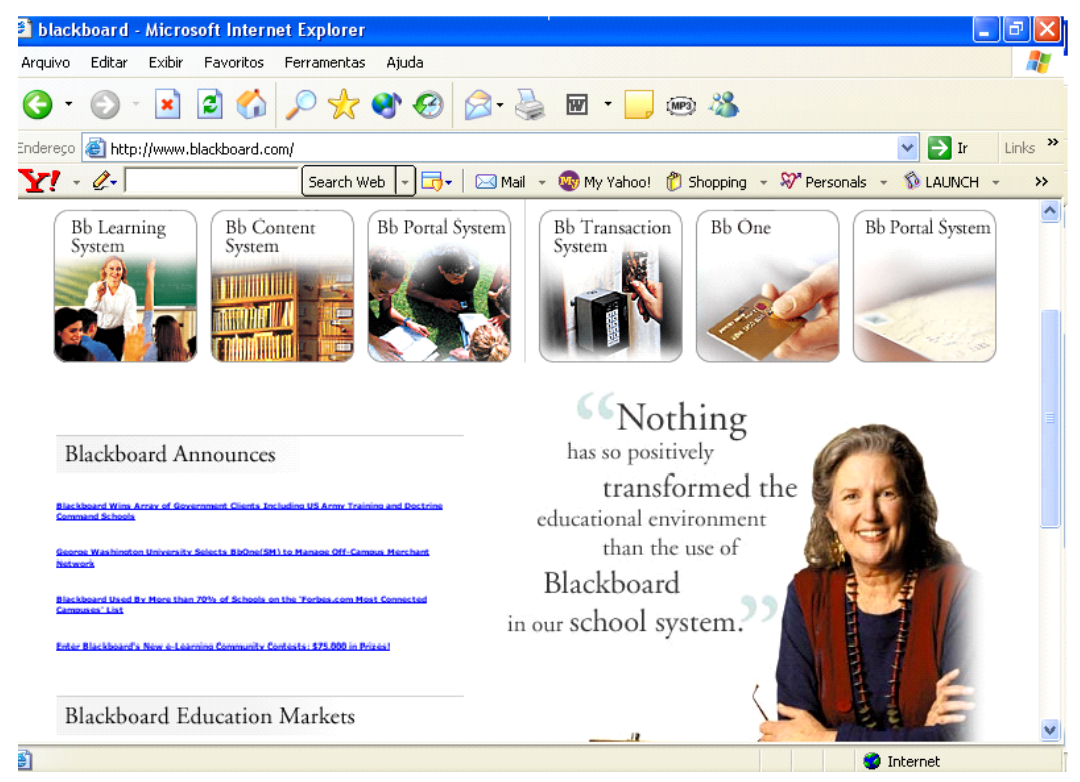

Figura 5.1: Página oficial do Blackboard em dez/04

\section{- First Class}

FirstClass é uma plataforma de comunicação que permite a construção e desenvolvimento de idéias em grupo, participação em fóruns de discussão, conferências, etc. (Figura 5.2). Apresenta-se como sendo uma poderosa ferramenta possuindo diversas plataformas síncronas e assíncronas, como: chats, e-mails, fax, agendas individuais e do grupo, etc. FirstClass integra também estas características com as ferramentas da web, permitindo que usuários que não tenham conhecimento da linguagem HTML criem suas páginas pessoais com facilidade e simplicidade. 


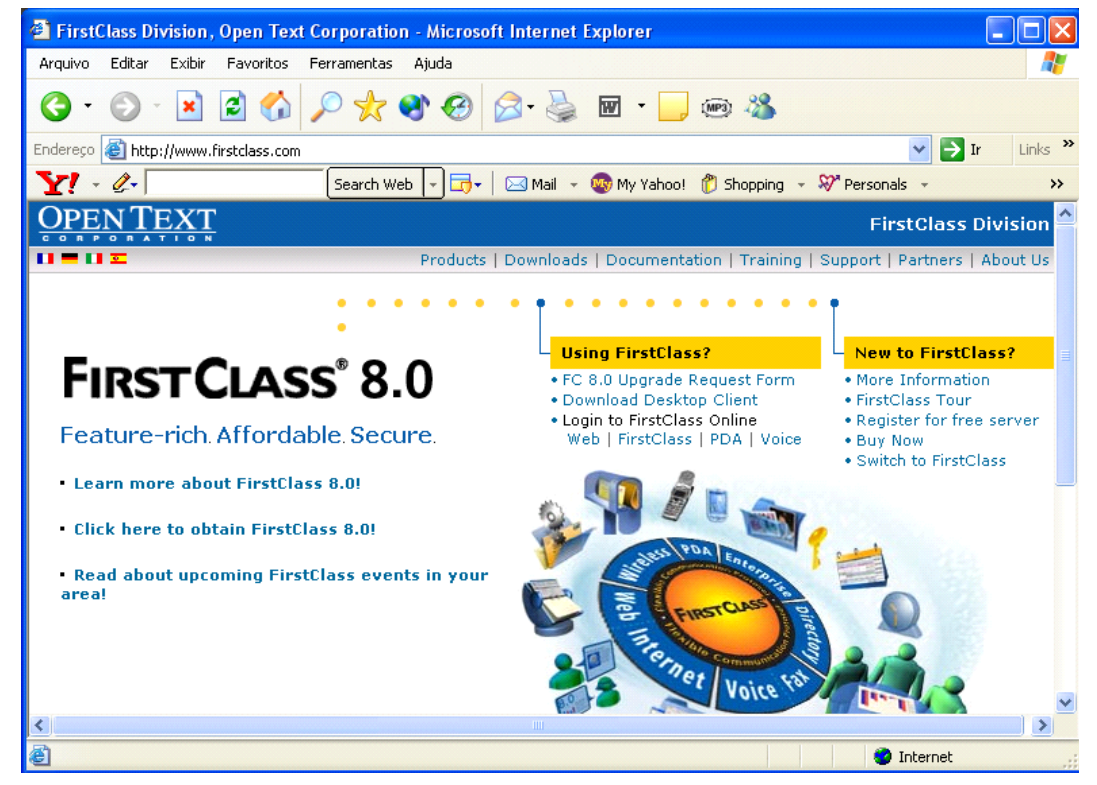

Figura 5.2: Página oficial do First Class em dez/04

\section{- Top Class}

É um sistema que pode ser utilizado para cursos ou treinamentos baseados na Internet ou para dar assistência às aulas tradicionais. Dentre suas principais opções, estão: lista de discussão, e-mails, testes de múlipla escolha e ferramentas para construção de cursos (Figura 5.3).

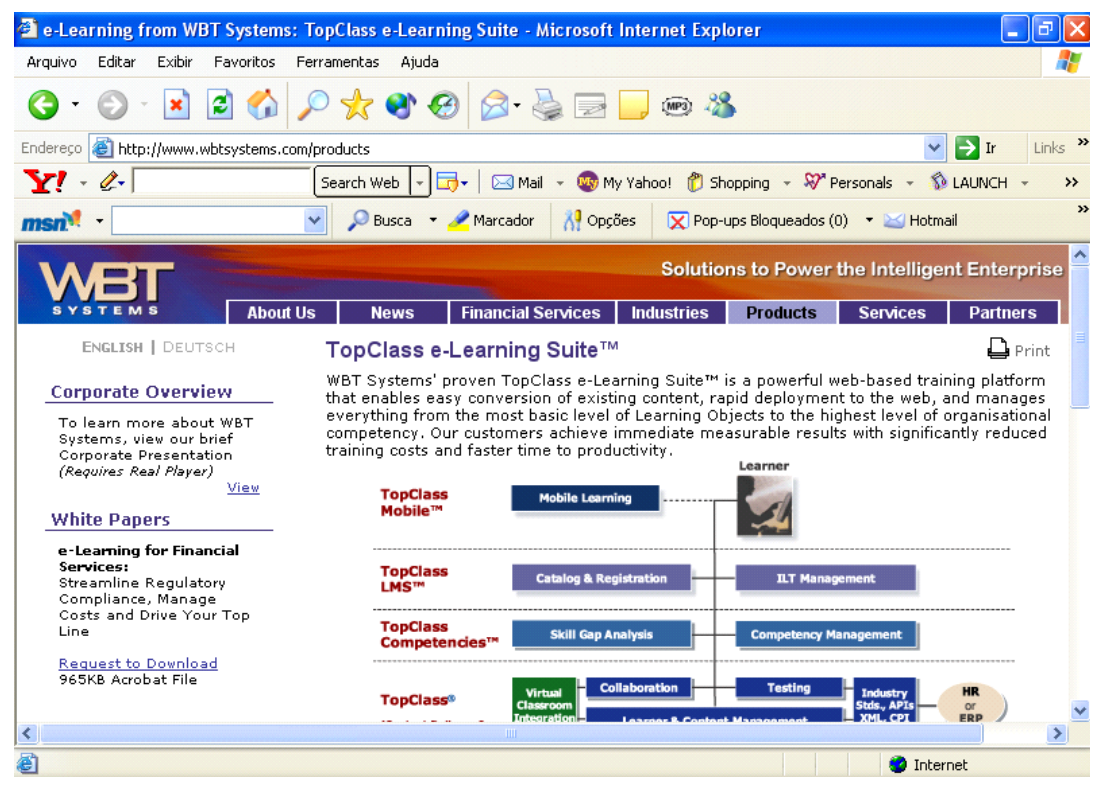

Figura 5.3: Página oficial do Top Class em dez/04

\section{- Lotus Learnig Space}

Segundo Souza (2001), era um sistema para implementação de ambientes cooperativos de ensino a distância desenvolvido em 1996 pelo Lotus institute. 
Dentre suas principais opções estavam: salas de "bate-papo", quadro de avisos e central de apoio a publicação de conteúdo, agenda, gerenciador de avaliação, etc. Este sistema mostrou ser uma poderosa ferramenta no auxílio de uso de tecnologias nas escolas e nas salas de aula durante oito anos (Figura 5.4). Por motivos financeiros fechou as portas de seu espaço de aprendizagem em 29 de outubro de 2004.

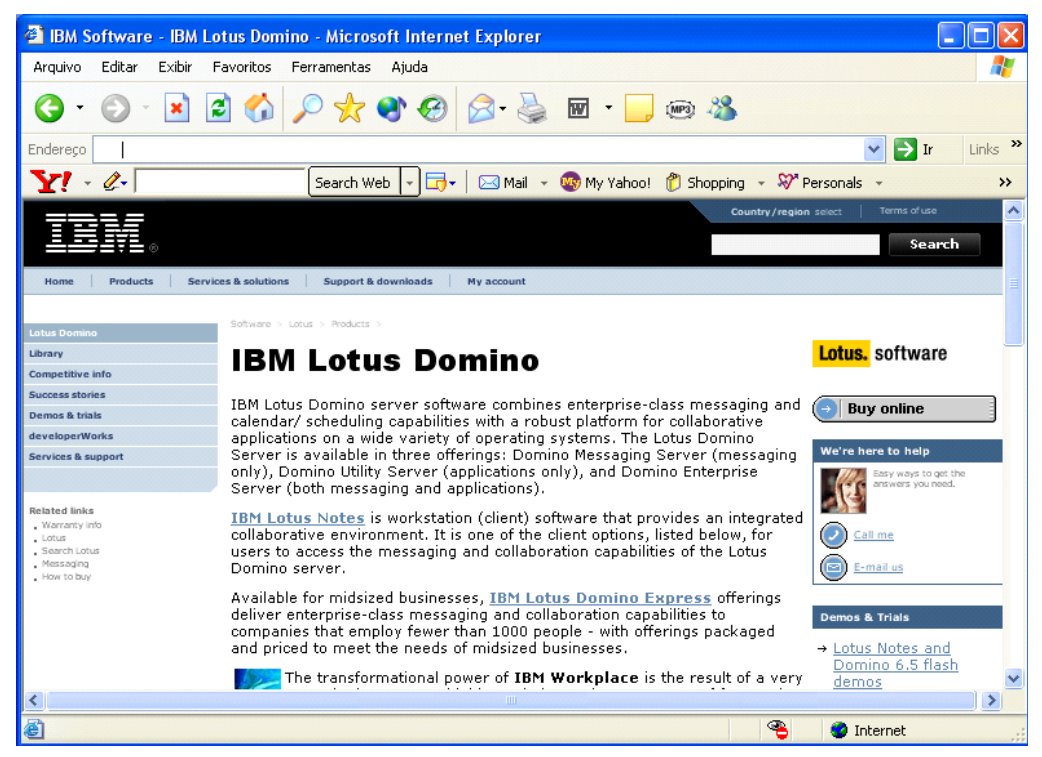

Figura 5.4: Página oficial do Lotus Learning Space em dez/04

\section{- WebCT}

O WebCT é um sistema para gerenciamento de cursos a distância ou semipresenciais, com o objetivo de criar, segundo Hutchins (2001) "uma coleção inovativa de ferramentas baseadas na web que facilitassem aos instrutores criar conteúdo que fosse simples para os alunos usarem". Segundo estudos realizados por Keegan et al. (2002), o WebCT possui já o maior grupo de clientes no mundo do ensino superior. Dispõe de uma rede de Sistemas de Gestão de cursos em mais de 2500 instituições, em 81 países de todo o mundo (Figura 5.5). 


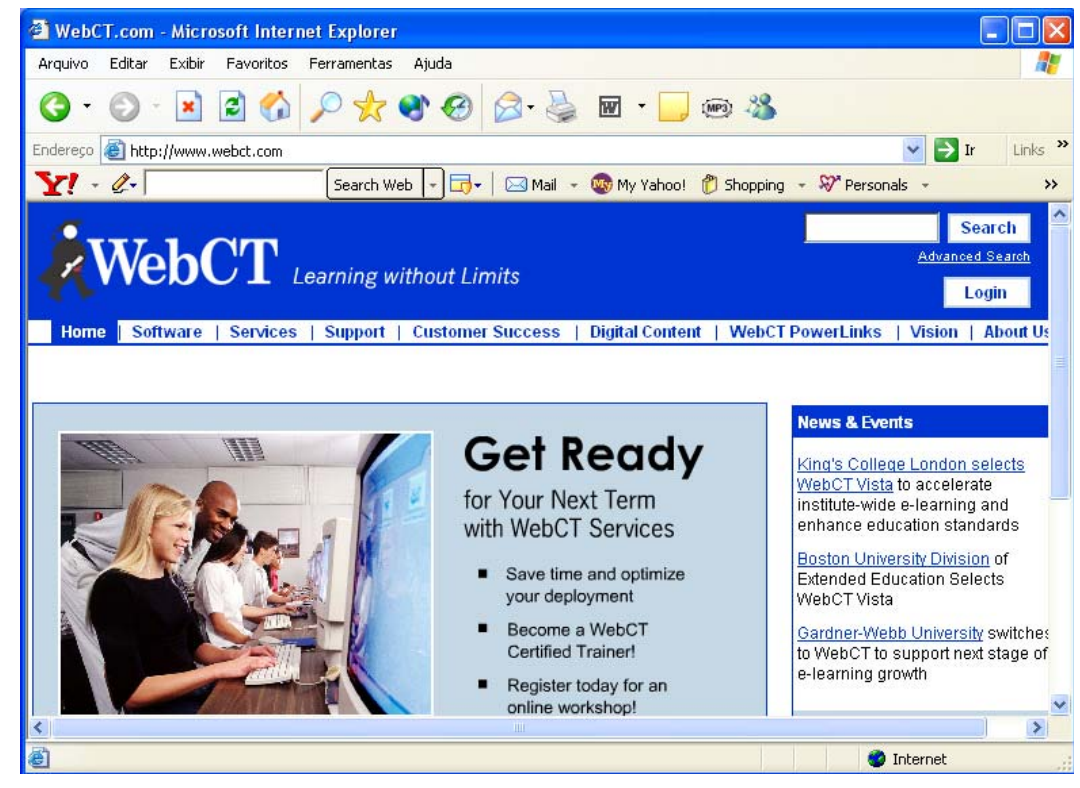

Figura 5.5: Página oficial do WebCT em dez/04

Dentre outras coisas, o WebCT fornece ferramentas de auto-avaliação e possibilita a colocação de questionários e trabalhos on-line. A estrutura do WebCT também fornece um enquadramento que não impõe uma pedagogia específica. Oferece comunicação síncrona (chat) e assíncrona (e-mail, lista de discussão). No WebCT os tutores podem ver, por exemplo, quais as páginas que foram consultadas pelos estudantes e com que freqüência os alunos entram no sistema.

As principais vantagens do uso do WebCT são: versatilidade, incentivo à participação, feedback, contato com os recursos da informática e o fato de favorecer e se adequar aos vários estilos de aprendizagem, podendo o aluno personalizar seu estudo. Segundo Hutchins (2001), a interface que esse recurso proporciona é bastante simples, tanto para o instrutor construir o curso e gerenciá-lo como para os alunos aprenderem e interagirem.

Apesar de possuir uma configuração padrão, permite também que o usuário configure a aparência das páginas do curso individualmente, em termos de cor, imagens de fundo e formatação de fontes. Além de permitir a publicação do conteúdo do curso, como foi dito, possui ferramentas para facilitar a comunicação aluno-professor e aluno-aluno. Dentre elas, pode-se citar: agenda, gabarito, chat e fórum. 
Segundo Souza (2001), um curso no WebCT está organizado em torno de uma página principal, com ligações para componentes de conteúdo do curso, como páginas do conteúdo em si, além de ferramentas de apoio, correio eletrônico, auto-avaliação e glossário. O sistema proporciona diferentes visões do curso, dependendo da classe do usuário (administrador, designer, monitor ou aluno). O WebCT teve licença adquirida pelo Centro de Computação Eletrônica (CCE) da Universidade de São Paulo (USP) para servir como ferramenta complementar aos cursos presenciais até dezembro de 2004. Na Figura 5.6 pode ser observada a página do WebCT na USP.

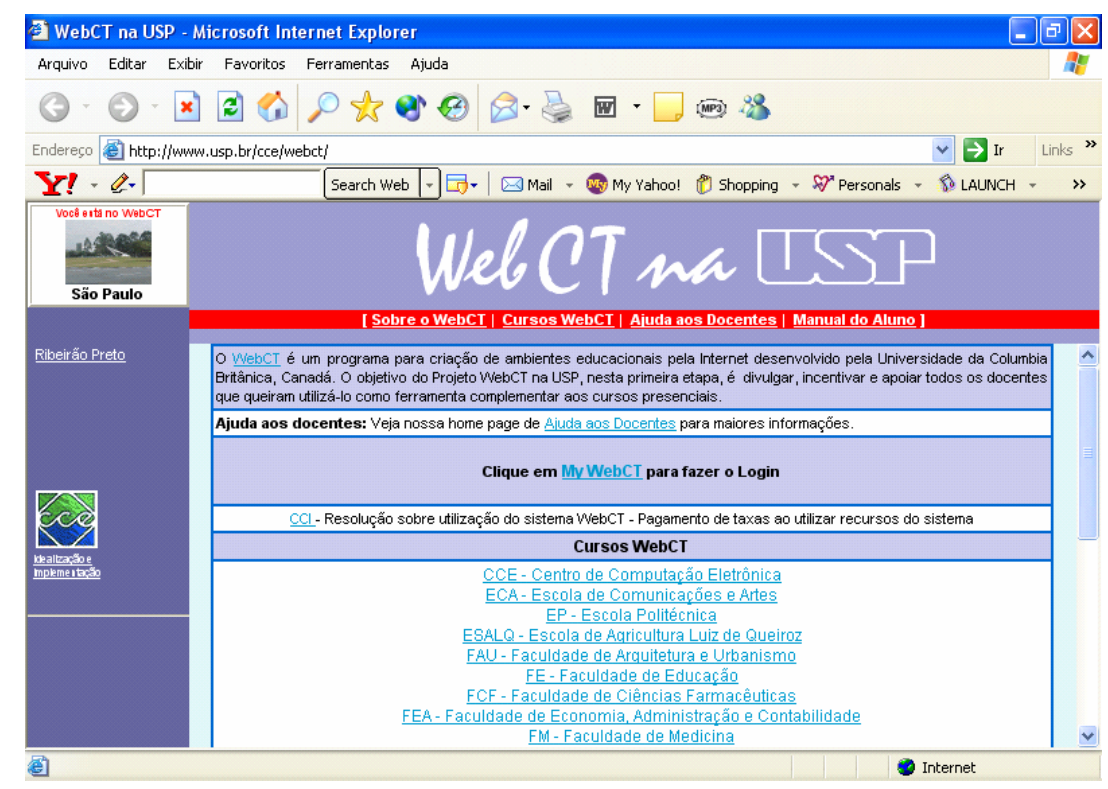

Figura 5.6: Página inicial do WebCT no campus de São Carlos da Universidade de São Paulo em dez/04

O Ambiente Virtual de Aprendizagem mais utilizado na Europa (Keegan et al., 2002) e bastante utilizado no Brasil, e que também será o utilizado para este trabalho pelo fato deste ser o sistema adotado pela USP, é o WebCT. Com o auxílio desse sistema de gerenciamento procurou-se desenvolver nesta pesquisa um ambiente de aprendizagem com caráter semipresencial. Através da Figura 5.7 pode-se observar a página da disciplina utilizada como estudo de caso desta tese. 


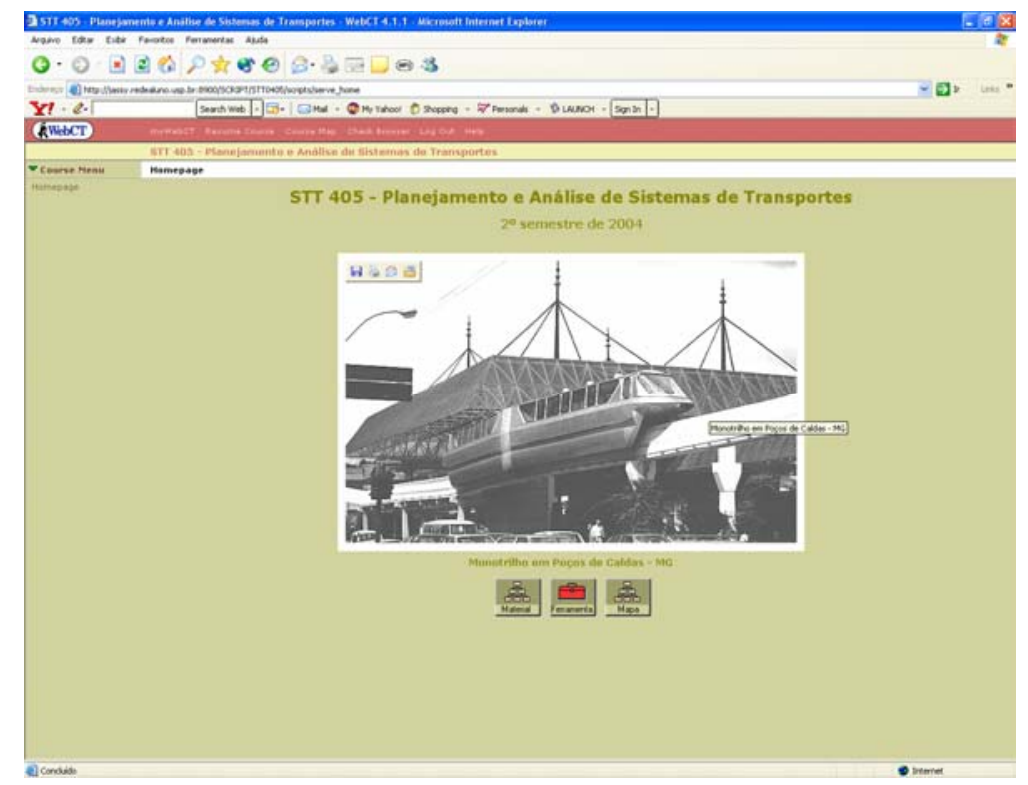

Figura 5.7: Página inicial do WebCT da disciplina em estudo: "Planejamento e Análise de Sistemas de Transportes" em dez/04

\section{- Col}

O Curso On Line (Col) é um sistema para criação e utilização de ambientes educacionais pela Internet, desenvolvido por um grupo de pesquisadores do Laboratório de Arquitetura e Redes de Computadores (LARC) da Escola Politécnica de São Paulo (Figura 5.8). Este sistema oferece o suporte necessário para organização de conteúdo, trabalhos, teste, FAQ (Frequently Asked Questions) automático, lista de discussão, etc. O Col está à disposição de toda comunidade USP e uso geral ou como apoio aos cursos presenciais da Universidade.

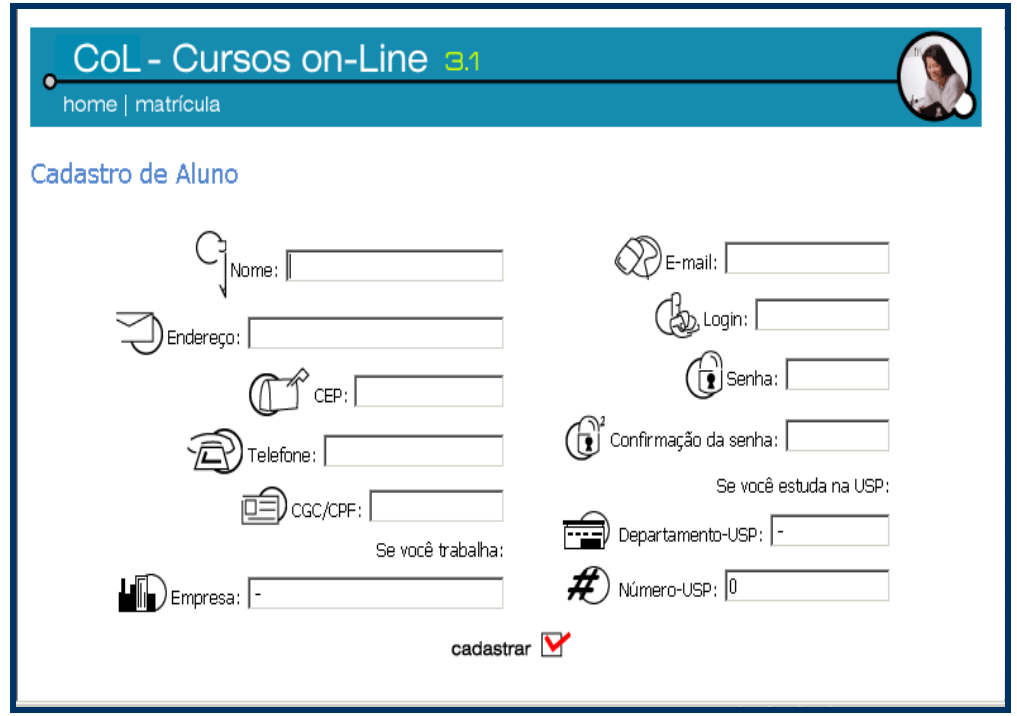

Figura 5.8: Página inicial do Col em mar/05 


\section{MÉTODO DO TRABALHO}

Neste capítulo é apresentada a metodologia de trabalho, onde se discute a proposta para que seja realizada a melhoria no processo de ensinoaprendizagem. Nesta mesma seção, é também apresentado o método de coleta e de avaliação dos dados utilizados no projeto.

Para tanto, pretende-se:

- Utilizar uma metodologia b-learning;

- Empregar uma abordagem construtivista;

- Incitar o aluno a buscar seu conhecimento através da pesquisa e explorando a Internet;

- Complementar a metodologia tradicional com a inserção de algumas alternativas pedagógicas, tais como:

- Implementação do conteúdo de uma disciplina em um CD;

- Baseado nos Modelos de Aprendizagem de Kolb e Felder e Silverman;

- Desenvolver um ambiente educativo na Internet;

- Realizar trabalhos em grupo;

- Estimular o aluno a explorar a Internet;

- Incentivar a pesquisa.

- Utilizar como técnica de coleta de dados:

- Testes de conhecimento;

- Provas; 
- Histórico de desempenho dos alunos;

- Técnica de seminários;

- Registros fornecidos pelo WebCT.

- Avaliar os dados através de métodos:

- Qualitativos;

○ Quantitativos.

Em síntese, a metodologia sugerida para a execução deste trabalho baseia-se em propor que alunos do curso de graduação em Engenharia Civil entrem em contato com novas formas de ensino-aprendizagem, criando, desta forma, uma aprendizagem individual e interativa. Nesse sentido, busca-se complementar o paradigma tradicional, apresentando uma proposta que conduza a uma aprendizagem permanente e individual, de maneira a provocar uma mudança no comportamento profissional do futuro engenheiro.

Deseja-se ainda que o aluno integre-se a uma educação que privilegie uma abordagem construtivista de aprendizagem, desenvolvendo no mesmo, habilidades exigidas pelo atual e competitivo mercado de trabalho, tais como: criatividade, raciocínio crítico, caráter integrador na dinâmica das relações, capacidade para enfrentar situações novas com criatividade, iniciativa na tomada de decisões, etc.

A metodologia proposta será testada a partir de uma experiência realizada com a disciplina "Planejamento e Análise de Sistemas de Transportes". Esta é oferecida aos alunos do terceiro ano do curso de Engenharia Civil da Escola de Engenharia de São Carlos e seu programa é dividido em nove módulos, como segue:

Módulo 1 - Transporte e sociedade

Módulo 2 - Análise de sistemas de transporte

Módulo 3 - Demanda por transportes

Módulo 4 - Custos de transporte

Módulo 5 - Oferta de transportes

Módulo 6 - Equilíbrio entre demanda e oferta

Módulo 7 - Tarifação em transporte 
Módulo 8 - Impactos ambientais

Módulo 9 - Avaliação de projetos de transporte.

Em anos anteriores está disciplina era normalmente ministrada pelos métodos tradicionais de ensino, seguindo o conteúdo citado acima, contido numa apostila desenvolvida por um professor do Departamento de Transportes da Escola de Engenharia de São Carlos.

Para atender às necessidades exigidas pelo competitivo mercado de trabalho pretende-se nesta pesquisa, modificar o paradigma tradicional com alternativas pedagógicas diversas, tendo como base os fundamentos do construtivismo, de modo a aprimorar o processo de ensino-aprendizagem.

\subsection{Alternativas Pedagógicas}

Hoje existem diversas propostas de trabalho que auxiliam o aluno no desenvolvimento de habilidades como: criatividade, flexibilidade, autonomia para tomada de decisões, trabalho em equipe, entre outros. Essas novas habilidades transformam o aluno não em um profissional com características de reprodutor fiel dos parâmetros vigentes da sociedade, mas num profissional com um diferencial que certamente estará pronto para enfrentar o competitivo mercado de trabalho. É também com este objetivo que, nesta pesquisa, foram introduzidos na metodologia tradicional de ensino algumas "alternativas pedagógicas", de forma a não apenas melhorar o processo de ensinoaprendizagem, mas também entregar à sociedade um profissional com 0 diferencial que ela espera.

\subsubsection{Implementação do conteúdo do curso em CD}

A implementação ou a produção de um $C D$ que abranja todos os requisitos pedagógicos é uma tarefa muito complexa. Ela envolve um número de etapas importantes como as seguintes, parcialmente extraídas dos trabalhos de Gonzalez et al. (1999), Barbuzza e Castro (1998) e Gonzalez (2000):

a) Preparar o conteúdo do curso

b) Estruturar e organizar o curso 

c) Criar recursos multimídias
d) Integrar os sistemas de mídias.

Nesta pesquisa, a autora elaborou um CD (Figura 6.1) com todo o conteúdo (nove módulos) da disciplina em questão. A idéia foi transformar os tópicos da apostila utilizada até então pela disciplina, numa forma de aprendizagem mais dinâmica, fornecendo o CD aos alunos no primeiro dia de aula.

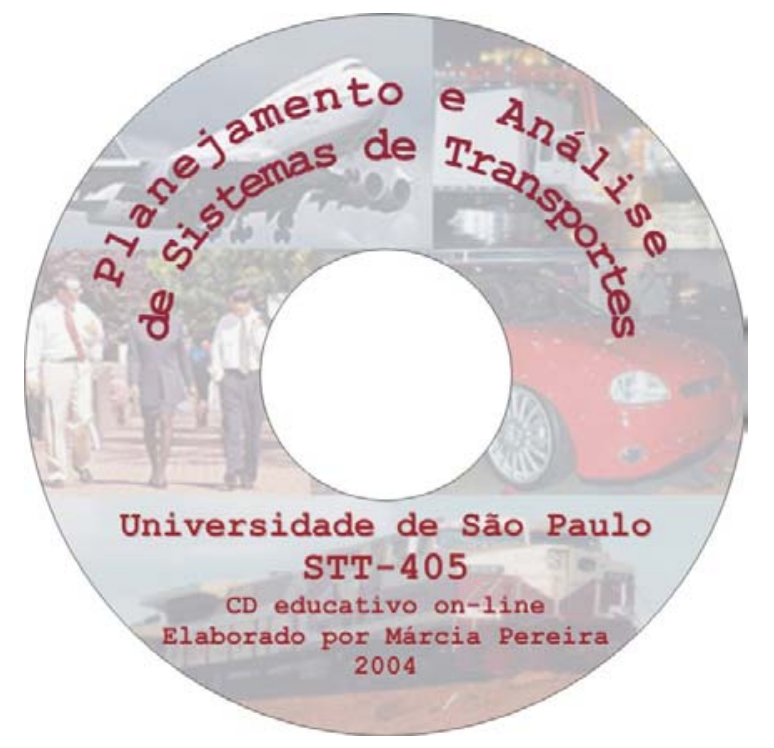

Figura 6.1: Rótulo do CD desenvolvido para a disciplina "Planejamento e Análise de Sistemas de Transportes"

Cada uma das etapas para a produção do $C D$ apresentadas anteriormente foi desenvolvida usando métodos, ferramentas e recursos dos mais variados. Desta forma, o CD não conteve apenas o material da apostila em si, mas exemplos com histórias narradas, imagens, sons, vídeos, etc. que foram combinados com a utilização do software Flash. As características principais de cada uma das etapas são brevemente descritas a seguir.

\section{a) Preparar o conteúdo do curso}

Nesta etapa, a proposta é descrever o conteúdo do curso de maneira clara, concisa e com uma certa ordem pedagógica para compreensão do assunto, de forma que o aluno seja incentivado a passar para a etapa seguinte, até o final da disciplina. Segundo Gonzalez (2000), o conteúdo pode ser apresentado de diferentes formas, como ilustrado na Figura 6.2. 


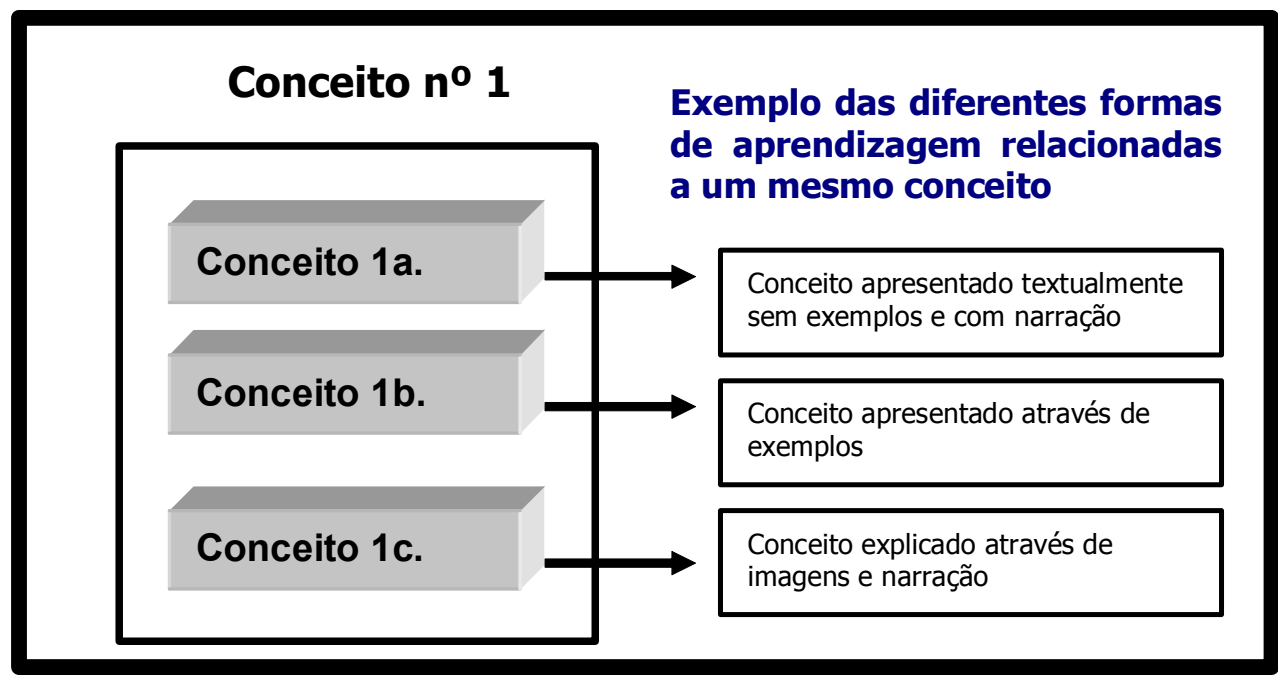

Figura 6.2: Diferentes formas de apresentar um conceito. Fonte: adaptada de Gonzalez (2000).

O corpo básico do CD para este trabalho de pesquisa foi composto por: conceitos, exemplos, narrações e vídeos. Isso foi desenvolvido para cada módulo da disciplina de Planejamento e Análise de Sistemas de Transportes.

Nesse sentido, segundo Lima (2002), para a melhoria da atratividade e na tentativa de sensibilizar a maior quantidade possível de sentidos dos alunos, além de textos, gráficos e animações, cada "página" ou "slide" do CD tem uma narração do que está sendo demonstrado naquele momento. Por outro lado, se o aluno tiver uma facilidade maior de memorização visual e achar interessante não executar a narração, isso também é permitido.

Esse pequeno exemplo é uma verdadeira aplicação da interação do aluno com o processo de ensino-aprendizagem, de acordo com suas características e necessidades pessoais. Ter o controle sobre o acesso ao material é um fator fundamental da interação do aluno com o material contido no CD. Apesar dele permitir uma navegação completamente livre pelo seu conteúdo, no entanto, foi estabelecida uma ordem pedagógica para a compreensão do assunto, que pode ser observada pela Figura 6.3, que mostra a "página" do menu do CD. 


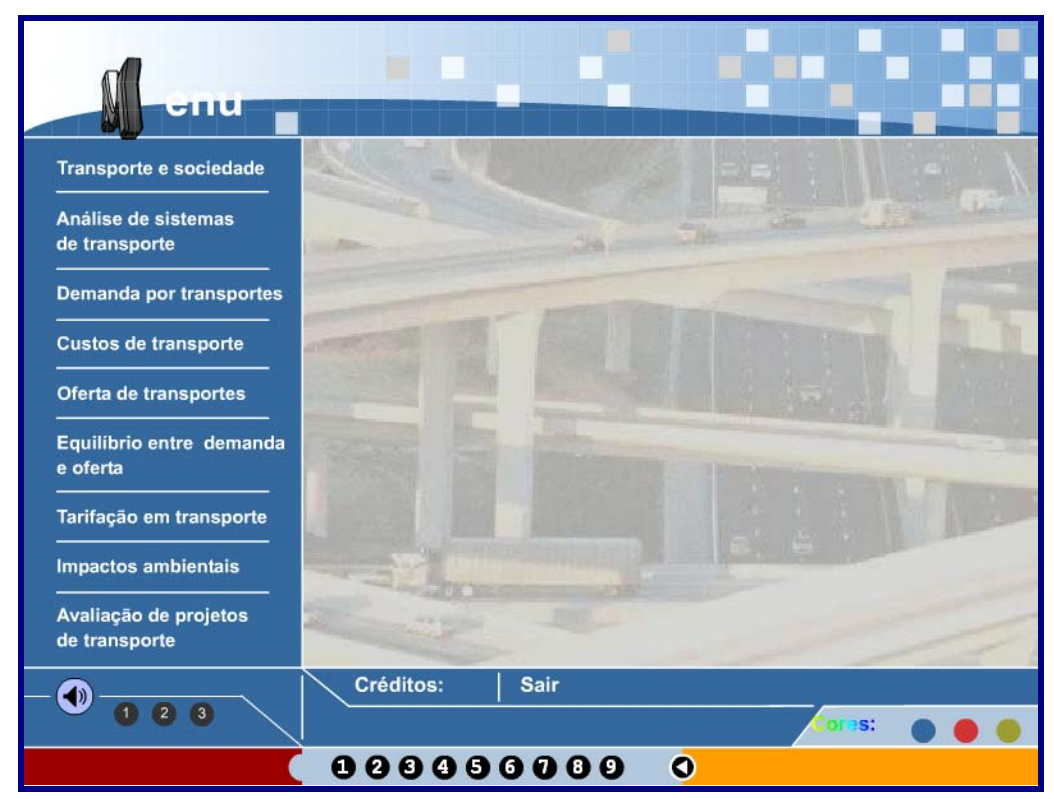

Figura 6.3: Página principal contendo o menu do CD

Além do conteúdo básico da disciplina, o aluno também tem acesso a links que podem levá-lo a navegar pela Internet em busca de outras informações, como é o caso da técnica Redes Neurais Artificiais, que foi apresentada ao aluno, ainda que de forma superficial, através de um link contido em uma das páginas do CD. Outra alternativa para o aluno é acessar um link que leva à resolução de exercícios contidos no software educativo WebCT.

Essa flexibilidade, fornecida pelo ambiente do CD e caracterizada pelo fato deste poder ser percorrido por diferentes caminhos, é a característica utilizada neste trabalho de tese.

Cabe lembrar que este CD foi desenvolvido tomando-se o cuidado de atender às necessidades educacionais de todos os tipos de estudantes, utilizando-se, para isso, os modelos de aprendizagem desenvolvidos por Kolb (1984) e Felder e Silvermann (1988). A aplicação desses modelos para a concepção do CD será vista no capítulo 07 .

\section{b) Estruturar e organizar o curso}

Segundo Gonzalez (2000), a proposta para se estruturar e organizar um curso, é dividí-lo em:

- Sumário: apresenta o índice geral do curso (Ver Figura 6.3). 
- Introdução geral do curso: apresenta uma breve explicação sobre o conteúdo do curso para que o aluno fique ciente do que pode dele esperar e sobre o que irá tratar.

- Desenvolvimento: composto por conceitos básicos, exemplos e exercícios. Aqui também entram os vídeos e animações desenvolvidos no CD.

- Avaliação: destinada a testar como transcorreu o processo de ensino-aprendizagem do aluno. Esta avaliação pode ser presencial ou à distância, com o auxílio do software WebCT, por exemplo.

\section{c) Criar recursos multimídia}

Segundo Gonzalez (2000), em multimídia existem cinco maneiras de elaborar e transmitir mensagens. Pode-se escrever, ilustrar, ouvir, animar e interagir. Entretanto, esses recursos precisam ser bem utilizados para não sobrecarregar a visão e audição do usuário e não desviá-lo do objetivo.

Nesta etapa foi fundamental a participação de especialistas experientes nas diferentes mídias, na sincronização de vídeo e som, etc., para a produção dos materiais correspondentes. Neste caso, esta pesquisa contou com a infraestrutura do Centro de Tecnologia Educacional para Engenharia (CETEPE) da Escola de Engenharia de São Carlos. Foram realizadas mais de 700 narrações (feitas pela própria autora da pesquisa), construção de desenhos para as animações e sua edição, contando sempre com a ajuda especializada de funcionários do CETEPE.

\section{d) Integrar os sistemas de mídias}

Nesta etapa, para que a integração seja possível é necessário, segundo Barbuzza e Castro (1998), estabelecer uma sincronização entre os diferentes elementos utilizados, especificando as relações espaciais e temporais entre eles. Trata-se de um processo com certo grau de complexidade, onde a autora teve o trabalho de sincronizar cada narração com sua devida animação. Esta etapa foi realizada com recursos do software Flash. 
Deve-se lembrar que todas as etapas foram elaboradas tendo em vista o objetivo de proporcionar uma aprendizagem mais dinâmica e atrativa para os alunos.

\subsubsection{Ambiente desenvolvido na Internet}

Em paralelo à implementação do conteúdo do curso em $C D$, os alunos da disciplina Planejamento e Análise de Sistemas de Transportes tinham também acesso a um ambiente na Internet, relacionado à disciplina.

Para a construção desse ambiente, as etapas são as mesmas seguidas para a implementação do conteúdo em CD, acrescentando apenas a etapa "Planejar o processo interativo", já que uma das desvantagens de trabalhar com o CD são as limitações de interação.

As funcionalidades de interação disponíveis são geralmente representadas pelos fóruns, chats, e-mails, lista de discussão, etc., embora nem todas as instituições utilizem todos esses serviços. Segundo Gonzalez (2000), fazendose uso de alguns desses recursos já é possível atingir um nível adequado de interatividade entre os alunos e entre professor e alunos. Essa etapa se caracteriza, segundo o mesmo autor, na forma mais poderosa de provocar a motivação disponível em uma apresentação multimídia, fato que criou um estímulo para que a Internet também fosse incluída nessa metodologia.

Neste trabalho utilizou-se ainda, de forma intensa, recursos de e-mail para a interação aluno/aluno, aluno/monitora, aluno/professor e monitora/professor. A monitora da disciplina, neste caso, era a própria autora do trabalho.

Conforme visto em capítulos anteriores, a implementação de uma aprendizagem semipresencial (b-learning), como é o caso desta pesquisa, pode ser feita através de Ambientes Virtuais de Aprendizagem, dentre os quais o WebCT, que foi aqui utilizado. A construção do ambiente da disciplina na Internet (WebCT) iniciou-se com o trabalho de mestrado de Souza (2001), o qual foi adaptado pela autora desse trabalho para o curso em questão. 
Segundo a mesma autora, docentes e alunos devem interagir com o curso através de ambientes diferentes e para realizar atividades distintas. Os professores interagem com a ferramenta para a preparação do curso e os alunos através das páginas do curso.

No caso do WebCT, segundo Souza (2001), é permitido ao professor:

- Ver, compilar e editar informações sobre os alunos;

- Incluir, retirar ou editar as notas dos alunos;

- Fornecer informações sobre o progresso dos alunos, quais as páginas por eles visitadas, as ferramentas utilizadas, etc.;

- Fornecer informações estatísticas sobre as páginas do curso, etc.

Já os alunos possuem um conjunto de ferramentas que podem ser disponibilizadas pelos professores, dependendo do objetivo do curso. A título de exemplo, algumas delas podem ser observadas na Tabela 6.1, adaptada de Souza (2001).

Tabela 6.1: Algumas das principais ferramentas do WebCT (ícones adaptados) Fonte: Adaptado de Souza (2001).

\begin{tabular}{|c|c|}
\hline Ícones & Descrição \\
\hline 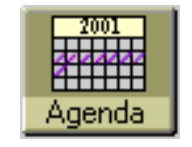 & $\begin{array}{l}\text { Avisos importantes dados pelo docente, tais como de prova, } \\
\text { trabalho e aulas especiais podem ser consultados clicando } \\
\text { neste item. }\end{array}$ \\
\hline 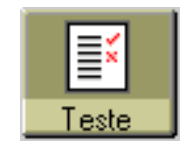 & $\begin{array}{l}\text { Permite o acesso a testes que o aluno pode responder, } \\
\text { enviar e ter o retorno imediato de seu desempenho. }\end{array}$ \\
\hline 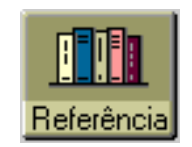 & $\begin{array}{l}\text { Este ícone leva a uma página preparada pelo docente, que } \\
\text { contém uma lista de links externos que contemplam o } \\
\text { assunto tratado no curso. }\end{array}$ \\
\hline 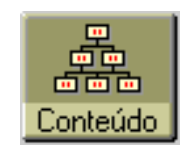 & Mostra o conteúdo do curso organizado em itens. \\
\hline
\end{tabular}

\subsubsection{Trabalho em grupo}

Cada vez mais se exige no mercado de trabalho o agrupamento de 
profissionais em equipes. Sabe-se que quando as pessoas trabalham em grupo, elas realizam mais. O trabalho em grupo, se iniciado na universidade, possibilita uma melhor formação do indivíduo, pois novas habilidades estarão sendo desenvolvidas. Desta forma, quando o profissional ingressa no mercado de trabalho, encontra-se apto a desenvolver atividades requeridas pela organização.

Uma das vantagens do trabalho em grupo é que não exige nenhuma infraestrutura extra ou recursos tecnológicos inovadores na instituição (Figura 6.4).

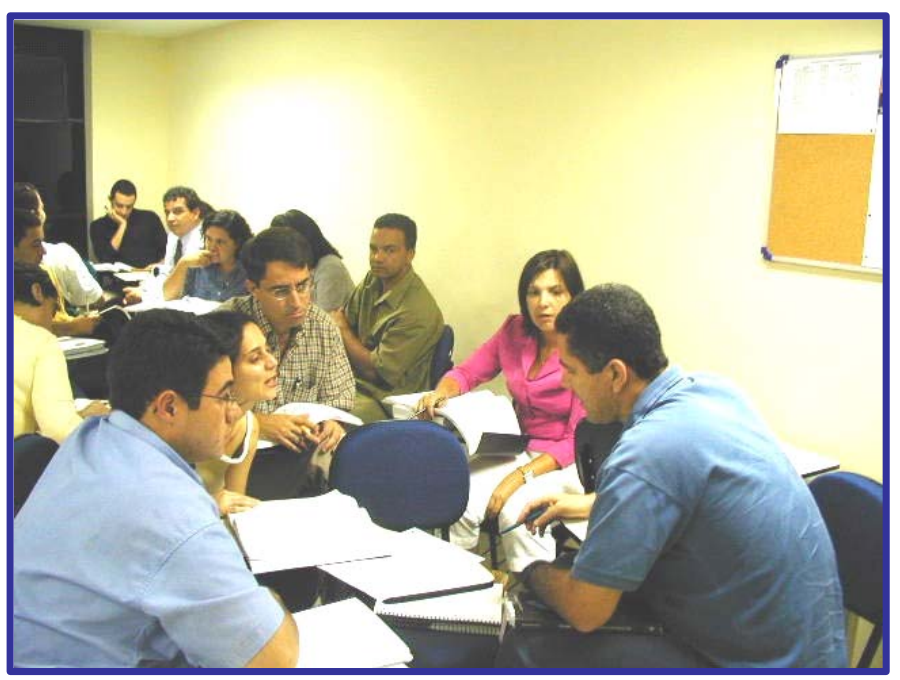

Figura 6.4: Exemplo de um trabalho em grupo

Segundo Colenci et al. (1998), o mercado de trabalho tem adotado a formação de equipes de trabalho como alternativa estrutural. Mudando a forma de trabalho, muda-se também o perfil do profissional que, neste caso, está passando de uma postura individualista para uma postura coletiva.

Nesse sentido, a principal razão para a formação de grupos de aprendizagem, segundo Colenci (2000), é a necessidade de aprender com os demais, de partilhar com os outros as idéias, sentimentos, de conseguir um melhor entrosamento com as pessoas e com o mundo.

Através dessa técnica, as pessoas entram em contato com visões de mundos diferentes, aprendem a socializar, a ouvir e dar opiniões sobre determinado assunto a aceitar outras sugestões, a formar uma mentalidade de grupo, a 
concentrar a atenção, a ter iniciativa, entre outros.

Almeida (1973) cita que o trabalho em grupo, em geral, torna a atividade mais agradável, possibilita a realização de uma atividade comum, com objetivos comuns, possibilitando o enriquecimento de experiências e vivências.

Entretanto, sabe-se que as atividades grupais não devem ser iniciadas abruptamente. É preciso que o professor prepare e planeje as atividades. Nesta pesquisa, essa alternativa pedagógica foi utilizada em duas ocasiões. Primeira, para a elaboração de seminários, onde a turma $(n=40)$ foi dividida em oito grupos. Segunda, na etapa de preparação e avaliação da prova, etapas essas que serão melhores discutidas no item "Avaliação dos dados".

\subsubsection{Pesquisa}

A atitude da pesquisa é o cerne do aprender a aprender. A pesquisa é o meio para despertar e motivar a atitude de investigação, questionamento, criatividade e curiosidade crítica, entre outros fatores que irão fazer com que o próprio aluno chegue ao conhecimento (Colenci, 2000).

Através desta alternativa pedagógica o aluno pode ser capaz de buscar novos conhecimentos, não se tornando um profissional obsoleto frente às mudanças decorrentes de novas técnicas e tecnologias. Diante deste contexto, neste trabalho, ainda com o propósito de melhoria no processo de ensinoaprendizagem, adotou-se esta estratégia em duas ocasiões. Primeiro, no incentivo ao uso da Internet e, segundo, para o desenvolvimento de seminários. Cada um desses itens será brevemente descrito a seguir.

\subsubsection{Pesquisa à Internet}

Sabendo-se que uma das vantagens da Internet é a acessibilidade a fontes virtualmente inesgotáveis de assuntos para pesquisa, os alunos $(n=40)$ que cursaram a disciplina "Planejamento e Análise de Sistemas de Transportes" com o professor que também é o orientador deste trabalho, foram divididos em dois grupos, sem o conhecimento deles do grupo a que pertenciam. O primeiro deles, chamado "Grupo de Controle", exercia as atividades normais durante 
todo o curso. O segundo grupo, aqui chamado de "Grupo Experimental", além de exercer as atividades propostas no curso, recebia a cada final de módulo uma questão que o levaria à Internet. Nesta questão, o aluno deveria pesquisar, utilizando-se da Internet, a relação do assunto estudado com algumas técnicas emergentes, como as Redes Neurais Artificiais, por exemplo, e com o tema atual Desenvolvimento Sustentável. Dessa maneira, o "Grupo Experimental" estava sempre explorando a Internet na busca de conhecimentos e informações para responder à questão citada, tendo ainda, que informar ao professor a página da Internet visitada (vide Quadro 6.1).

Formule aqui uma questão dissertativa que associe o módulo estudado à técnicas emergentes, ou ao tema Desenvolvimento Sustentável, cuja resposta esteja disponível em uma página da Internet. Forneça o "endereço" da página e indique qual a resposta à questão formulada.

Quadro 6.1: Exemplo da questão dissertativa fornecida para metade da turma

Pretende-se através desta estratégia fazer com que o uso da Internet na pesquisa introduza um novo modo de lidar com a informação e com o conhecimento, causando, desta forma, um impacto direto no processo de ensino-aprendizagem. Uma análise deste subitem será feita no capítulo 08.

\subsubsection{Pesquisa para desenvolvimento de seminários}

Esta outra estratégia de utilização da pesquisa como forma de avaliação foi utilizada para fazer com que os quarenta alunos do curso entrassem em contato com técnicas emergentes, tais como: Redes Neurais Artificiais, Lógica Fuzzy, Autômatos Celulares, Sistema de Informação Geográfica, Simulated Annealing, Estatística Espacial, Algoritmos Genéticos e Avaliação Multicritério, sem alterar a grade curricular nem o tempo de sala de aula dedicado à disciplina.

Esta experiência foi realizada através do desenvolvimento de seminários abordados com os temas citados acima. Pode-se dizer que foram obtidos resultados bastante positivos com a utilização dessa alternativa pedagógica, no que diz respeito à busca de novos conhecimentos. Uma avaliação mais detalhada será também feita no capítulo de análise dos resultados. 
Com a introdução dessas alternativas pedagógicas no método de ensino, pretende-se uma melhoria no processo de ensino-aprendizagem dos alunos que se submeteram a essa experiência.

\subsection{Seleção dos Métodos / Técnicas de Coleta de Dados}

Existem diferentes métodos/técnicas para coleta de dados. Pode-se utilizar, por exemplo, diários, questionários, registro em vídeos, registro automático de recursos, pesquisas domiciliares, pesquisas por telefone, dependendo sempre do objetivo do que se quer avaliar em particular (Carvalho, 1998).

No caso deste projeto, as técnicas de coleta de dados utilizados para avaliar a proposta de melhoria no processo de ensino-aprendizagem foram: testes de conhecimento, provas, histórico de desempenho de alunos, seminário e registro automático.

\subsubsection{Testes de conhecimento}

No decorrer do curso de Planejamento e Análise de Sistemas de Transportes foram elaborados, a cada módulo, testes de conhecimentos relacionados a cada tema. Estes testes visaram medir não somente a transferência de conhecimentos, porém, mais importante do que isso, a construção do conhecimento executado pelo aluno durante o curso. Para isso, a turma de 40 alunos foi dividida em dois grupos sem o conhecimento dos próprios alunos. $\mathrm{O}$ objetivo era fazer com que a metade da turma recebesse seis questões objetivas de cada módulo e a outra metade, além dessas, recebesse uma questão de cunho dissertativo e que fizesse o aluno buscar novos conhecimentos não vistos em sala de aula. Um exemplo dessa questão pode ser vista no Quadro 6.1.

Ao final do curso, todos os quarenta alunos responderam a questão mostrada no Quadro 6.2, com o objetivo de avaliar se os alunos que participaram da questão dissertativa conseguiram absorver algum conhecimento. A avaliação desta questão será avaliada posteriormente. 
Você já ouviu falar da técnica Redes Neurais Artificiais ou do tema Desenvolvimento Sustentável? Se sim, descreva em no máximo dez linhas o que sabe sobre cada um, relacionando com planejamento de transportes.

Quadro 6.2: Exemplo da questão fornecida a todos os alunos no final do curso

\subsubsection{Provas}

Durante o decorrer do curso, foram elaboradas duas provas aos alunos com caráter exclusivamente prático (exercícios). A primeira prova foi aplicada nos moldes dos métodos tradicionais de ensino. Já a segunda, foi elaborada de maneira diferente; feita pelos próprios alunos. Para isso, a turma foi dividida em oito grupos de cinco alunos cada. Cada grupo (A, B, C...H) ficou responsável, sete dias antes da prova em sala de aula, pela elaboração de cinco questões práticas referentes aos módulos que seriam cobrados na prova ( $A 1, A 2, \ldots A 5)$. Ao final, o professor contava com um conjunto de quarenta questões, as quais foram previamente examinadas e aprovadas pelo professor. No dia do exame formal, cada aluno recebeu duas, das quarenta questões, para resolver. Porém, cada prova foi cuidadosamente elaborada de forma que nenhum aluno do grupo que elaborou a questão resolveria a mesma na prova. Dessa maneira as provas foram elaboradas de forma única e individual. O modelo de uma prova encontra-se no Anexo A deste trabalho. Já a avaliação dessas provas será discutida no capítulo 08 .

\subsubsection{Histórico de desempenho dos alunos}

Outra forma de avaliação a ser feita nesta experiência será a comparação de desempenho dos alunos que cursaram essa mesma disciplina, com os mesmos professores, no decorrer dos oito últimos anos, ao longo dos quais o processo de ensino-aprendizagem era realizado através do paradigma tradicional. Posteriormente, será feita uma comparação com as duas turmas de 2004 (a que continuou utilizando a abordagem tradicional, com a turma que realizou sua aprendizagem através do novo paradigma proposto) e ainda uma comparação entre a turma dos grupos de Controle e Experimental. 


\subsubsection{Seminário}

Segundo Kuri e Giorgetti (1998), o seminário é o estudo intensivo de um tema em reuniões planejadas e desenvolvidas em pequenos grupos, sob a orientação de um professor. É um método apropriado quando se pretende desenvolver habilidades intelectuais superiores por meio de métodos ativos, já que favorece a aprendizagem pela descoberta, construção do conhecimento e pensamento divergente.

Cada um dos oito grupos recebeu um tema que teria que conhecer e compreender, de forma a apresentar para o restante da turma, um mês depois e em quinze minutos, seus conceitos e aplicações na engenharia de transportes. Os temas abordados foram os mesmos mencionados no item 6.1.4.

O objetivo deste seminário, além de fazer com que os alunos tomassem contato com novas técnicas, era que tivessem a oportunidade de tomar decisões não somente no plano conceitual, como também na organização de sua própria aprendizagem, vivendo experiências de liderança, manejo de conflitos e outras dimensões da interação grupal. A avaliação foi feita de três formas: avaliação feita pelos alunos, auto-avaliação e uma avaliação feita pelo professor usando a metodologia da Taxonomia de Bloom (1956), que será vista no item 6.3.1.1.

\subsubsection{Registro automático}

Com a utilização do software educativo WebCT, pode-se obter resultados de participação dos alunos das páginas navegadas no software a partir do relatório de acompanhamento fornecido por ele.

Nestes relatórios, é possível observar também a data do primeiro e último acesso feito por aluno, o que permite ao professor fazer uma análise mais detalhada da participação dos alunos no WebCT. Por exemplo, pode ser visualizado quais alunos responderam ao primeiro exercício, ao segundo, e assim sucessivamente. Com o número total de hits, ou seja, o número de visitas dados em links do ambiente, pode-se ter uma idéia de como foi a 
navegação do aluno no site (Figura 6.5).

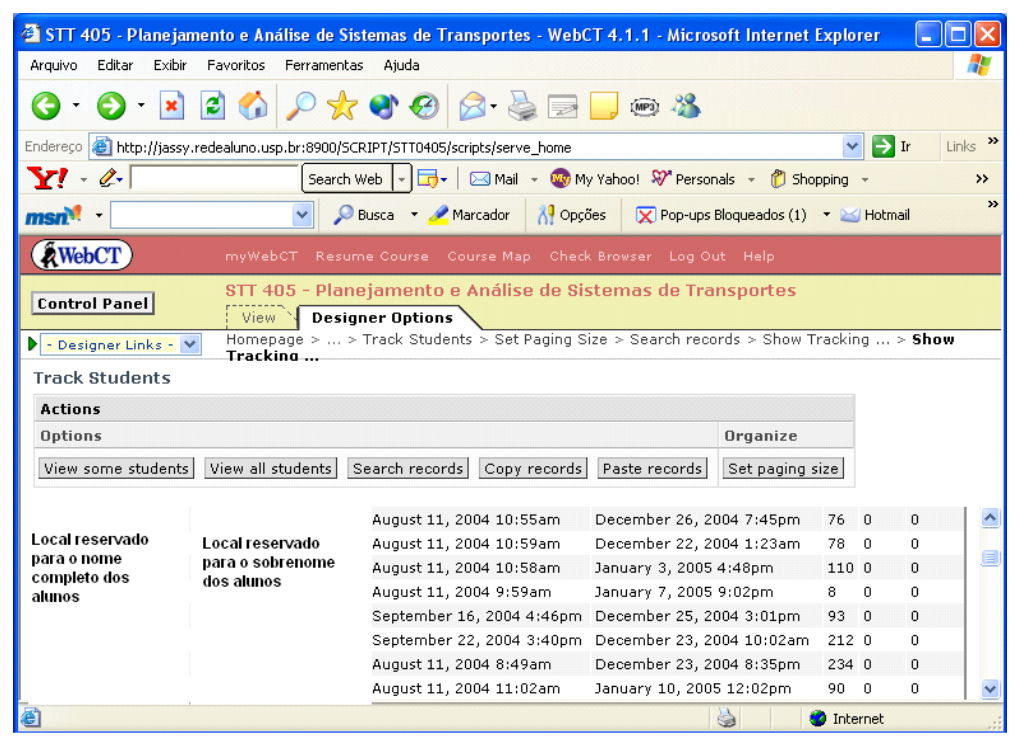

Figura 6.5: Relatório de acompanhamento dos alunos no WebCT (cujo nomes foram omitidos intencionalmente).

Diante do exposto, tanto a coleta como a avaliação dos dados, é uma tarefa didática que deve acompanhar passo a passo o processo de ensinoaprendizagem. Por meio delas, segundo estudos de Almeida et al. (2002) e Abreu e Masetto (1990), os resultados que serão obtidos no decorrer do trabalho conjunto do professor e dos alunos devem ser comparados com os objetivos, a fim de constatar progressos, dificuldades e reorientar o trabalho para as correções necessárias.

\subsection{Avaliação dos Dados}

Segundo Almeida et al. (2002) o compromisso essencial da avaliação, como parte do processo de ensino-aprendizagem, é favorecer a aprendizagem do aluno. Para isso, ela deve ser permanente (contínua durante todo o curso). Desta forma, segundo Pallof e Pratt (2002), a avaliação fornece aos professores uma possibilidade de mudar o rumo do curso se ele não estiver correndo de acordo com o programado. A avaliação, sendo executada apenas no final do curso (Avaliação Final), não mede a dinâmica e o ritmo de aprendizagem do aluno (Brookfield, 1995). 
Diante deste contexto, no caso desta pesquisa, fazer apenas a avaliação final em um curso on-line ou semipresencial (b-learning) é ignorar muitas das idéias importantes relacionadas à forma de aprender e ensinar. Os dados da coleta podem ser qualitativos e quantitativos (Cook e Reichardt, 1979; Marchionni, 1990; Fraser e Walberg, 1991; Smith e Mayes, 1996).

Segundo Fraser e Walberg (1991), pesquisas envolvendo métodos qualitativos e quantitativos têm trazido excelentes contribuições para temas voltados ao ensino, devido a riqueza de informações obtidas nestes. Contudo, para se avaliar a melhoria no processo de ensino-aprendizagem como um todo (professor, aluno e curso) as técnicas utilizadas foram divididas nesses dois métodos, como segue:

\subsubsection{Método qualitativo}

Segundo Almeida et al. (2002), os métodos qualitativos objetivam analisar e descrever as informações obtidas pela coleta de dados, permitindo incluir uma grande riqueza de percepções.

Isso será obtido através das respostas às questões dissertativas, das respostas de auto-avaliação feitas dos seminários, das respostas das avaliações feitas pelos alunos dos seminários e através das respostas dada pelo professor com a utilização do método de avaliação feito através da Taxonomia de Bloom.

Outra forma de avaliação através do método qualitativo seria quanto à proposta de utilizar o CD como forma de facilitar a aprendizagem. Isso pôde ser constatado através das respostas dadas aos alunos em uma das questões objetivas respondidas nos testes referentes a cada módulo. (Ver Quadro 6.3).

Apenas para nosso controle é importante saber como você acompanhou esse módulo

( ) Através das aulas e do CD

( ) Exclusivamente através das aulas

( ) Exclusivamente através do CD

( ) Utilizando mais o CD do que as aulas propriamente ditas

( ) Através das aulas mais do que utilizando o CD

Quadro 6.3: Questão objetiva referente a ajuda do CD na aprendizagem 


\subsubsection{Taxonomia de Bloom}

Bastante disseminada em vários países, essa classificação diferencia três tipos básicos de aprendizagem, em função dos resultados ou produtos a serem obtidos. A classificação de Bloom propõe três domínios educacionais: cognitivo (conhecimentos e habilidades intelectuais), afetivo (interesses, atitudes e valores) e psicomotor (habilidades motoras e manuais). Ela facilita a troca de informações sobre os planos de avaliação. Reportando-se à taxonomia, o professor terá condições para definir expressões imprecisas como: "O que o aluno realmente compreendeu?" (Bloom, 1956).

Em resumo, os professores encontram na taxonomia um modelo relativamente preciso para a análise de resultados educacionais na área cognitiva, que abrange memória, pensamento e solução de problemas.

Um sistema de classificação representa o ponto de partida de muitas das pesquisas educacionais. A estrutura da taxonomia, até o presente momento, está constituída de seis classes principais (Ver Tabela 6.2). Os tipos de habilidades que envolvem "compreender" e "formação de conceitos" estão incluídas nas quatro primeiras categorias e as habilidades que envolvem "criatividade" são a síntese e avaliação.

Observa-se que o que se pretende ao adotar a taxonomia de Bloom é classificar o comportamento esperado como resultado da participação do aluno em alguma unidade de ensino; não se pretende classificar metodologias de ensino, modo de relacionamento de professor/aluno ou diferentes tipos de materiais de ensino empregados, muito menos uma matéria específica. 
Tabela 6.2: Tabela contendo as 6 categorias ou níveis da Taxonomia de Bloom

\begin{tabular}{|l|l|}
\hline Categoria 01 - Conhecimento & $\begin{array}{l}\text { O aluno apresenta definições literais, afirma fatos } \\
\text { e regras. Fase da repetição. }\end{array}$ \\
\hline Categoria 02 - Compreensão & $\begin{array}{l}\text { O aluno não deve apenas repetir, mas } \\
\text { compreender o que aprendeu, pelo menos o } \\
\text { suficiente para afirmá-lo de outra forma. } \\
\text { Apresenta em palavras, informações contidas } \\
\text { numa figura ou gráfico. Fase da formação de } \\
\text { conceitos. }\end{array}$ \\
\hline Categoria 03 - Aplicação & $\begin{array}{l}\text { O aluno deverá resolver problemas diferentes dos } \\
\text { que já tenha visto. O problema deve ser novo. } \\
\text { Resolver problemas idênticos não é aplicação } \\
\text { mas sim conhecimento. Fase da formação de } \\
\text { conceitos. }\end{array}$ \\
\hline Categoria 04 - Análise & $\begin{array}{l}\text { O aluno deverá identificar as partes ou a estrutura } \\
\text { de um todo. Fase da formação de conceitos. }\end{array}$ \\
\hline Categoria 05 - Síntese & $\begin{array}{l}\text { O aluno deve expressar suas próprias idéias, } \\
\text { experiências e o produto enviado por ele será } \\
\text { diferente do produto de outros. Fase da } \\
\text { criatividade. }\end{array}$ \\
\hline Categoria 06 - Avaliação & $\begin{array}{l}\text { O aluno deve comparar dois produtos, justificar. } \\
\text { Fase da criatividade. }\end{array}$ \\
\hline
\end{tabular}

\subsubsection{Método quantitativo}

Segundo Almeida et al. (2002), os métodos quantitativos consistem basicamente na comparação sistemática de qualidades e permitem a análise estatística de relações. Assim sendo, numa turma que depende bastante da participação do aluno na experiência, a quantidade de vezes que o aluno acessou o site, por exemplo, torna-se material para a avaliação, ou seja, neste caso, serão utilizados os Registros Automáticos.

Outra forma de avaliação a ser feita nesta experiência, pelo método quantitativo, será a comparação de desempenho dos alunos que cursaram essa mesma disciplina através do Histórico de desempenho de alunos. Posteriormente, será feita uma comparação do desempenho através das médias das notas finais, das duas turmas de 2004; aquela que continuou utilizando a abordagem tradicional $(n=20)$, com a turma $(n=40)$ que realizou sua aprendizagem através do novo paradigma proposto (CD e Internet) e também entre os grupos Experimental e de Controle. 


\section{APLICAÇÃO DO MÉTODO}

Neste capítulo é apresentada a aplicação do método do trabalho, descrito no capítulo 06. O método foi aplicado, como já citado anteriormente, no nível de ensino universitário, composto por alunos do terceiro ano do curso de Engenharia Civil. A instituição selecionada foi a Escola de Engenharia de São Carlos da Universidade de São Paulo. Assim, a amostra participante foi constituída por quarenta alunos que freqüentaram a disciplina que trata de Planejamento de Transportes intitulada "Planejamento e Análise de Sistemas de Transportes" oferecida no segundo semestre de 2004.

\subsection{Aplicação do Modelo de Felder e Silverman}

Como pode ser visto na literatura, nem sempre são necessárias grandes transformações nos métodos de ensino para alcançar o equilíbrio desejado em sala de aula. Diante de diversas técnicas e recursos, basta a correta aplicação de cada um para conseguir um bom resultado.

Nesta seção, será tratado da aplicação do Modelo de Felder e Silverman como uma ferramenta de auxílio para a construção e elaboração adequada do CD distribuído aos alunos.

O primeiro passo para um CD bem desenvolvido é o de fazer com que o maior número de estudantes se interessem pelo seu conteúdo. Com isso, é necessário, antes de mais nada, reconhecer as diferentes preferências de 
aprendizagem dos estudantes. Para isso, utilizou-se do Index Learning Styles (ILS) que ainda está sendo desenvolvido por Felder e Soloman e que tem como base o modelo de Felder e Silverman.

Este instrumento, ou questionário, foi aplicado aos alunos e aos professores do terceiro ano que freqüentavam/lecionavam a disciplina citada, a fim de identificar quais seus estilos de aprendizagem. Obtiveram-se os seguintes resultados apresentados na Tabela 7.1 (Pereira et al., 2004).

Tabela 7.1 - Percentagens dos estilos de aprendizagem predominantes observados na turma de 2004 com seus professores

\begin{tabular}{ccc}
\hline $\begin{array}{c}\text { Estilos de } \\
\text { Aprendizagem }\end{array}$ & $\begin{array}{c}\text { Alunos do } 3^{\circ} \text { ano de } \\
\text { Engenharia Civil } \\
(n=59)\end{array}$ & $\begin{array}{c}\text { Professores da } \\
\text { turma de 2004 } \\
(n=3)\end{array}$ \\
\hline Ativo & $52 \%$ & $100 \%$ \\
Reflexivo & $48 \%$ & $0 \%$ \\
Sensorial & $92 \%$ & $100 \%$ \\
Intuitivo & $8 \%$ & $0 \%$ \\
Visual & $86 \%$ & $100 \%$ \\
Verbal & $14 \%$ & $0 \%$ \\
Seqüencial & $44 \%$ & $0 \%$ \\
Global & $56 \%$ & $100 \%$ \\
\hline
\end{tabular}

Os resultados observados nesses estudos revelaram percentuais mais elevados nos estilos ativo, sensorial, visual e global. Entretanto, esses estilos de aprendizagem nem sempre são alcançados pelos métodos "tradicionais" de ensino. É interessante notar que, embora os professores apresentem as mesmas preferências de aprendizagem de seus alunos, usualmente ensinam de maneira a não satisfazê-los, ou seja, adotam um estilo de ensino "tradicional", que privilegia os estudantes reflexivos, intuitivos, verbais e seqüenciais. Tal fato pode ser justificado pela tendência de ensinar da mesma maneira como aprenderam.

Neste sentido, com o propósito de atingir senão todos, pelo menos a maioria dos estilos de aprendizagem sugeridos por Felder e Soloman, o CD que foi desenvolvido utilizou-se de mídias como imagem, som, animação e vídeo, de forma a cobrir todos os nove módulos da disciplina em questão. 
Para avaliar se os estilos de aprendizagem identificados entre os estudantes do terceiro ano de Engenharia Civil foram alcançados com o material elaborado, procedeu-se à seleção de um dos nove módulos que compõem o CD.

Optou-se pelo módulo Análise de Sistemas de Transporte (Módulo 2), que se caracteriza por ser predominantemente informativo.

Para o Módulo 2 foram desenvolvidos onze "slides" ou "páginas" principais. As "páginas" foram então avaliadas uma a uma, segundo os estilos de aprendizagem, como demonstrado a seguir.
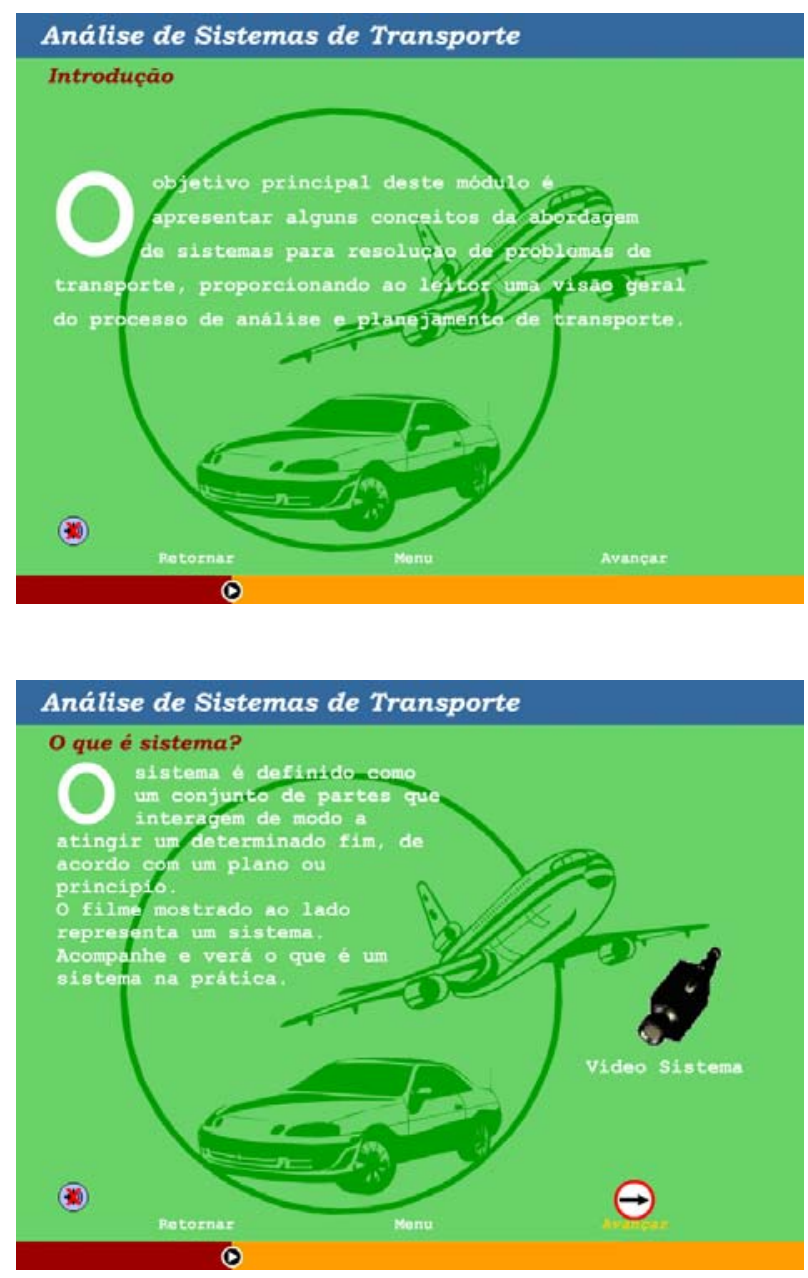

\section{Página 1}

Instrumento de Felder e Soloman A primeira página apresenta um texto escrito e falado, atingindo de imediato os estilos verbal, intuitivo e sensorial. $O$ aluno reflexivo foi estimulado a refletir sobre o tema. O sensorial foi atendido pelo uso de seus sentidos visuais e auditivos (texto e som). Como o texto leva o aluno a seguir para a próxima página, aqui, o estilo seqüencial é atingido.

\section{Página 2}

Instrumento de Felder e Soloman Nesta página, além do texto ser conceitual e apresentado de forma escrita e falada, atingindo respectivamente os intuitivos, verbais e sensoriais, é oferecida aos alunos oportunidade para reflexão, atendendo aos reflexivos. Apresenta um ícone que pode levar os alunos a um filme, que além de apresentar imagens e sons, oferece-lhes a oportunidade de contato com experiências reais, atendendo aos visuais e globais, respectivamente. Consegue também atender às necessidades do ativo (oportunidade de decidir se verá o filme ou não) e seqüencial (que pode permanecer no seu ritmo seqüencial). 

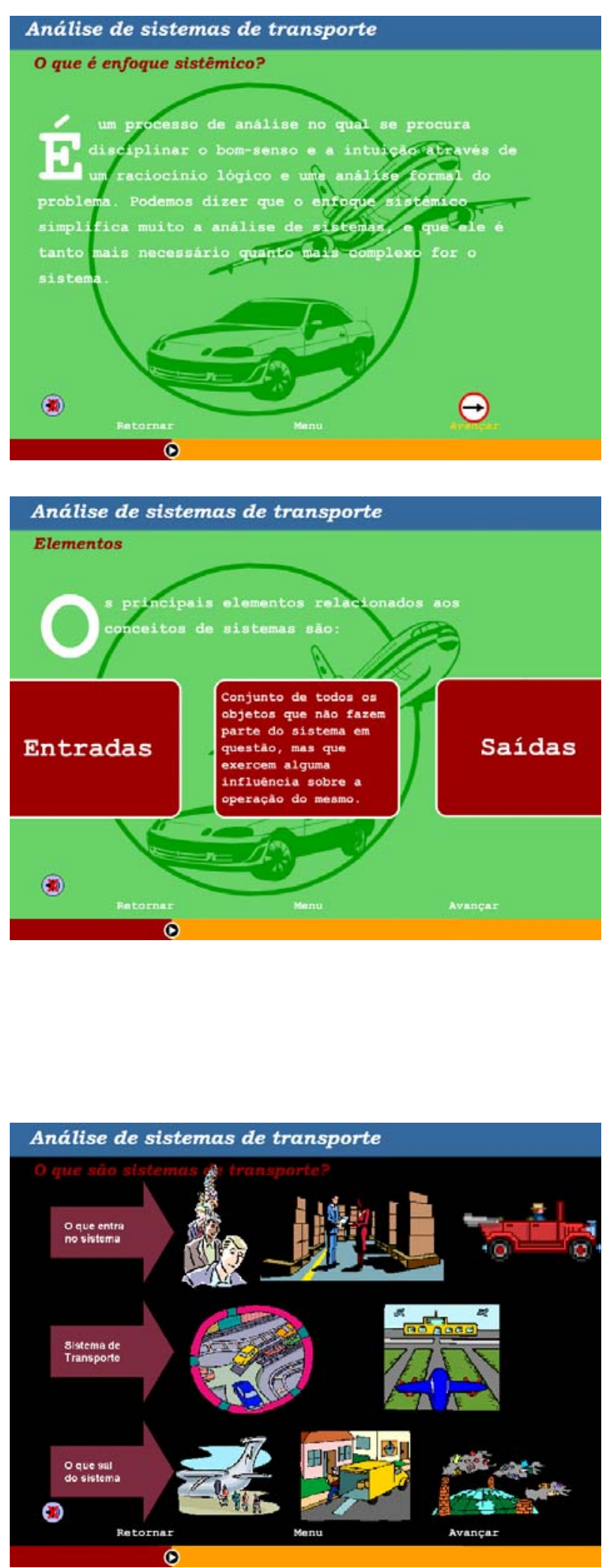

\section{Página 3}

Instrumento de Felder e Soloman

Aqui, conforme se pode observar, o texto escrito e falado atende aos estilos verbal e sensorial. O conceito em si atende às características do intuitivo. Como este texto leva a uma reflexão, atinge $o$ reflexivo, e a forma seqüencial como o texto induz o aluno atende aos seqüenciais.

\section{Página 4}

Instrumento de Felder e Soloman Nesta página, tanto os estilos ativo como reflexivo são atendidos, pois além de levar o aluno a uma reflexão sobre o assunto, permite a navegação pela página, em busca de outros conceitos sem seguir necessariamente, uma ordem. Atende então, tanto aos globais como aos seqüenciais. $\mathrm{O}$ texto conceitual escrito e falado atinge, mais uma vez, os estilos intuitivo, verbal e sensorial. A forma como os conceitos são apresentados, mesmo que em menor escala, atendem também ao estilo visual.

\section{Página 5}

Instrumento de Felder e Soloman Aqui, não se vê textos, mas imagens atendendo ao estilo visual em grande escala. $O$ texto apenas falado pode não atingir os verbais, mas atinge os sensoriais e, como leva o aluno a pensar sobre o assunto ouvido e mostrado, atende às necessidades dos reflexivos também. A seqüência mostrada não dá muita opção aos globais ou ativos, entretanto atinge os seqüenciais. 

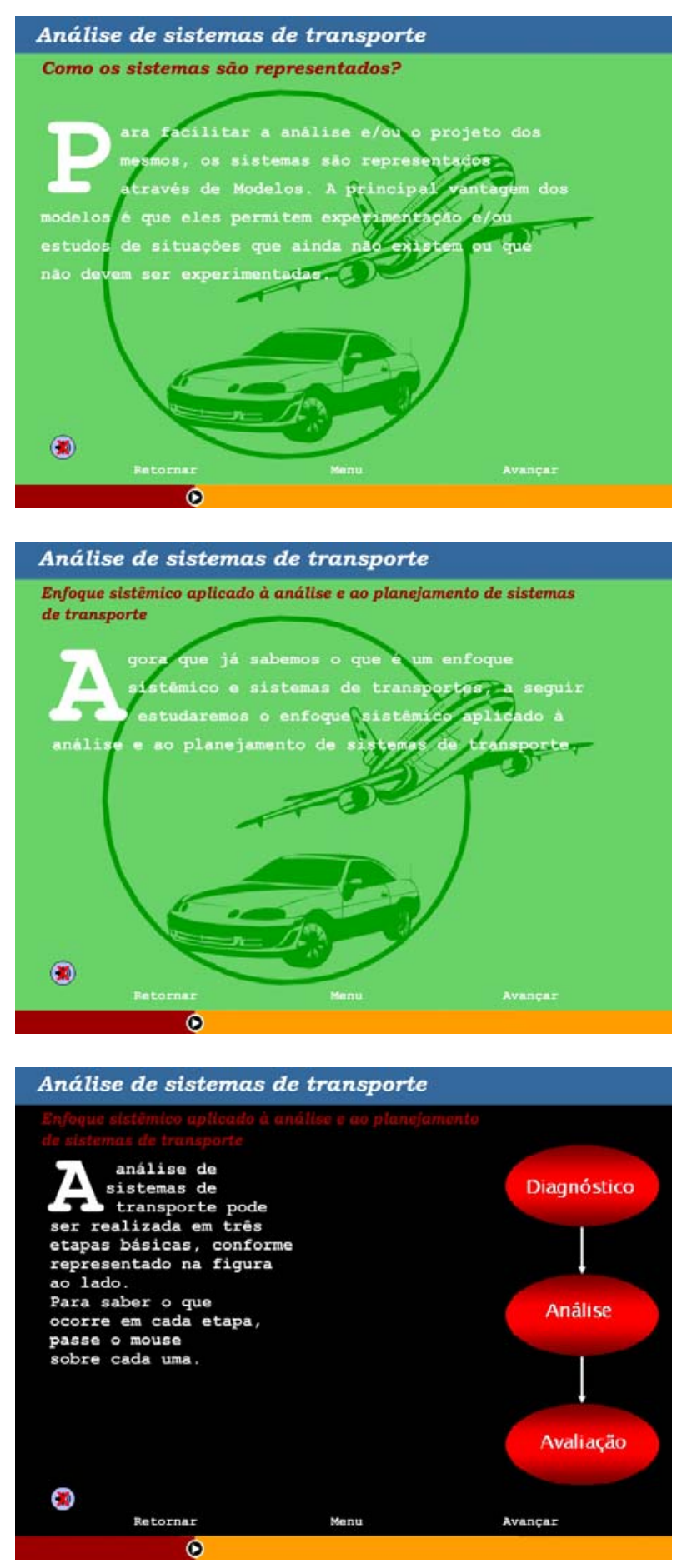

\section{Página 6}

Instrumento de Felder e Soloman Aqui, conforme se pode observar, o texto escrito e falado atende aos estilos verbal e sensorial. O conceito em si atende mais às características do intuitivo do que do sensorial. Como este texto leva a uma reflexão, atinge o reflexivo, e a forma seqüencial como o texto induz $O$ aluno atende aos seqüenciais.

\section{Página 7 \\ Instrumento de Felder e Soloman}

Com as mesmas características da "Página 3", aqui as dimensões atendidas são: reflexiva, sensorial, intuitiva, verbal e seqüencial.

\section{Página 8}

Instrumento de Felder e Soloman

Nesta página o pequeno texto apresentado de forma escrita, falada e conceitual atende às necessidades dos verbais, intuitivos e sensoriais. À direita da tela pode-se observar um fluxograma com som, atendendo, embora em escala menor, aos visuais. Além da oportunidade de reflexão (reflexivos) oferecida no texto, os alunos podem optar em ouvir ou não outros conceitos, seguindo ou não uma ordem, atingindo as características dos ativos, seqüenciais e globais. 


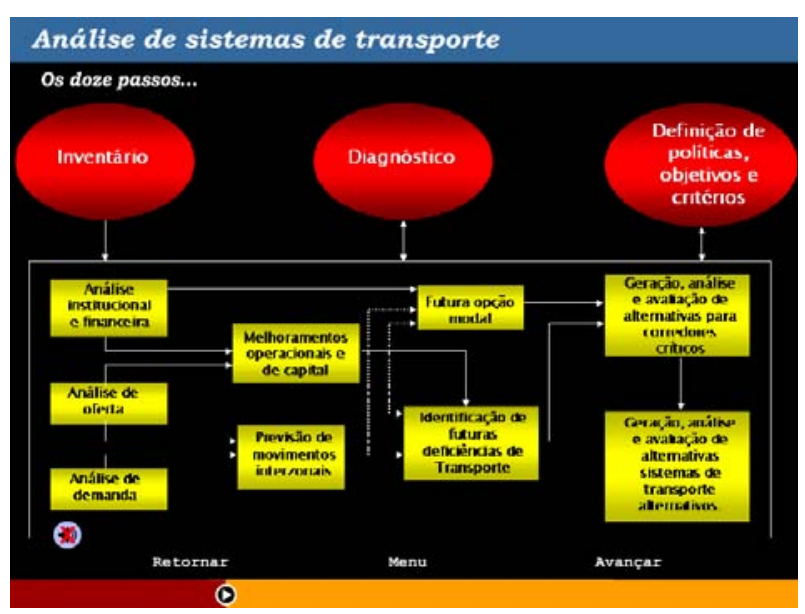

Página 9

Instrumento de Felder e Soloman

A característica da "Página 9" é inédita neste conjunto de páginas, pois apresenta apenas um fluxograma com seus conceitos apresentados através do som. Desta maneira, consegue atender aos visuais, mesmo que em menor escala do que os verbais. Induz o aluno a tomar atitudes para ouvir os conceitos que poderão ou não ser refletidos, atingindo os ativos em escala maior do que os reflexivos. A característica de interpretação e de conceitos atinge mais os intuitivos do que os sensoriais e a liberdade de escolha do fluxograma permite que o aluno siga o caminho que desejar, atendendo desta maneira, tanto aos seqüenciais como aos globais.

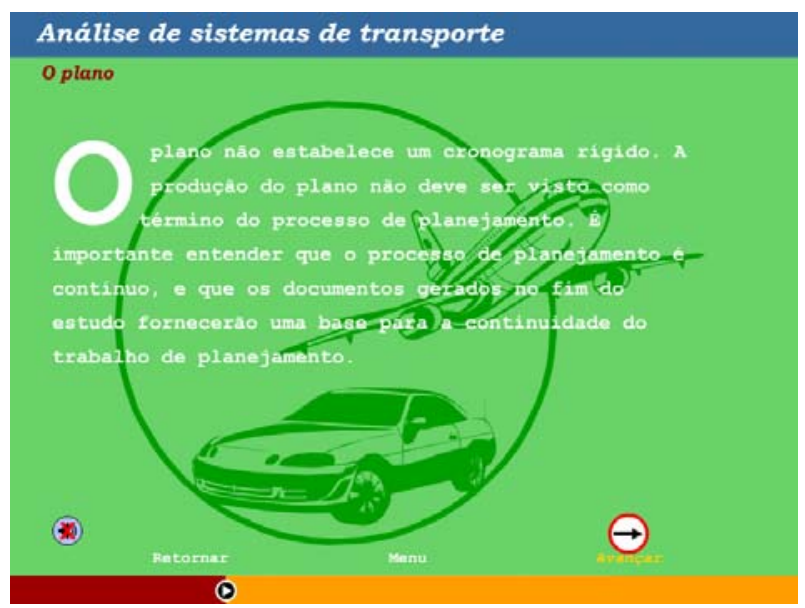

\section{Página 10}

\section{Instrumento de Felder e Soloman}

Embora aparentemente seja mais um texto escrito, apresenta um link que pode levar o aluno a arquivos com experiências reais sobre o tema em questão. Atende, desta maneira, tanto aos reflexivos como aos ativos, sensoriais como intuitivos, verbais como visuais e seqüenciais como globais.

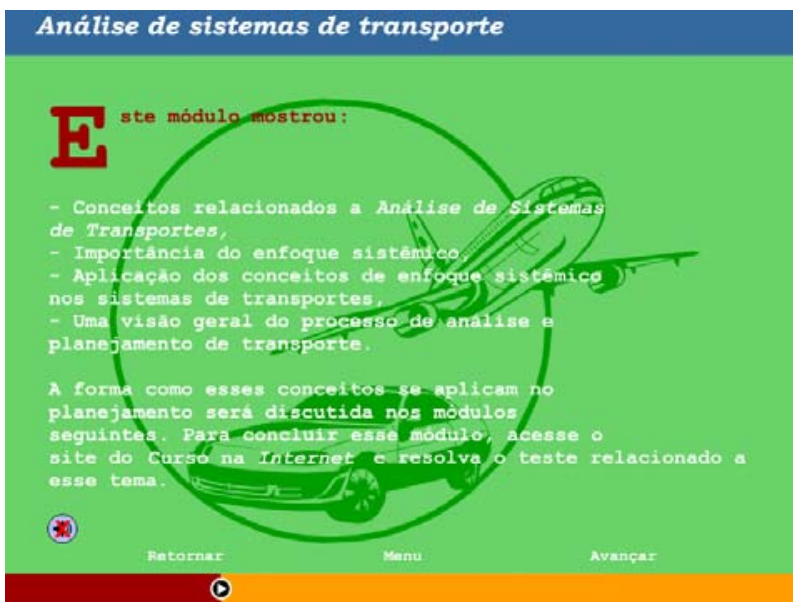

\section{Página 11}

Instrumento de Felder e Soloman

A última "página", além de apresentar um fechamento sobre o segundo módulo da disciplina, leva o aluno a uma reflexão sobre o que aprendeu. Apresenta também um link oferecendo a oportunidade do aluno acessar um site da Internet e resolver testes sobre o módulo. Atinge tanto os reflexivos como os ativos, os sensoriais como os intuitivos, os seqüenciais como os globais, e os verbais. Aqui, apenas o estilo visual não é atendido. 
Para fins de avaliação do material utilizado, a Figura 7.2 apresenta os resultados alcançados em cada uma das onze páginas, representados por barras associadas às dimensões dos estilos de aprendizagem, conforme caracterizado na Figura 7.1. O impacto que a inserção de recursos hipermídia pode ter causado no atendimento às necessidades educacionais dos alunos será comentado no capítulo de análise dos resultados.

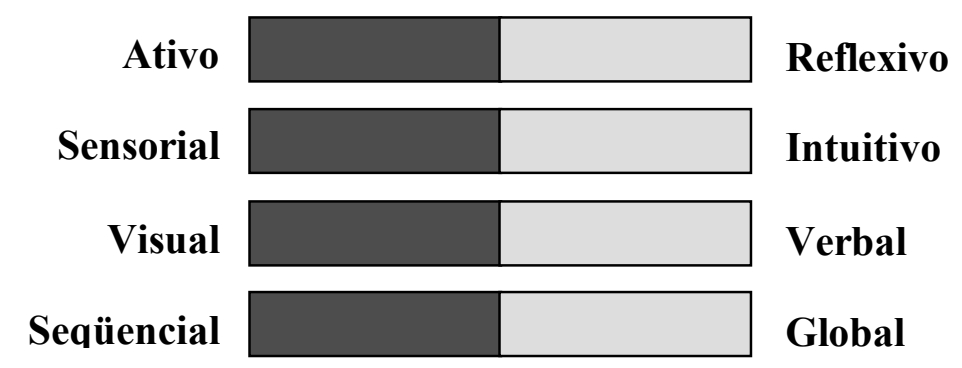

Figura 7.1: Dimensões dos estilos de aprendizagem

Página 1

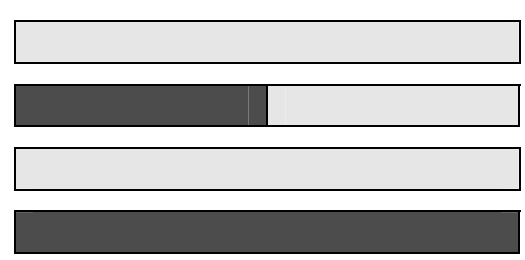

Página 4

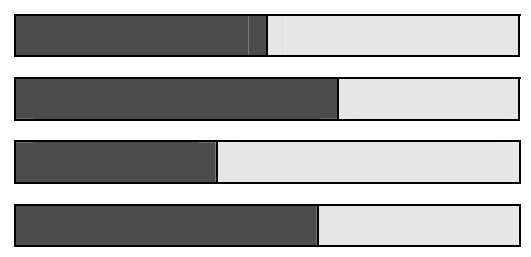

Página 7

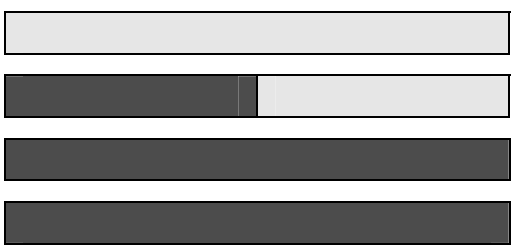

Página 2

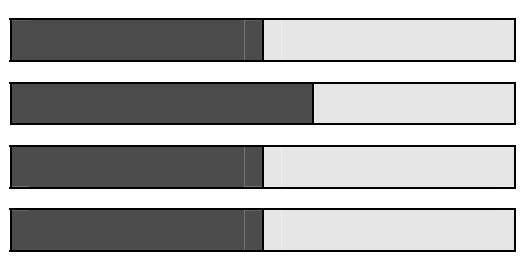

Página 5

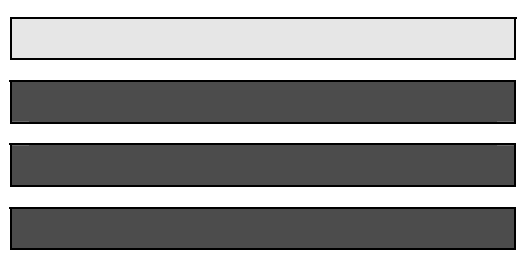

Página 8

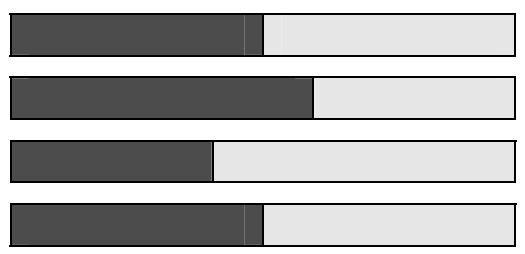

Página 3

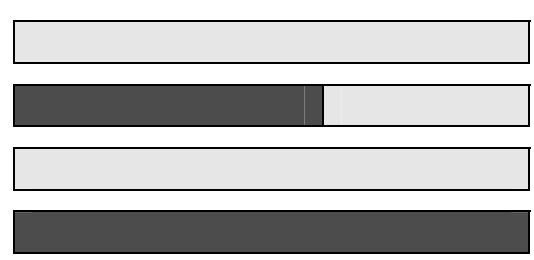

Página 6

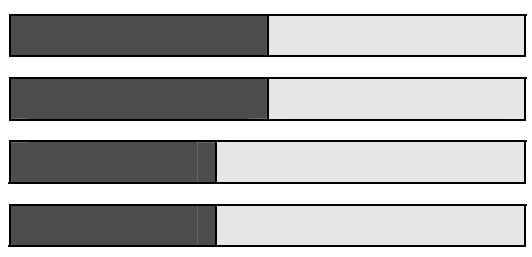

Página 9

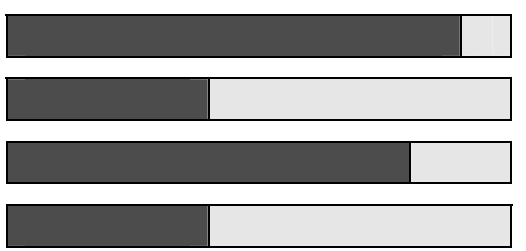



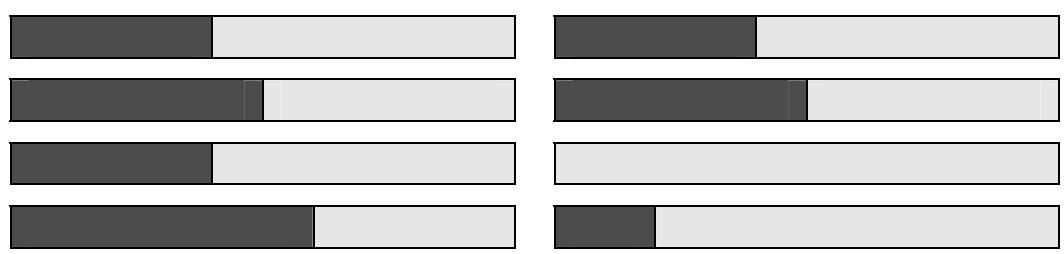

Figura 7.2 - Distribuição dos estilos de aprendizagem nas dimensões contempladas pelas "páginas" do módulo apresentado

Uma avaliação geral deste módulo é apresentada através da Tabela 7.2 e da Figura 7.3.

Tabela 7.2 - Avaliação das páginas do Módulo 2

\begin{tabular}{|c|c|c|c|c|c|c|c|c|c|c|c|}
\hline \multirow{2}{*}{ ESTILOS } & \multicolumn{11}{|c|}{ PÁGINAS } \\
\hline & 01 & 02 & 03 & 04 & 05 & 06 & 07 & 08 & 09 & 10 & 11 \\
\hline Ativo & & * & & $*$ & & & & $*$ & $*$ & & $*$ \\
\hline Reflexivo & $*$ & $*$ & $*$ & $*$ & $*$ & $*$ & * & * & * & $*$ & $\star$ \\
\hline Sensorial & * & * & * & * & * & * & * & * & * & * & * \\
\hline Intuitivo & $*$ & $*$ & $*$ & $*$ & & * & * & * & * & $*$ & $*$ \\
\hline Visual & $*$ & * & & * & * & & & * & * & & \\
\hline Verbal & $*$ & * & * & * & & * & * & * & * & $*$ & * \\
\hline Seqüencial & * & $*$ & * & $*$ & $*$ & $*$ & * & * & * & $*$ & $*$ \\
\hline Global & & $*$ & & * & & & & * & * & & * \\
\hline Ativo & & $\%$ & & & & & & $\operatorname{Re}$ & flexi & & \\
\hline Sensorial & & & $0 \%$ & & & & & Int & ruitiv & & \\
\hline Visual & & $50 \%$ & & & & & & Vet & rbal & & \\
\hline Global & & & & & & & & Se & qüenc & cial & \\
\hline
\end{tabular}

Figura 7.3: Avaliação geral do Módulo 02 
O exemplo do módulo apresentado mostrou que, com o acréscimo dessas mídias nos conteúdos oferecidos aos alunos, é possível atingir as quatro dimensões e os diferentes estilos de aprendizagem, satisfazendo todos os tipos de alunos. A idéia, no entanto, não é usar todas as técnicas ou mídias em todas as aulas, mas de maneira geral, ao decorrer do curso, atingir a todos os estilos de aprendizagem. Cabe lembrar que os demais módulos foram elaborados de maneira semelhante ao que foi aqui apresentado para o Módulo 2.

Uma avaliação parcial de todos os módulos do CD será apresentada no item “Análise dos Resultados”, bem como uma avaliação global do CD.

\subsection{Aplicação do Modelo de Kolb}

Nesta seção, será tratado da aplicação do Modelo de Kolb como mais uma ferramenta de auxílio para a construção e elaboração adequada do CD distribuído aos alunos. Neste modelo, o objetivo era o de estruturar todos os tópicos abordados na disciplina de modo que cada um deles pudesse contemplar os quatro estilos de aprendizagem que Kolb denominou de: divergente, assimilador, convergente e acomodador, conforme visto na literatura revisada neste trabalho. O objetivo é fazer com que ao final de cada módulo se complete o ciclo.

Para avaliar se os estilos de aprendizagem desenvolvidos por Kolb foram alcançados com o material elaborado, procedeu-se novamente à seleção dos dois dos nove módulos que compõem o CD. As "páginas" foram então avaliadas uma a uma, segundo os estilos de aprendizagem desse modelo, como demonstrado a seguir para o Módulo 02. 


\section{Módulo 02}
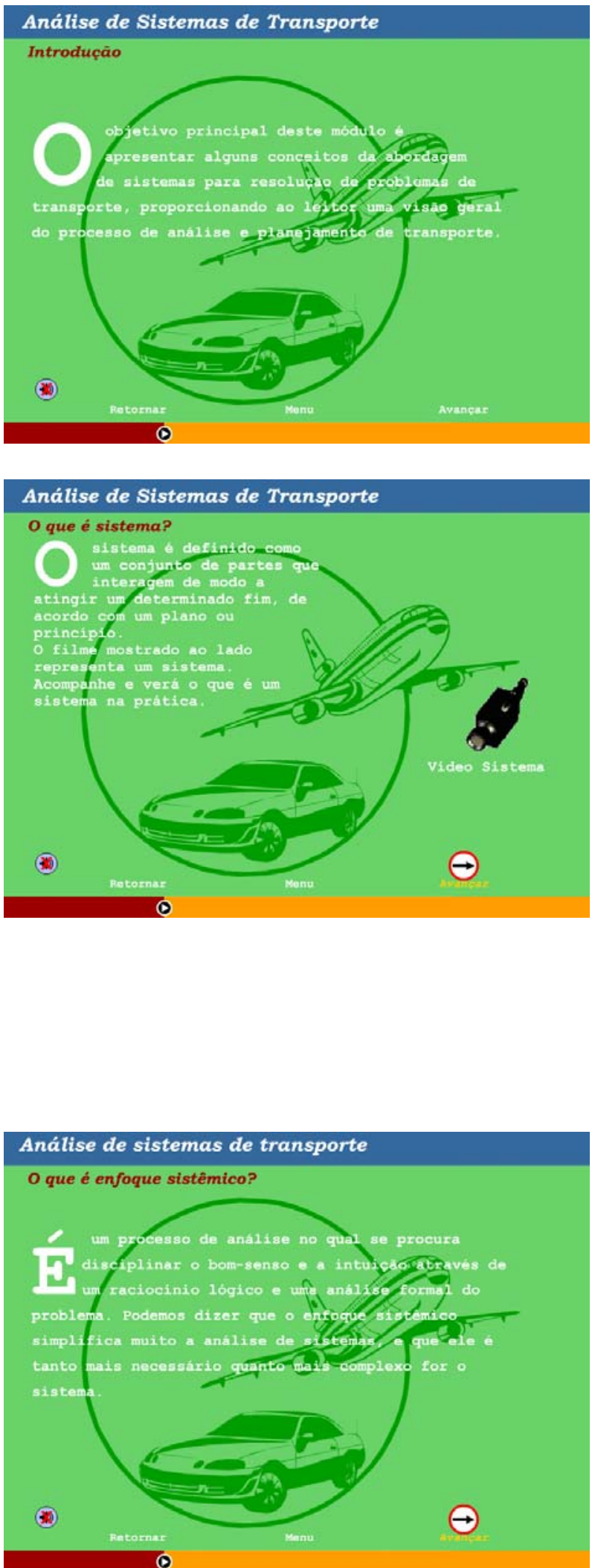

\section{Página 1}

\section{Modelo de Kolb}

O resumo apresentado na primeira página estimula o aluno a se envolver com a nova experiência, atingindo principalmente os divergentes, que preferem receber a informação através dos sentidos e a processá-la de maneira reflexiva (Fase 1 do Ciclo).

\section{Página 2}

Modelo de Kolb

Esta página inicia a apresentação de conceitos de forma escrita e falada, oferecendo aos alunos oportunidade para perceberem as novas informações tanto pela impressão que Ihes causa, quanto pela compreensão intelectual, e processá-las de modo reflexivo, contemplando os estilos divergente e assimilador. É ainda apresentado um ícone que pode levar os alunos a um filme, oferecendo-lhes a oportunidade de ter contato com a aplicação prática do conceito exposto, atingindo dessa forma os estudantes convergentes (Fases 1, 2 e 3 do Ciclo).

\section{Página 3}

\section{Modelo de Kolb}

Aqui, conforme se pode observar, trata-se de uma página conceitual e reflexiva, atingindo os estilos divergente e assimilador (Fases 1 e 2 do Ciclo). 

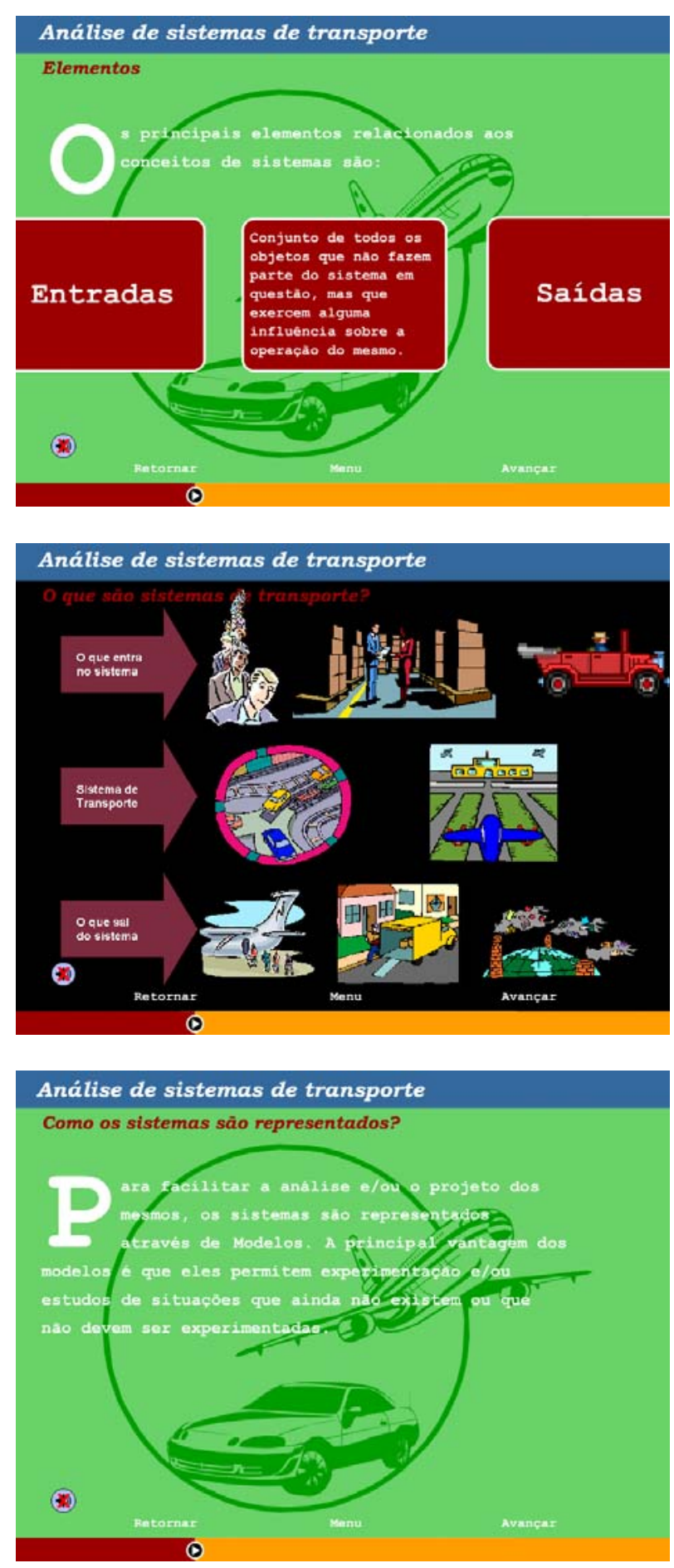

\section{Página 4}

Modelo de Kolb

Nesta página, três dos quatros estilos são atendidos, pois além de levar o aluno a refletir sobre 0 assunto (divergente e assimilador), permite a navegação em busca de outros conceitos, sem seguir necessariamente uma ordem (convergente) (Fases 1, 2 e 3 do Ciclo).

\section{Página 5}

Modelo de Kolb

Aqui, não se inclui texto escrito, apenas imagens. $O$ texto falado oferece aos alunos oportunidade de reflexão, atingindo os estilos divergente e assimilador (Fases 1 e 2 do Ciclo).

\section{Página 6 \\ Modelo de Kolb}

Esta página, apresentando $\mathrm{o}$ texto escrito de maneira conceitual, atende aos estilos divergente e assimilador pelas suas características de perceberem as informações (de modo sensorial e também pela compreensão intelectual) e as processarem de modo reflexivo (Fases 1 e 2 do Ciclo). 

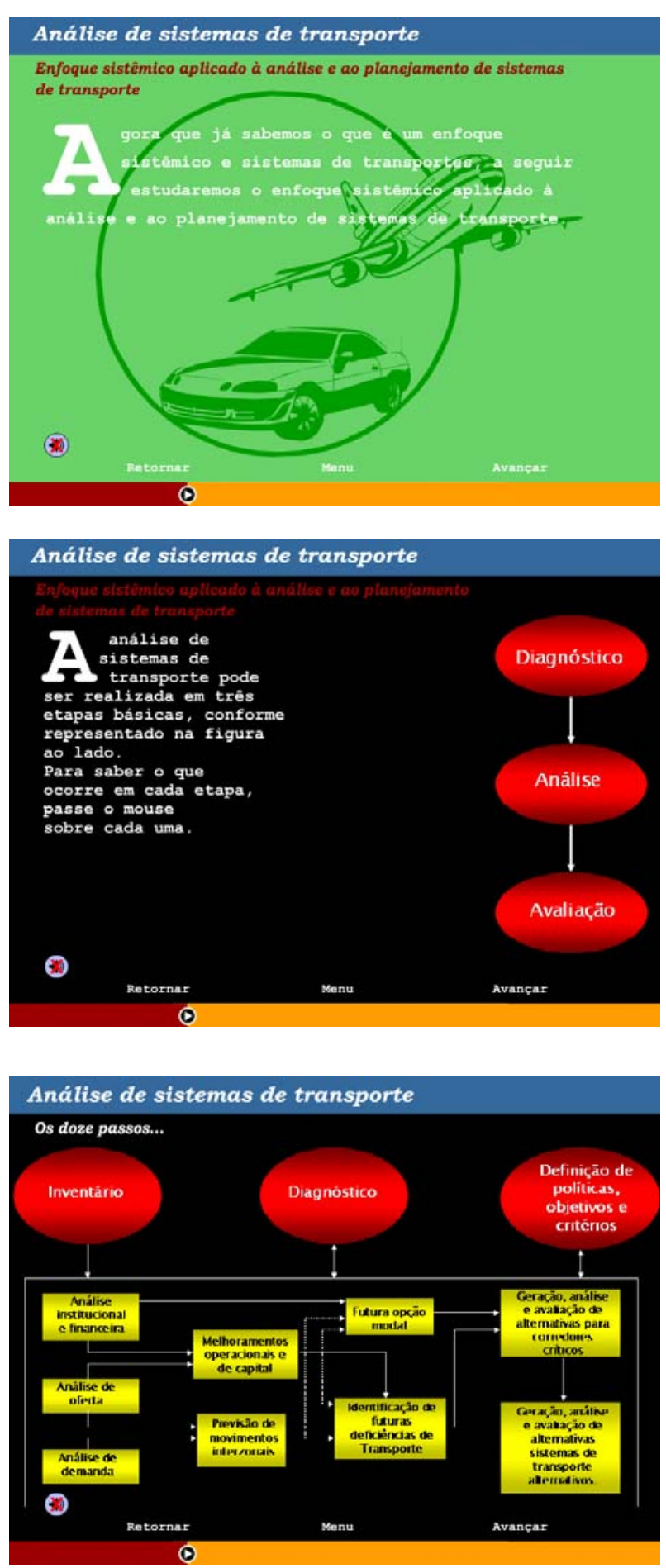

\section{Página 7}

Modelo de Kolb

Com as mesmas características da página anterior, os estilos divergente e assimilador são atendidos (Fases 1 e 2 do Ciclo).

\section{Página 8}

\section{Modelo de Kolb}

Nesta página, o pequeno texto apresentado de forma escrita, falada e conceitual, atende às necessidades dos divergentes e assimiladores. À direita da tela pode-se observar um fluxograma com som, que além da oportunidade de reflexão oferecida no texto (divergente e assimilador), permite aos alunos optar em ouvir ou não outros conceitos (convergente) (Fases 1, 2 e 3 do Ciclo).

\section{Página 9}

\section{Modelo de Kolb}

A característica desta página, de apresentar um fluxograma com seus conceitos apresentados através do som, induz o aluno a tomar atitudes para ouvir os conceitos (convergentes). A conceituação e interpretação atingem os estilos divergente e assimilador (Fases 1, 2 e 3 do Ciclo). 


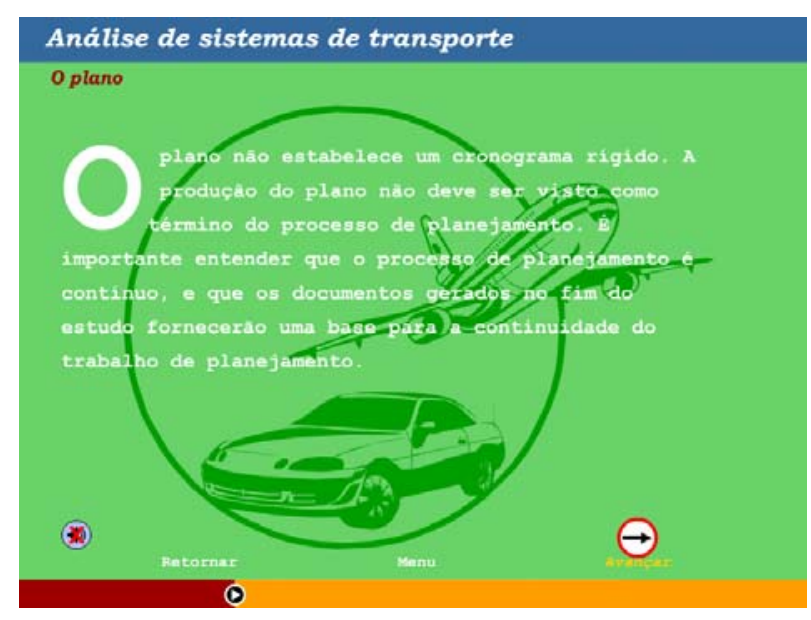

\section{Página 10 \\ Modelo de Kolb}

Esta página, apresentando o texto escrito de maneira conceitual, atende aos estilos divergente e assimilador, pelas suas características de processarem a informação de modo reflexivo (Fases 1 e 2 do Ciclo).

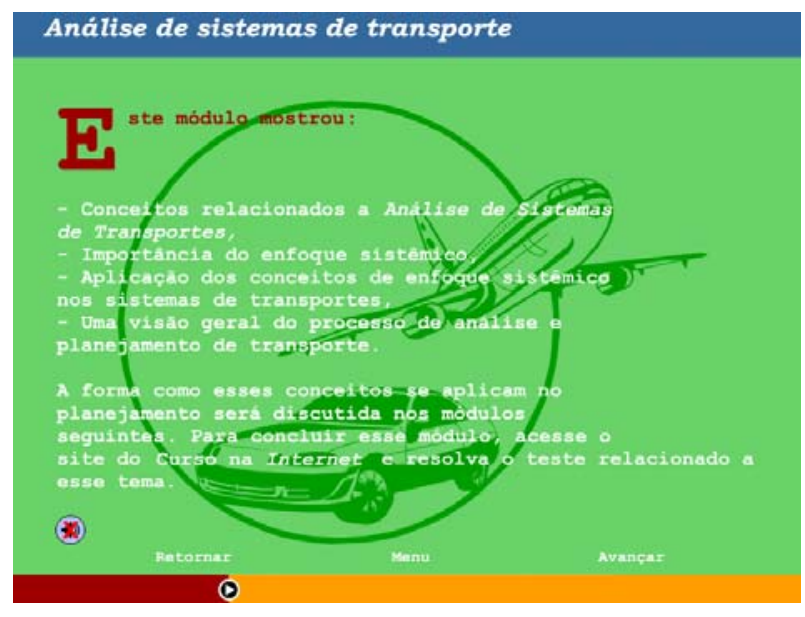

\section{Página 11 \\ Modelo de Kolb}

A última página apresenta um fechamento sobre o segundo módulo da disciplina, levando o aluno a refletir sobre o que aprendeu (divergentes e assimiladores). Além disso, apresenta também um link oferecendo a oportunidade do aluno acessar um site da Internet e resolver testes sobre o módulo (convergentes) e o envolvimento em novas experiências (acomodadores) (Fases 1, 2, 3 e 4 do Ciclo).

Como pôde ser observado nas páginas apresentadas do módulo 2, todas foram elaboradas e estruturadas tendo como base o Ciclo de Aprendizagem desenvolvido por Kolb, mostrando ser possível atingir os quatro estilos de aprendizagem, satisfazendo todos os tipos de alunos. O movimento através do ciclo pode ser, portanto, acompanhado pelo tipo de mídia e criatividade utilizada para a formulação de cada página.

\subsection{Aplicação do Modelo de Classificação: Taxonomia de Bloom}

Nesta seção, será discutida a aplicação do modelo de classificação denominado Taxonomia de Bloom. Como este modelo se apresenta como sendo relativamente preciso para a análise dos resultados educacionais na área cognitiva, abrangendo a memória, pensamento e solução de problemas, ele foi utilizado na etapa da técnica do seminário, onde justamente os alunos foram submetidos à busca de novos conhecimentos. 
Nesta etapa a turma foi dividida em oito grupos, e cada grupo apresentou conceitos e aplicações de uma técnica especificamente na área de Transportes. Os grupos ficaram divididos conforme mostra a Tabela 7.3.

Tabela 7.3: Os oito grupos associados às suas técnicas

\begin{tabular}{cc}
\hline Grupo & Técnica \\
\hline A & Redes Neurais Artificiais \\
B & Lógica Fuzzy \\
C & Algoritmos Genéticos \\
D & Sistemas de Informação Geográfica \\
E & Avaliação Multicritério \\
F & Autômatos Celulares \\
G & Simulated Annealing \\
H & Estatística Espacial \\
\hline
\end{tabular}

À medida que os grupos se apresentavam, o professor da disciplina respondia às seis questões mostradas na Tabela 7.4 , que representam as seis categorias ou níveis da Taxonomia de Bloom.

Tabela 7.4: Avaliação através da Taxonomia de Bloom utilizada pelo professor

1) O grupo simplesmente REPRODUZIU o que foi apresentado, demonstrando que memorizou as informações sobre a técnica apresentada

( ) Totalmente ( ) Parcialmente ( ) Quase nada ( ) Nada

2) O grupo apenas repetiu o que aprendeu, mas COMPREENDEU de tal maneira para afirmá-lo de outra forma

( ) Totalmente ( ) Parcialmente ( ) Quase nada ( ) Nada

3) O grupo APLICOU aquilo que aprendeu na resolução de problemas diferentes do que já tinha visto

( ) Totalmente ( ) Parcialmente ( ) Quase nada ( ) Nada

4) O grupo identificou a estrutura de um todo e EXPLICOU AS INTER-RELAÇÕES existentes

( ) Totalmente ( ) Parcialmente ( ) Quase nada ( ) Nada

5) O grupo EXPRESSOU SUAS PRÓPRIAS IDÉIAS e/ou experiências a fim de formar em produto único

( ) Totalmente ( ) Parcialmente ( ) Quase nada ( ) Nada

6) O grupo foi capaz de comPARAR dois produtos e justificar, expressando suas idéias

( ) Totalmente ( ) Parcialmente ( ) Quase nada ( ) Nada

Com isso, pretendeu-se que o professor avaliasse o que o aluno absorveu da técnica pela qual o seu grupo ficou responsável, classificando seu comportamento como resultado da participação do aluno no seminário. Sabese que é uma forma indireta e subjetiva de avaliação para um grupo, uma vez que as pessoas que apresentam tornam-se responsáveis por todo o seu grupo. 
Mesmo assim, é considerada uma avaliação significativa, uma vez que esta é hoje uma das características essenciais para o perfil do profissional no mercado de trabalho competitivo e globalizado: senso de responsabilidade. A análise dessa avaliação será também vista no próximo capítulo. 


\section{ANÁLISE DOS RESULTADOS}

Considerando que a proposta desta pesquisa era avaliar e explorar alternativas pedagógicas para adequação do processo de ensino-aprendizagem ao contexto de rápidas e constantes inovações hoje observado, neste item serão tratados dos resultados obtidos com as aplicações dos métodos e alternativas selecionadas.

Primeiramente será feita uma avaliação e análise do uso do software WebCT pelos alunos. Em seguida será apresentada uma análise dos módulos do CD, uma análise global segundo o modelo de Felder e Silverman e o modelo de Kolb e uma análise do modelo da Taxonomia de Bloom. Finalmente será apresentada uma análise das avaliações qualitativas e quantitativas.

\subsection{Avaliação e Análise do Software WebCT}

Através de recursos disponíveis no próprio software WebCT, tem-se a possibilidade de avaliar e analisar a participação do aluno no site do curso. Na Figura 8.1 observa-se, nas colunas da tabela, a data do primeiro e do último dia de acesso ao site e também como foi a navegação do aluno no site, contado pelo número de visitas às páginas do curso. 


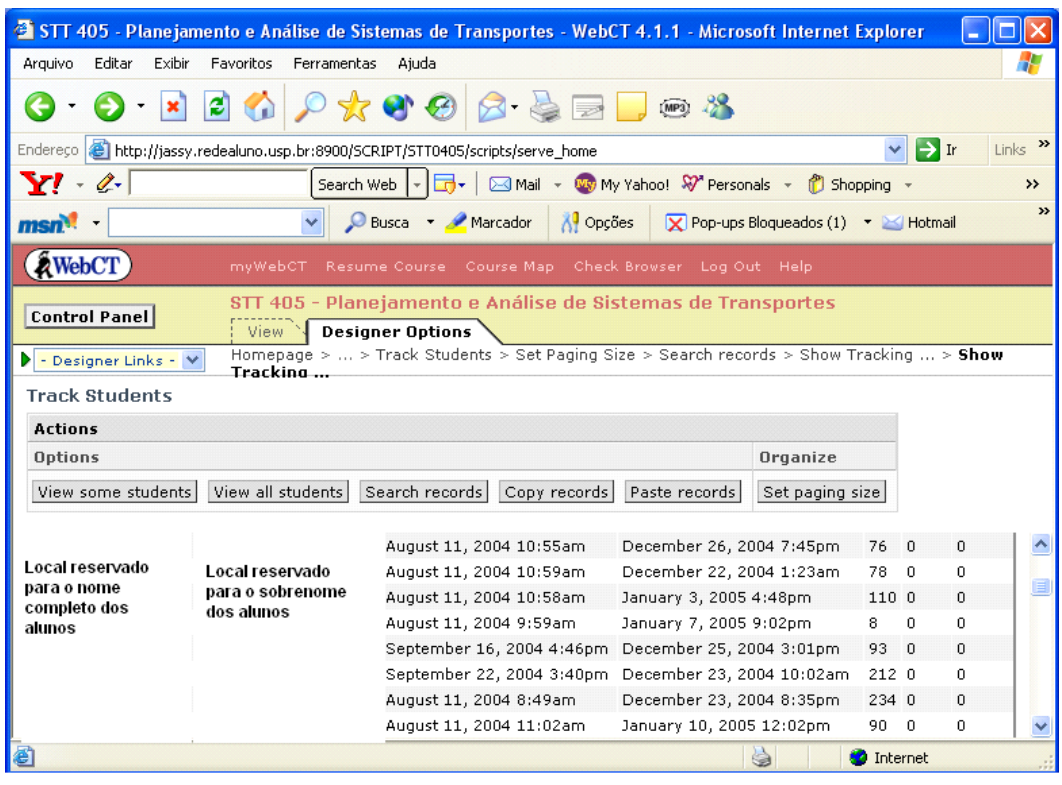

Figura 8.1: Visualização do relatório de acompanhamento dos alunos no WebCT: primeiro acesso, último acesso e número de hits.

A Tabela 8.1 foi construída com base nos dados fornecidos pelo WebCT. Podese observar que $80,49 \%$ dos alunos iniciaram o acesso ao site educativo no mês de agosto (mês que se deu início o curso) e o último acesso foi em dezembro (mês em que o curso se encerrou). Isso mostra que houve um interesse significativo dos alunos em utilizar o site durante todo o curso.

Da mesma maneira, a terceira coluna ("Hits"), mostra que uma quantidade alta de alunos (também cerca de $80 \%$ ) apresentou um número elevado (acima de 50) de visitas às páginas do site, confirmando o interesse pelo uso da ferramenta. O WebCT também pode fornecer quantas e quais páginas foram acessadas individualmente por aluno, tais como: Notas, Conteúdo, Transparências, etc. Um exemplo disso pode ser visto na Figura 8.2. 
Tabela 8.1: Primeiro e último acesso dos alunos no WebCT e o número de visitas às páginas

\begin{tabular}{|c|c|c|c|}
\hline Full Name & First Access & Last Access & Hits \\
\hline A & August 11, 2004 9:59am & December 1, 2004 2:40pm & 7 \\
\hline $\mathrm{B}$ & August 11, 2004 2:52pm & December 22, 2004 10:09am & 11 \\
\hline C & October 19, 2004 4:15pm & December 21, 2004 2:31pm & 11 \\
\hline $\mathrm{D}$ & August 11, 2004 11:04am & December 21, 2004 6:17pm & 15 \\
\hline $\mathrm{E}$ & August 11, 2004 3:51pm & December 21, 2004 8:40pm & 34 \\
\hline $\mathrm{F}$ & August 11, 2004 2:46pm & December 21, 2004 3:06pm & 43 \\
\hline G & September 21, 2004 4:22pm & December 21, 2004 11:13pm & 46 \\
\hline $\mathrm{H}$ & September 1, 2004 2:28pm & December 21, 2004 5:04pm & 47 \\
\hline 1 & August 11, 2004 8:53am & December 22, 2004 9:55am & 51 \\
\hline $\mathrm{J}$ & October 19, 2004 4:31pm & December 22, 2004 10:33am & 58 \\
\hline $\mathrm{L}$ & August 11, 2004 4:08pm & December 21, 2004 4:02pm & 66 \\
\hline $\mathrm{M}$ & August 11, 2004 10:53am & December 22, 2004 10:13am & 71 \\
\hline $\mathrm{N}$ & August 11, 2004 10:55am & December 16, 2004 3:24pm & 72 \\
\hline 0 & August 11, 2004 11:01am & December 21, 2004 10:37pm & 73 \\
\hline $\mathrm{P}$ & August 11, 2004 3:09pm & December 21, 2004 5:02pm & 73 \\
\hline Q & August 11, 2004 2:58pm & December 21, 2004 10:34pm & 75 \\
\hline $\mathrm{R}$ & August 11, 2004 10:59am & December 22, 2004 1:23am & 78 \\
\hline$S$ & August 11, 2004 2:56pm & December 21, 2004 3:43pm & 80 \\
\hline $\mathrm{T}$ & August 11, 2004 11:02am & December 21, 2004 4:07pm & 83 \\
\hline$U$ & August 11, 2004 4:04pm & December 21, 2004 11:15pm & 84 \\
\hline $\mathrm{V}$ & August 11, 2004 9:09am & December 21, 2004 12:34pm & 88 \\
\hline$x$ & August 11, 2004 11:09am & December 21, 2004 3:09pm & 88 \\
\hline Z & August 11, 2004 3:00pm & December 21, 2004 10:58pm & 89 \\
\hline AA & September 16, 2004 4:46pm & December 21, 2004 3:07pm & 91 \\
\hline BB & August 11, 2004 2:53pm & December 21, 2004 2:49pm & 91 \\
\hline $\mathrm{CC}$ & August 11, 2004 11:11am & December 22, 2004 12:43am & 93 \\
\hline DD & August 11, 2004 2:55pm & December 22, 2004 10:03am & 94 \\
\hline EE & September 1, 2004 2:54pm & December 21, 2004 9:57pm & 98 \\
\hline $\mathrm{FF}$ & September 1, 2004 9:12am & December 21, 2004 2:36pm & 101 \\
\hline GG & September 1, 2004 9:14am & December 21, 2004 9:48pm & 101 \\
\hline $\mathrm{HH}$ & August 11, 2004 10:58am & December 22, 2004 10:04am & 108 \\
\hline II & August 11, 2004 10:57am & December 22, 2004 9:59am & 126 \\
\hline $\mathrm{JJ}$ & August 11, 2004 4:02pm & December 22, 2004 9:39am & 169 \\
\hline LL & August 11, 2004 3:05pm & December 22, 2004 10:25am & 171 \\
\hline MM & August 11, 2004 2:48pm & December 22, 2004 12:27am & 175 \\
\hline NN & August 11, 2004 5:00pm & December 21, 2004 6:42pm & 182 \\
\hline $\mathrm{OO}$ & August 11, 2004 8:51am & December 21, 2004 2:42pm & 183 \\
\hline PP & September 22, 2004 3:40pm & December 21, 2004 4:01pm & 208 \\
\hline$Q Q$ & August 11, 2004 8:49am & December 21, 2004 2:44pm & 229 \\
\hline $\mathrm{RR}$ & August 11, 2004 9:11am & December 22, 2004 12:46am & 331 \\
\hline SS & August 11, 2004 9:23am & December 22, 2004 9:19am & 367 \\
\hline
\end{tabular}




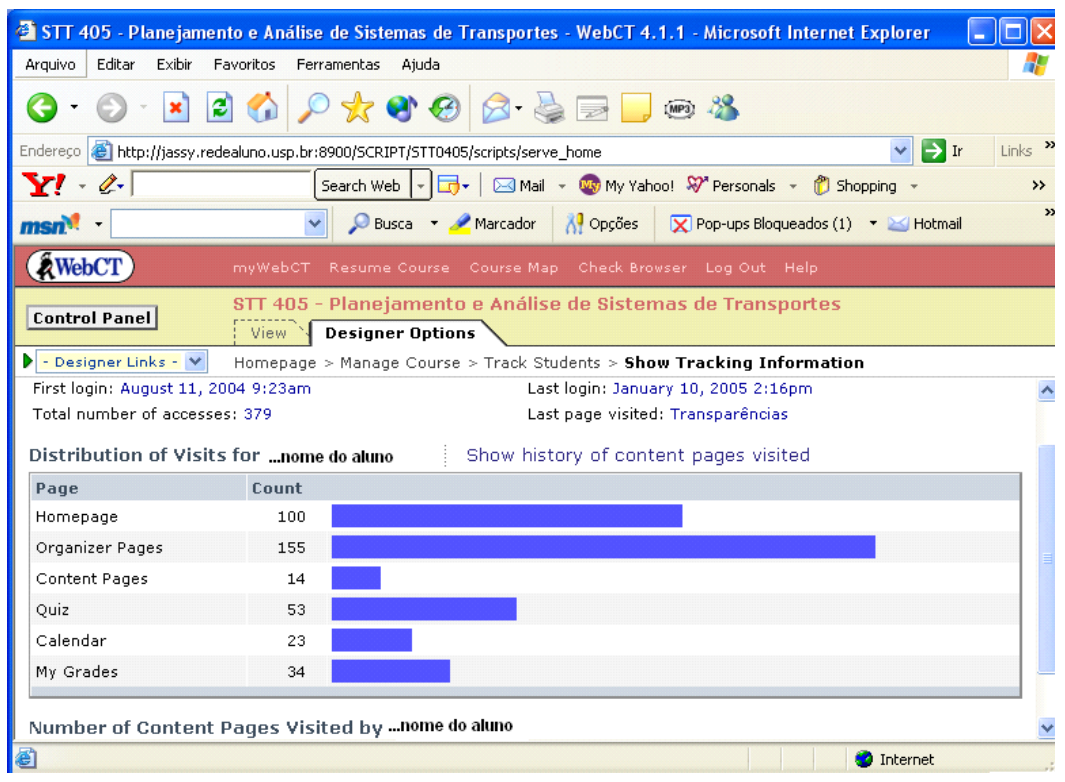

Figura 8.2: Histórico das páginas visitadas por um aluno (cujo nome foi omitido intencionalmente)

No exemplo apresentado na Figura 8.2 pode-se observar que um aluno acessou, por exemplo, 34 vezes a página das notas, 23 vezes a página de calendário, etc. E que, por exemplo, a última página que visitou foi a de transparências.

O WebCT apresenta, além do que foi mostrado, testes (quiz). No caso desta pesquisa foi elaborada uma lista de perguntas que poderiam ou não ser respondidas pelos alunos ao final de cada módulo. Dos 40 alunos matriculados na disciplina, a média de retorno das questões respondidas de todos os nove módulos foi de $75 \%$.

Em síntese, pode-se dizer que a participação dos alunos durante o curso se mostrou bastante satisfatória no que diz respeito à utilização do software WebCT como meio de ajudar e modificar, mesmo que de maneira tênue, o processo de ensino-aprendizagem, tornando assim a aprendizagem mais atrativa aos alunos. 


\subsection{Análise dos Módulos do CD segundo o Modelo de Felder e Silverman}

Como já foi citado na literatura, Modelos de Estilos de Aprendizagem procuram explicar como as pessoas aprendem. Já Instrumentos como o ILS, utilizado nessa pesquisa, servem para estimar as maneiras pelas quais os estudantes preferem perceber e processar as novas informações e experiências.

Com o trabalho, pode-se reafirmar o que foi dito na literatura, ou seja, que a maior parte dos estudantes de engenharia dá ênfase aos estilos visual, sensorial, ativo e global. Isto, conforme já visto, conflita com as estratégias de ensino predominantes na engenharia, que, de maneira geral, são: verbal, intuitivo, reflexivo e seqüencial. Este desequilíbrio prejudica o desempenho dos alunos, o que pode inclusive causar para a sociedade a perda de engenheiros potencialmente bons.

Com o propósito de atingir parte do objetivo do trabalho, ou seja, atender a maioria das dimensões dos estilos de aprendizagem em sala de aula, foi necessário complementar a metodologia tradicional com a utilização de documentos hipermídia, fazendo-se uso de mídias como imagem, som, vídeo e animação.

Com o resultado dos percentuais de estilos de aprendizagem observados na turma de 2004 do curso de Engenharia Civil (Tabela 8.2 e Figura 8.3), após a aplicação do ILS (Index Learning Styles) nesta turma, O CD que foi produto deste trabalho de tese, foi cuidadosamente elaborado de forma que todos os oito estilos de aprendizagem fossem alcançados. Na Tabela 8.2 é apresentada uma análise geral feita com os conceitos do Modelo de Felder e Silverman e do Índice de Felder e Soloman. 
Tabela 8.2: Análise geral dos módulos do $C D$ de acordo com o Modelo de Felder e Silverman

\begin{tabular}{|c|c|c|c|c|c|c|c|c|c|}
\hline \multirow{2}{*}{ Módulo } & \multirow{2}{*}{$\begin{array}{c}\text { Número } \\
\text { de } \\
\text { Páginas }\end{array}$} & \multicolumn{2}{|c|}{ Processamento } & \multicolumn{2}{|c|}{ Percepção } & \multicolumn{2}{|c|}{ Input } & \multicolumn{2}{|c|}{ Entendimento } \\
\hline & & Ativo & Reflexivo & Sensorial & Intuitivo & Visual & Verbal & Global & Sequencial \\
\hline 1 & 38 & $65 \%$ & $35 \%$ & $60 \%$ & $40 \%$ & $60 \%$ & $40 \%$ & $65 \%$ & $35 \%$ \\
\hline 2 & 11 & $40 \%$ & $60 \%$ & $60 \%$ & $40 \%$ & $50 \%$ & $50 \%$ & $40 \%$ & $60 \%$ \\
\hline 3 & 50 & $40 \%$ & $60 \%$ & $35 \%$ & $65 \%$ & $50 \%$ & $50 \%$ & $50 \%$ & $50 \%$ \\
\hline 4 & 38 & $40 \%$ & $60 \%$ & $40 \%$ & $60 \%$ & $55 \%$ & $45 \%$ & $55 \%$ & $45 \%$ \\
\hline 5 & 34 & $30 \%$ & $70 \%$ & $60 \%$ & $40 \%$ & $60 \%$ & $40 \%$ & $30 \%$ & $70 \%$ \\
\hline 6 & 49 & $10 \%$ & $90 \%$ & $60 \%$ & $40 \%$ & $65 \%$ & $35 \%$ & $25 \%$ & $75 \%$ \\
\hline 7 & 46 & $15 \%$ & $85 \%$ & $40 \%$ & $60 \%$ & $50 \%$ & $50 \%$ & $25 \%$ & $75 \%$ \\
\hline 8 & 39 & $25 \%$ & $75 \%$ & $45 \%$ & $55 \%$ & $55 \%$ & $45 \%$ & $30 \%$ & $70 \%$ \\
\hline 9 & 60 & $40 \%$ & $60 \%$ & $40 \%$ & $60 \%$ & $55 \%$ & $45 \%$ & $45 \%$ & $55 \%$ \\
\hline
\end{tabular}

Para torná-los mais claros (e visuais), os resultados apresentados na Tabela 8.2 são representados graficamente na Figuras 8.3. As linhas horizontais representam o perfil global da turma, caracterizado com o uso do ILS.

\section{Ativo/Sensorial/Visual/Global}

Reflexivo/Intuitivo/Verbal/Seqüencial

Turma de 2004

Ativo/Reflexivo

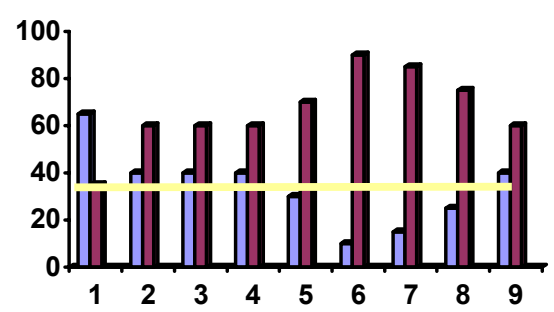

Visual/Verbal

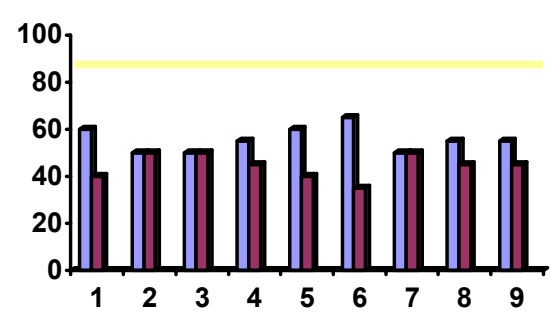

Sensorial/Intuitivo

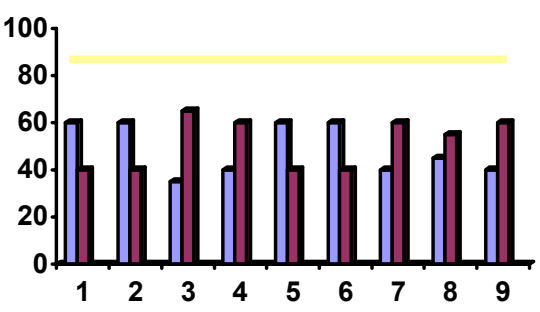

Global/Seqüencial

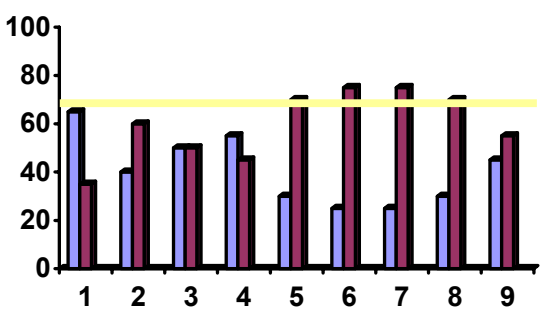

Figura 8.3: Gráficos com a análise geral dos nove módulos do CD segundo o Modelo de Felder e Silverman

Como pode ser observado através da Figura 8.3, durante a elaboração do CD, 
em todos os nove módulos tentou-se atender a todos os estilos de aprendizagem de maneira adequada. Nota-se, entretanto, que os módulos 6 e 7, respectivamente "Equilíbrio entre demanda e oferta" e "Tarifação de Transportes", possuem um caráter informativo, ou seja, boa parte do conteúdo desses módulos são teorias e conceitos. Essa característica dificulta um pouco o objetivo de atingir estilos de alunos que possuem uma preferência de aprendizagem ativa e global, o que justifica seu baixo índice nesses módulos (10\% e $15 \%$, e $25 \%$ e $25 \%$, respectivamente). Por outro lado, o módulo 1 , "Transporte e Sociedade", ultrapassa o percentual da turma para os estilos ativo e global.

Os outros módulos tiveram um desempenho regular diante das características apresentadas pela turma. Pode-se dizer, entretanto, que através da relação entre os resultados obtidos com a utilização do ILS para estimar as preferências de aprendizagem da turma e o resultado obtido com a avaliação feita com o CD através do Modelo de Felder e Silverman, ainda que de maneira parcial, todos os tipos de estudantes foram alcançados, contribuindo para um ensino mais dinâmico e atrativo.

Da mesma forma, a Figura 8.4 mostra uma avaliação global feita com todos os módulos do CD. A figura mostra que, com o uso de diferentes mídias nos conteúdos oferecidos aos alunos, é possível atingir as quatro dimensões e os diferentes estilos de aprendizagem de todos os tipos de estudantes.

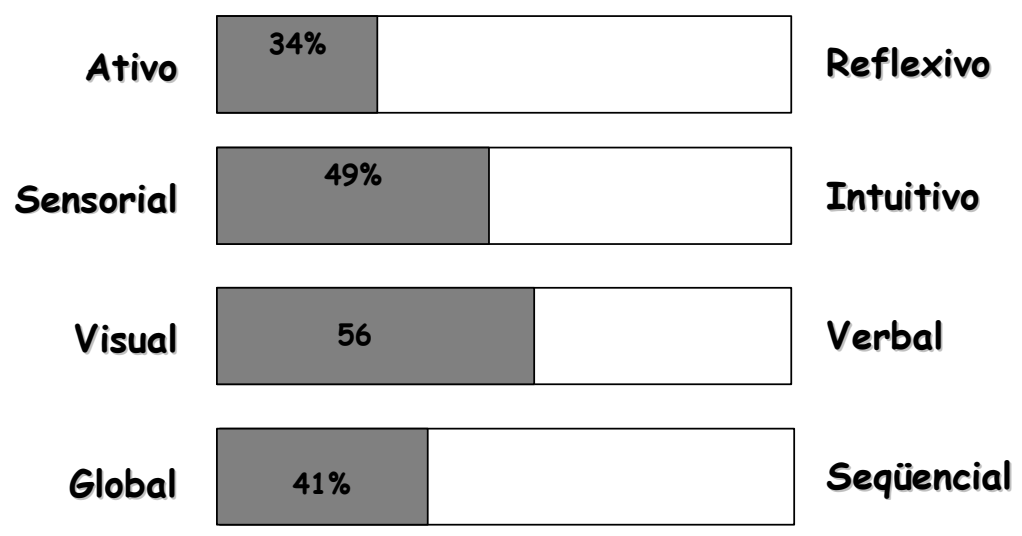

Figura 8.4: Avaliação global do CD 
Desta forma, complementando o método de ensino tradicional com técnicas diversas, espera-se conseguir um estilo de ensino efetivo para todos os estudantes, melhorando o processo de ensino-aprendizagem.

\subsection{Análise dos Módulos do CD segundo o Modelo de Kolb}

Segundo a literatura pesquisada, o modelo ou ciclo de Kolb é aquele onde a aprendizagem é entendida como um processo que envolve duas dimensões: a percepção da informação e o processamento desta. A interseção desses eixos dá origem aos quatro estilos de aprendizagem: divergente, assimilador, convergente e acomodador.

Diante disto, o CD desenvolvido nesta pesquisa utilizou esta ferramenta com o objetivo de estruturar todos os módulos ali contidos, de modo que cada um deles pudesse contemplar também os quatro estilos de aprendizagem desenvolvidos por Kolb, fazendo com que o ciclo se completasse ao final de cada módulo.

Isto pode ser observado através das figuras mostradas a seguir, onde se verifica que as diversas páginas de cada módulo foram elaboradas e estruturadas tendo como base o Ciclo de Aprendizagem desenvolvido por Kolb. O movimento através do ciclo pode ser, portanto, acompanhado pelo tipo de mídia e criatividade utilizada para a formulação de cada página.

\section{- Módulo 1}

O primeiro módulo do $C D$ apresentou 38 páginas ou slides, como pode ser visto na Figura 8.5. A fase 1 do ciclo de Kolb é representada pelo estilo divergente e foi atingida por todas as páginas (100\%). A fase 2 (Assimilador) foi atingida por $97 \%$ das páginas. A fase 3 do ciclo, representada pelo estilo convergente foi atingida por $68 \%$ das páginas elaboradas no Módulo 1. Finalmente, a quarta fase (Acomodador) foi atingida por 2,6\% das páginas ou slides, completando, desta maneira, todo o ciclo, quando este pode então ser recomeçado. 

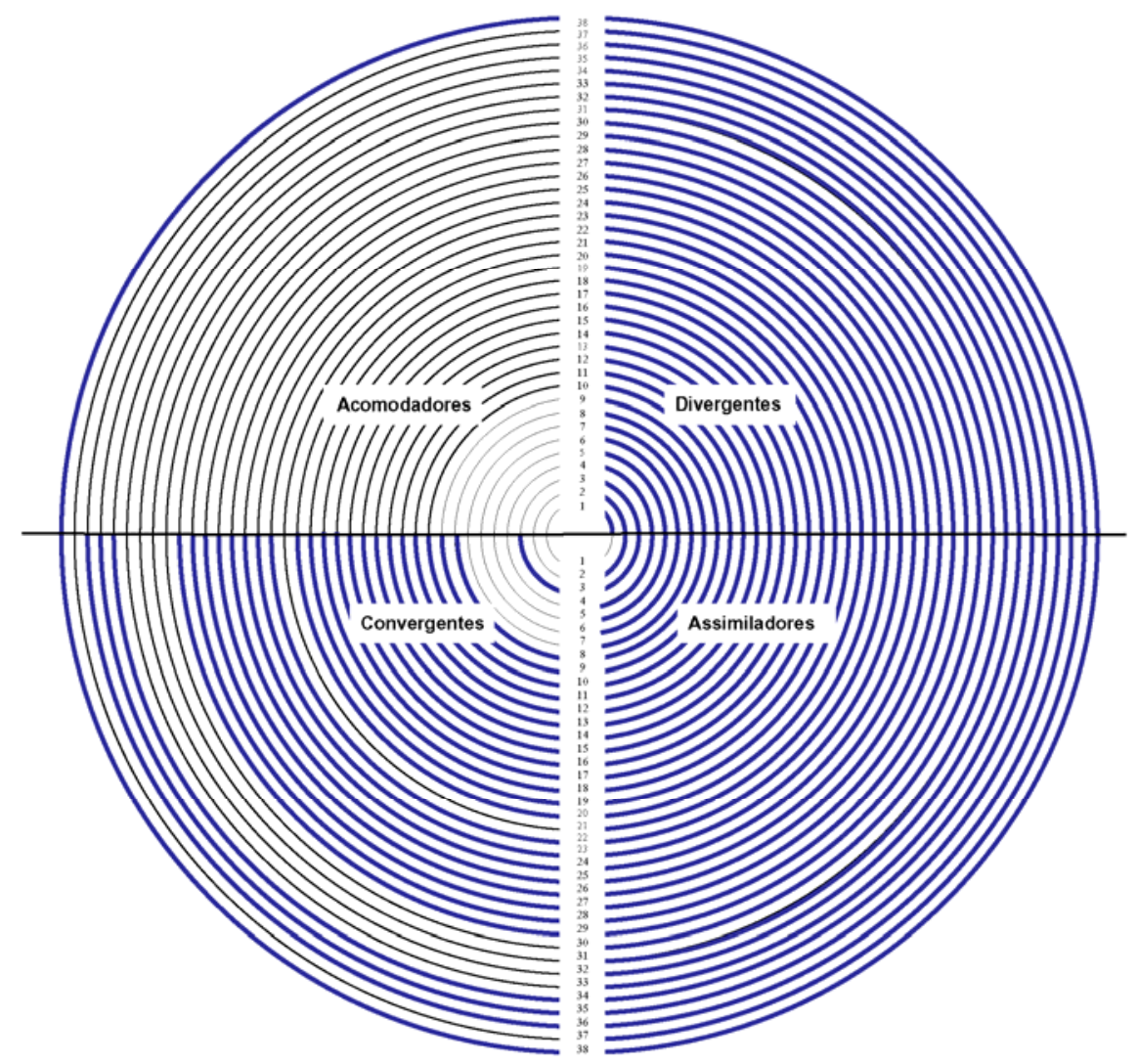

Figura 8.5: Ciclo de aprendizagem do Módulo 1 com as páginas atingidas em cada fase

\section{- Módulo 2}

O segundo módulo do CD apresentou 11 páginas ou slides, como pode ser visto na Figura 8.6. Todas as páginas do módulo (100\%) conduziram o aluno a fase 1 do ciclo, ou seja, atingiram a sua primeira fase do ciclo. Noventa e um por cento conduziram o aluno para a fase 2. Quarenta e cinco por cento das páginas foram atingidas pela fase 3 do ciclo. O ciclo é então encerrado com sua quarta fase, que corresponde ao estilo acomodador e é atingida por $9 \%$ das páginas deste módulo. Completa-se então todo o ciclo, quando este pode ser recomeçado, no próximo módulo. 


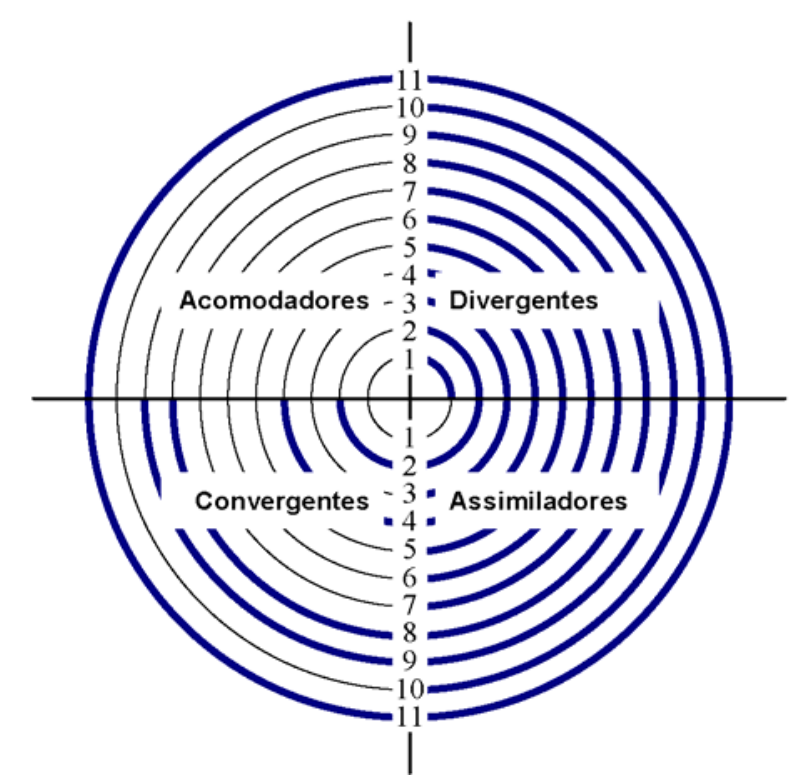

Figura 8.6: Ciclo de aprendizagem do Módulo 2 com as páginas atingidas em cada fase

\section{- Módulo 3}

O terceiro módulo do CD apresentou 50 páginas ou slides (Figura 8.7). Todas as páginas deste módulo (100\%) conduziram o aluno para a fase 1 do ciclo. Noventa e oito por cento das páginas conduziram o aluno para a fase 2 do ciclo, atendendo aos assimiladores. A terceira fase (convergentes) foi atingida por $50 \%$ das páginas e, finalmente, $2 \%$ das páginas conduziram o aluno para a última fase do ciclo, completando-o. 


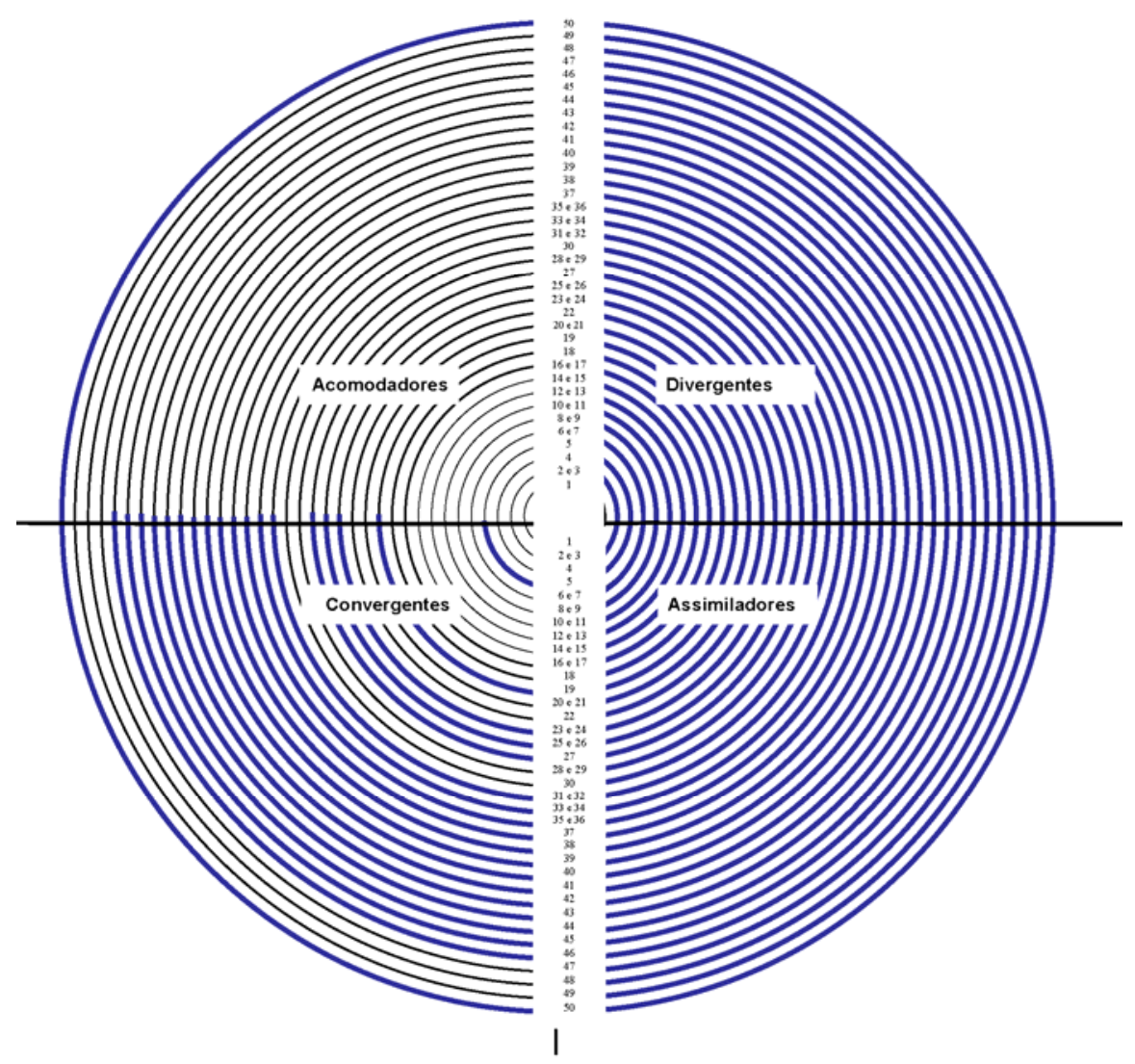

Figura 8.7: Ciclo de aprendizagem do Módulo 3 com as páginas atingidas em cada fase

\section{- Módulo 4}

O quarto módulo do CD apresentou 38 páginas ou slides (Figura 8.8). Cem por cento dessas páginas levaram o aluno para a fase 1 do ciclo, atendendo aos divergentes. Noventa e sete por cento levaram o aluno para a fase 2 do ciclo, atendendo aos assimiladores. Cinqüenta e oito por cento levaram o aluno para a fase 3 do ciclo, atendendo aos convergentes e, finalmente cerca de $3 \%$ das páginas deste módulo levaram o aluno para a quarta fase do ciclo, atendendo aos acomodadores. O ciclo é então encerrado, para ser recomeçado no próximo módulo. 


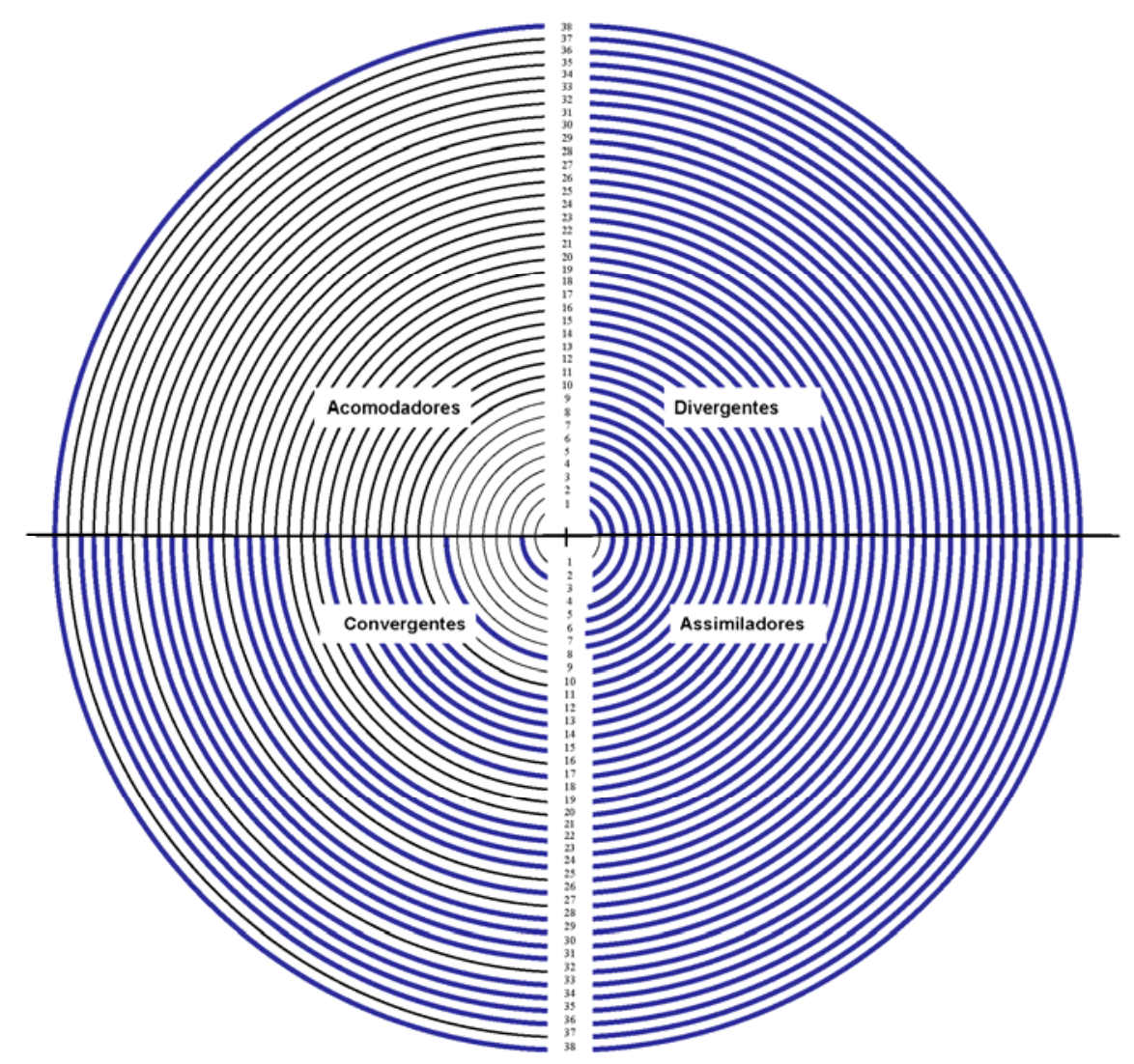

Figura 8.8: Ciclo de aprendizagem do Módulo 4 com as páginas atingidas em cada fase

\section{- Módulo 5}

O quinto módulo do CD apresentou 34 páginas ou slides (Figura 8.9). A fase 1 do ciclo foi atingida por todas as páginas deste módulo (100\%). Noventa e sete por cento das páginas conduziram o aluno para a fase 2 do ciclo, atendendo aos assimiladores. A terceira fase do ciclo (convergentes) foi atingida por $15 \%$ das páginas. O ciclo é então encerrado pela sua quarta fase, que corresponde ao estilo acomodador e é atingido pela página 34 (3\%), completando desta forma todo o ciclo. 


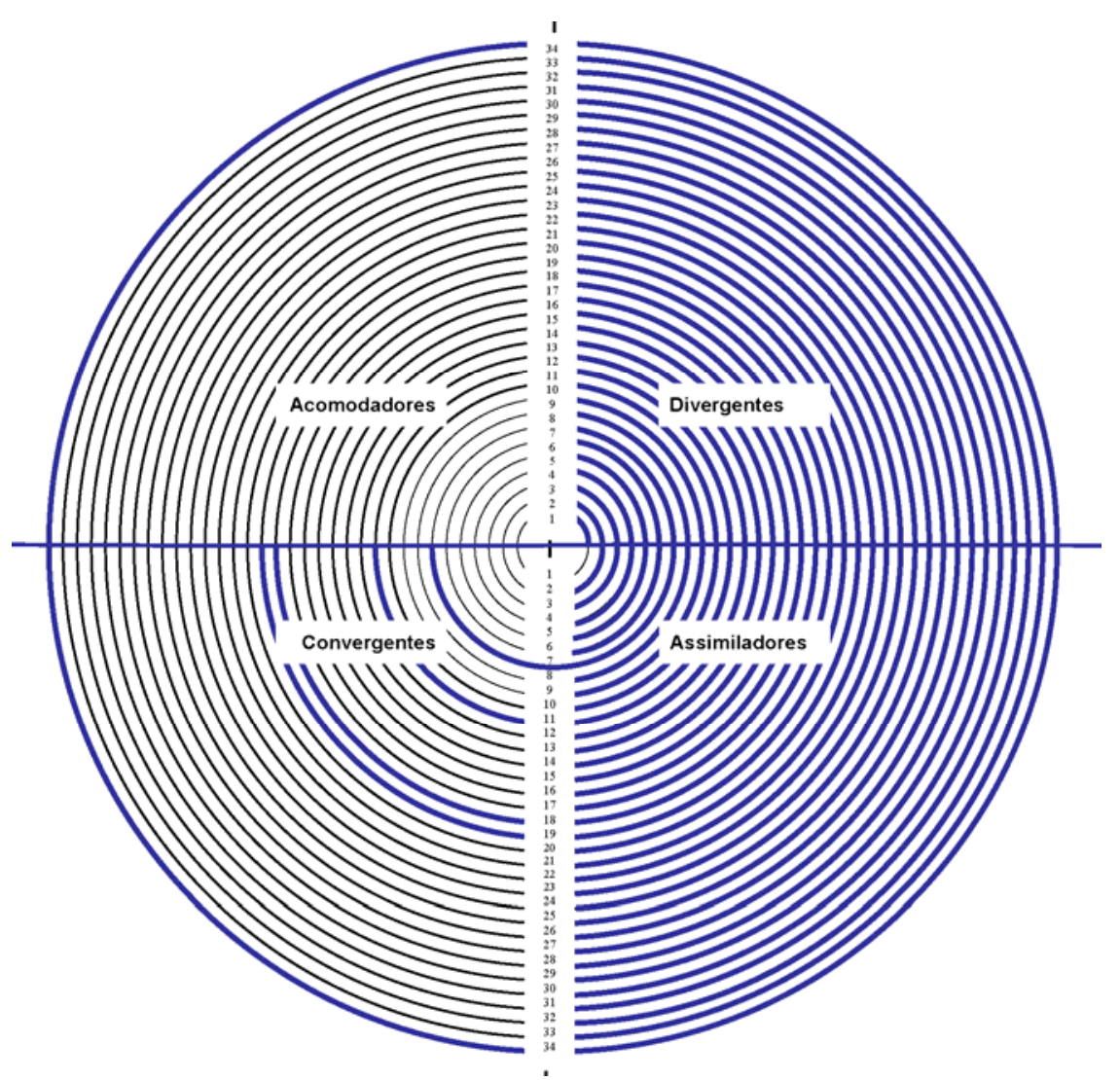

Figura 8.9: Ciclo de aprendizagem do Módulo 5 com as páginas atingidas em cada fase

\section{- Módulo 6}

O sexto módulo apresentou 49 páginas ou slides (Figura 8.10). Cem por cento dessas atenderam aos divergentes (fase 1 do ciclo). Noventa e oito por cento atenderam aos assimiladores (fase 2 do ciclo). Oito por cento atenderam aos convergentes (fase 3 do ciclo). A quarta fase do ciclo, representada pelos acomodadores, foi atingida por $2 \%$ das páginas deste módulo. Desta maneira, o ciclo é encerrado, quando então pode ser recomeçado. 


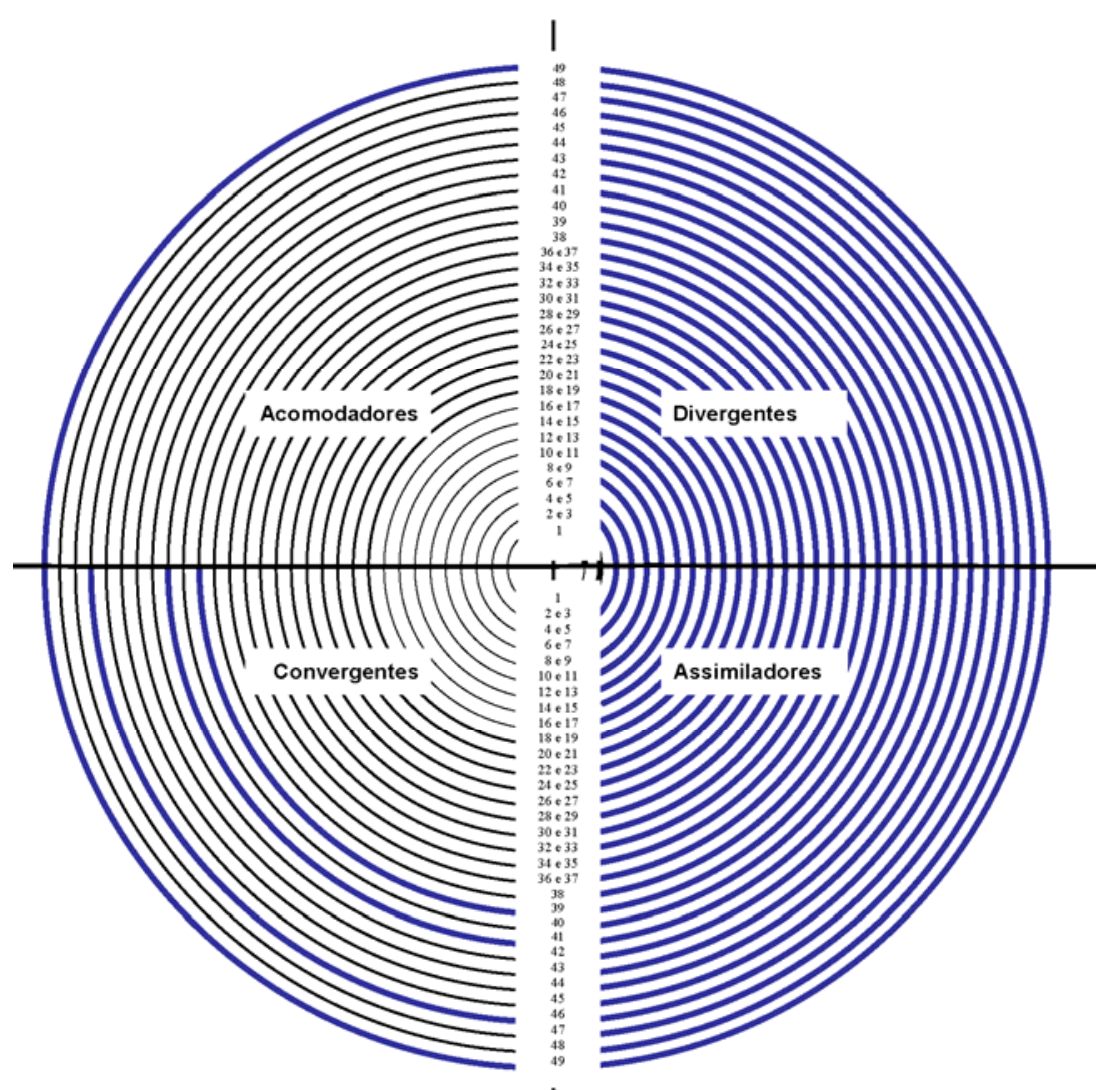

Figura 8.10: Ciclo de aprendizagem do Módulo $6 \mathrm{com}$ as páginas atingidas em cada fase

\section{- Módulo 7}

O sétimo módulo do CD apresentou 46 páginas ou slides (Figura 8.11). A fase 1 do ciclo (divergentes) foi atingida por todas as páginas deste módulo (100\%). A fase 2 do ciclo (assimiladores) foi atingida por $98 \%$ das páginas. Seis por cento dessas atingiram a terceira fase do ciclo (convergentes) e, finalmente, a última fase do ciclo (acomodadores) foi atingida por $2 \%$ das páginas deste módulo, completando, desta maneira, o ciclo. 


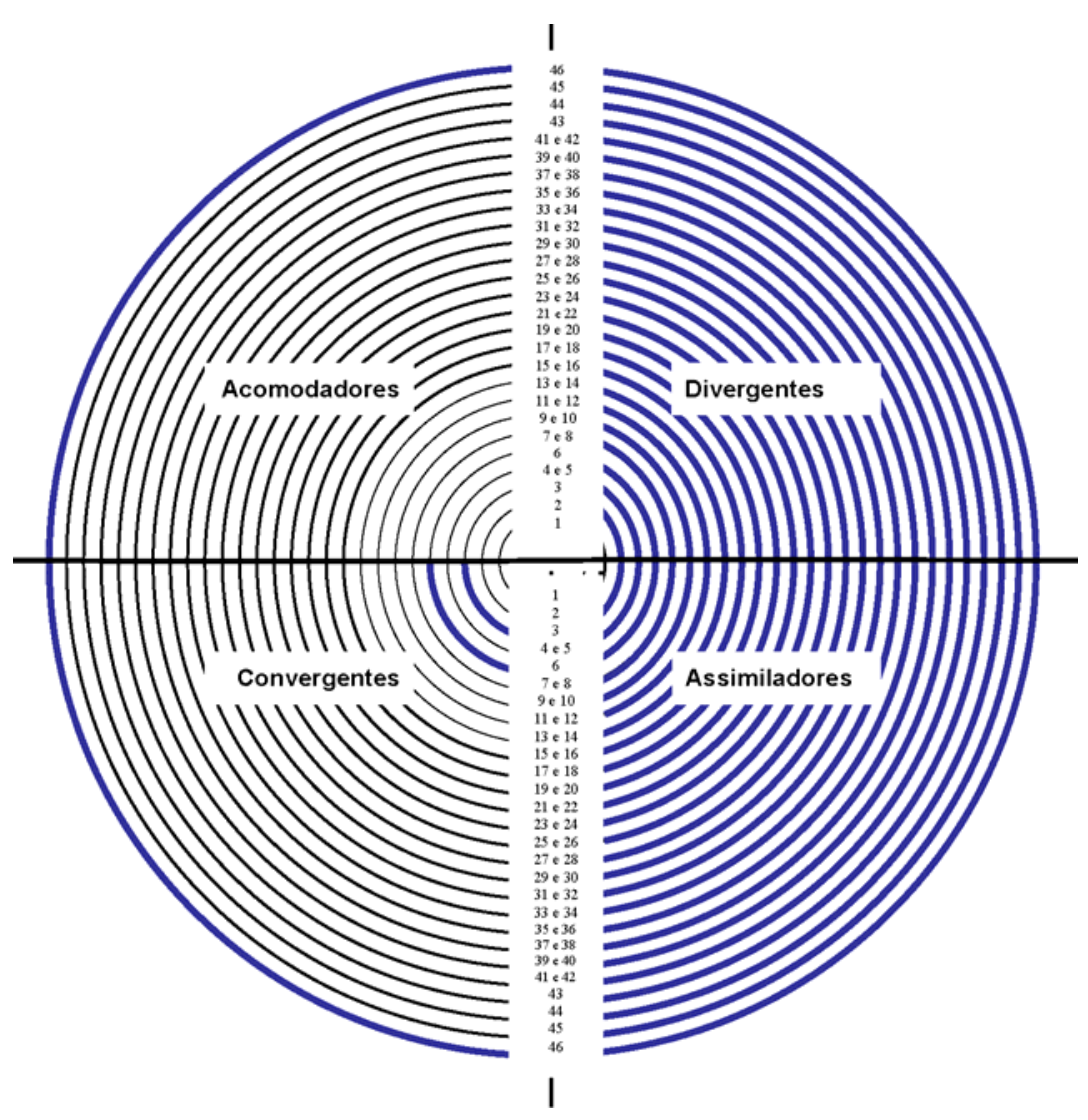

Figura 8.11: Ciclo de aprendizagem do Módulo $7 \mathrm{com}$ as páginas atingidas em cada fase

\section{- Módulo 8}

O oitavo módulo do CD apresentou 39 páginas ou slides (Figuras 8.12). Cem por cento dessas páginas conduziram o aluno para a fase 1 do ciclo, atendendo aos divergentes. Noventa e sete por cento dessas páginas conduziram o aluno para a fase 2 do ciclo, atendendo aos assimiladores. Vinte e um por cento dessas páginas conduziram o aluno para a fase 3 do ciclo, atendendo aos convergentes. A quarta fase foi atingida por cerca de $3 \%$ das páginas deste módulo, onde o ciclo é encerrado e então pode ser recomeçado. 


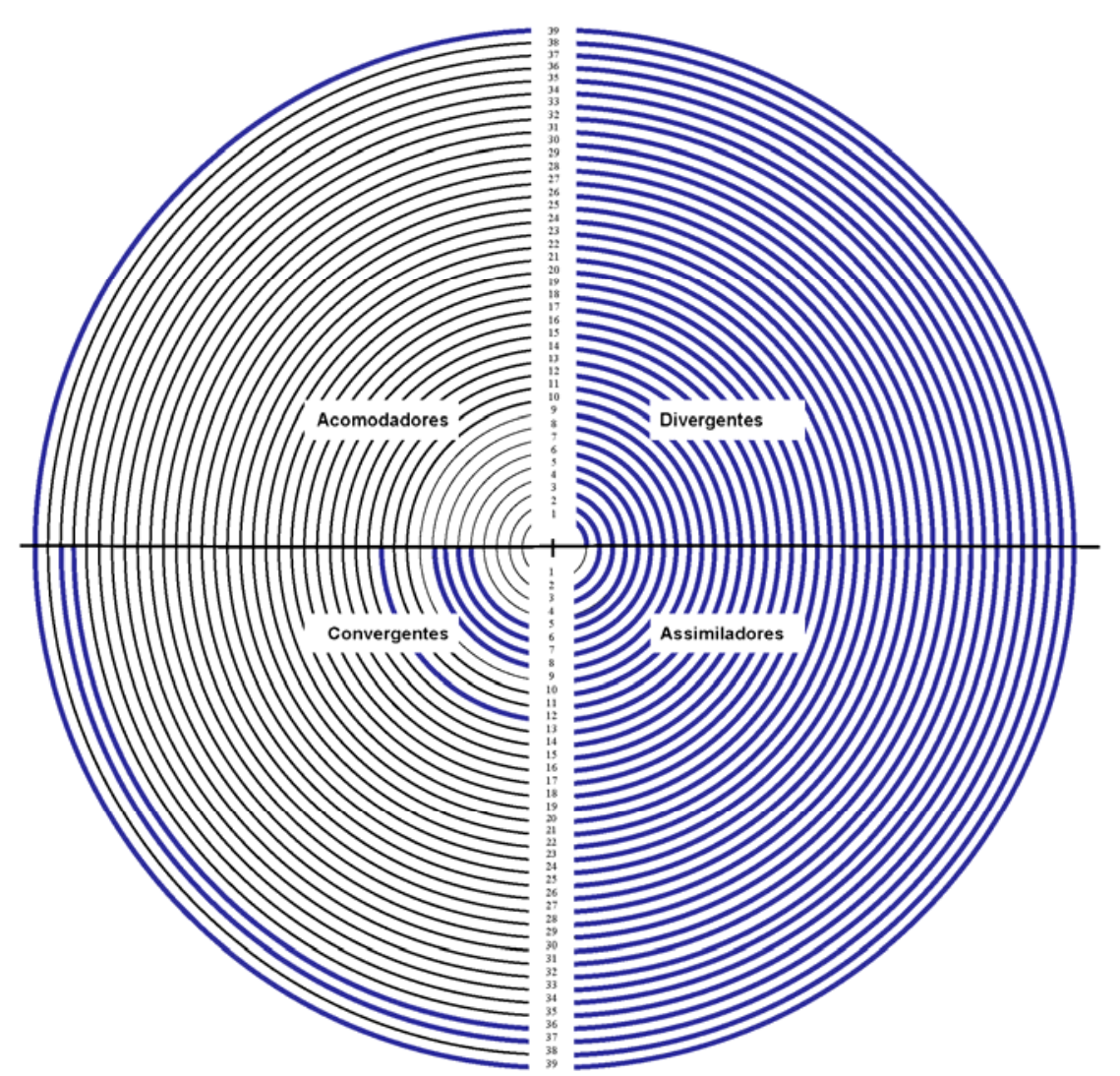

Figura 8.12: Ciclo de aprendizagem do Módulo 8 com as páginas atingidas em cada fase

\section{- Módulo 9}

O último módulo do CD apresentou 60 páginas ou slides (Figura 8.13). Das 60 páginas, $100 \%$ delas conduziram o aluno para a fase 1 do ciclo, atendendo aos divergentes. Noventa e oito por cento delas conduziram o aluno para a fase 2 do ciclo, atendendo aos assimiladores. Quarenta por cento delas conduziram o aluno para a fase 3 do ciclo, atendendo aos convergentes e, finalmente, a quarta fase do ciclo foi atendida por cerca de $2 \%$ das páginas deste módulo, atendendo assim aos acomodadores. 


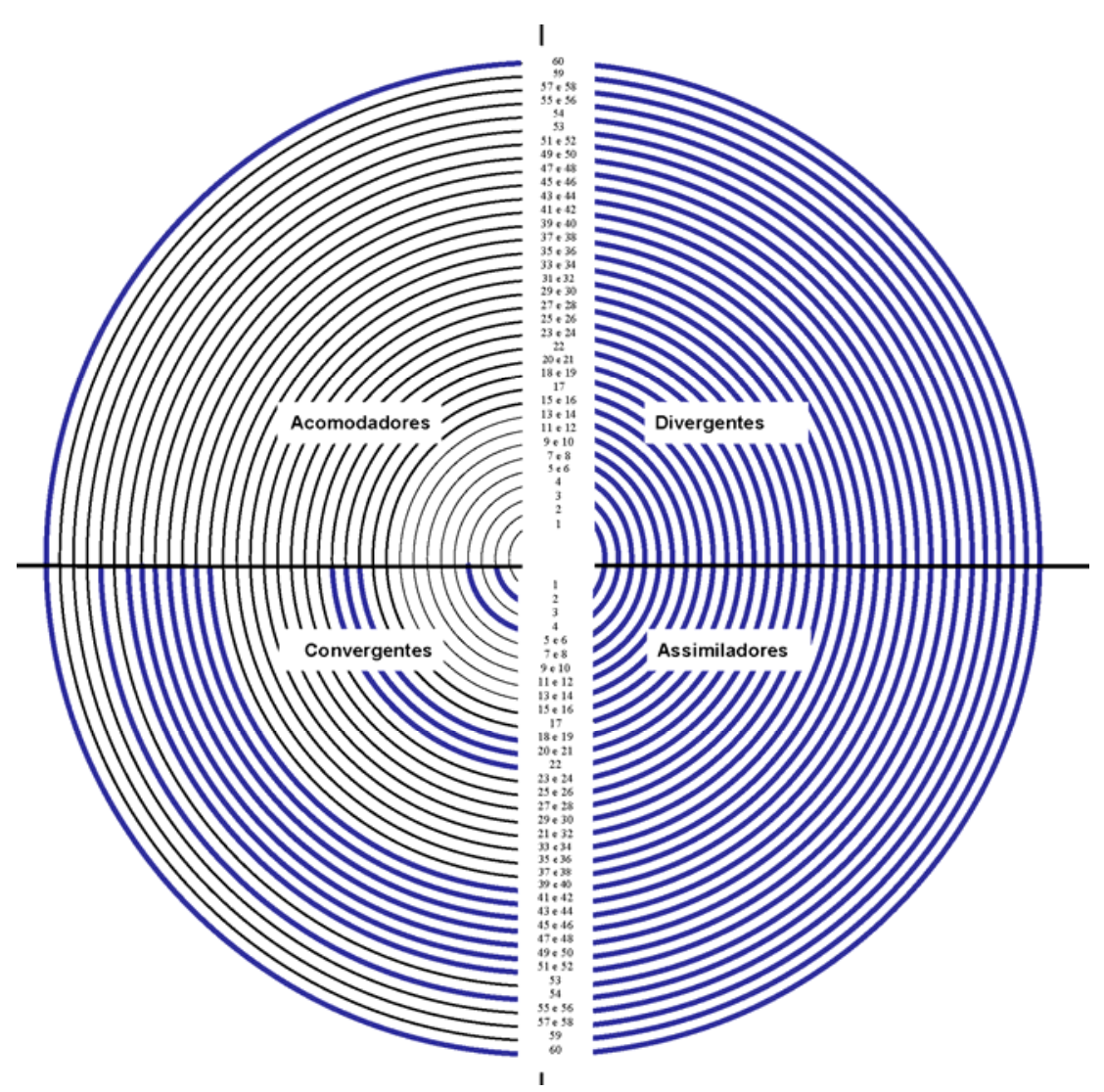

Figura 8.13: Ciclo de aprendizagem do Módulo $9 \mathrm{com}$ as páginas atingidas em cada fase

Diante do que foi apresentado, pôde-se constatar que o objetivo de atingir todos os quatro estilos de aprendizagem do modelo de Kolb na elaboração do CD, foi alcançado, visto que todos os nove módulos completaram o ciclo.

A construção dos módulos, tendo como base o modelo de Kolb, mostrou que o uso de diferentes mídias e criatividade nos conteúdos oferecidos aos alunos torna possível atingir os quatro estilos de aprendizagem, em tese satisfazendo assim a todos os tipos de alunos.

\subsection{Análise da Aplicação do Modelo da Taxonomia de Bloom}

Como visto anteriormente, este modelo se aplica para a análise de resultados educacionais ligados a área cognitiva. Fizeram parte dessa avaliação os quarenta alunos ( $n=40$ ) que cursaram em 2004, a disciplina "Planejamento e Análise de Sistemas de Transportes" oferecida no terceiro ano do curso de Engenharia Civil. Os alunos foram divididos em oito grupos, onde cada grupo 
ficou responsável pela apresentação de uma técnica específica.

Sabendo-se que o seminário é uma técnica de ensino bastante utilizada para avaliar conceitos e idéias e que a classificação de Bloom analisa essa área congnitiva, ela foi aplicada, através do professor da disciplina, conforme visto no item 7.1.3, obtendo-se os resultados observados na Tabela 8.3.

Tabela 8.3: Resultado da avaliação feita pela Taxonomia de Bloom

\begin{tabular}{|l|c|c|c|c|c|c|}
\hline \multirow{2}{*}{ Técnicas / Grupos } & \multicolumn{5}{c|}{ Níveis OU Categorias } \\
\cline { 2 - 7 } & Conhecimento & Compreensão & Aplicação & Análise & \multirow{2}{*}{ Síntese } & \multirow{2}{*}{ Avaliação } \\
\hline RNA - A & Totalmente & Parcialmente & Parcialmente & Totalmente & Quase Nada & Não avaliado \\
\hline Lógica Fuzzy - B & Totalmente & Totalmente & Parcialmente & Parcialmente & Parcialmente & Não avaliado \\
\hline Algoritmos Genéticos - C & Totalmente & Parcialmente & Quase Nada & Parcialmente & Quase Nada & Não avaliado \\
\hline SIG - D & Totalmente & Parcialmente & Quase Nada & Quase Nada & Nada & Não avaliado \\
\hline Avaliação Multicritério - E & Totalmente & Parcialmente & Quase Nada & Parcialmente & Quase Nada & Não avaliado \\
\hline Autômatos Celulares - F & Totalmente & Totalmente & Parcialmente & Parcialmente & Quase Nada & Não avaliado \\
\hline Simulated Annealing - G & Totalmente & Parcialmente & Quase Nada & Parcialmente & Quase Nada & Não avaliado \\
\hline Estatística Espacial - H & Totalmente & Parcialmente & Parcialmente & Parcialmente & Quase Nada & Não avaliado \\
\hline
\end{tabular}

Como pode ser observado na Tabela 8.3, o Nível 1 (Conhecimento) foi plenamente atingido por todos os grupos. Isso significa dizer que todos atingiram muito bem a fase da repetição. Entretanto, este é o nível mais baixo da classificação de Bloom.

Os Níveis 2 e 3, que são considerados os níveis da compreensão e aplicação, respectivamente, foram alcançados por todos os grupos, de maneira total a parcial (vide tabela), mostrando que todos saíram da fase da repetição e passaram para a fase da formação de conceitos. Isso significa que os alunos compreenderam o que aprenderam, de modo a afirmá-lo de forma diferente. Por exemplo, eles passam a citar exemplos diferentes dos que já tinham visto.

O Nível 4 (Análise) foi atingido com totalidade apenas pelo grupo A (RNA). Isso significa que esses alunos foram capazes de identificar as partes ou a estrutura de um todo de forma completa, sem dúvidas. Os grupos B, C, F, G e H também alcançaram esse nível, entretanto de forma parcial. Apenas o grupo $D(S I G)$ não atingiu a categoria Análise de forma minimamente satisfatória. 
Quando se passa para o Nível 5 (Síntese) o segundo nível mais alto da classificação de Bloom, apenas o Grupo B (Lógica Fuzzy) atingiu o Nível 5 de forma razoável (parcial). Todos os demais grupos não conseguiram alcançar a fase da criatividade; fase específica dos níveis 5 e 6 e também os mais altos da classificação de Bloom.

O nível ou categoria 6 (Avaliação) da classificação de Bloom não pôde ser avaliado pelo professor apenas com a apresentação do seminário.

Diante deste contexto, pôde-se observar, através da avaliação apresentada, que a maioria dos alunos atingiram até o Nível 4 da classificação de Bloom, nível este já bastante satisfatório para ter sido alcançado diante dos assuntos inovadores (do ponto de vista de alunos de gradução em engenharia civil) abordados em quinze minutos através de seminário. Pode-se afirmar também que o modelo de classificação da Taxonomia de Bloom mostrou-se eficiente para este tipo de avaliação.

\subsection{Análise dos Dados Qualitativos}

Conforme foi visto no capítulo 06 , avaliações qualitativas foram obtidas a partir das respostas às questões dissertativas, das respostas de auto-avaliação dos seminários, das respostas das avaliações feitas pelos alunos e pelo professor dos seminários e através das respostas dada pelo professor com a utilização do modelo de classificação denominado Taxonomia de Bloom. Outra forma de avaliação qualitativa aplica-se à proposta de utilizar O CD como forma de facilitar a aprendizagem. Cada um desses casos será analisado a seguir.

\subsubsection{Análise das questões dissertativas}

Conforme visto no capítulo "Método do Trabalho", vinte dos quarenta alunos receberam questões de cunho dissertativo. Estas questões tinham o objetivo de fazer o aluno buscar novos conhecimentos, que ainda não tinham sido visto em sala de aula. Nesta etapa, os alunos teriam que elaborar uma questão dissertativa que associasse o módulo estudado a alguma técnica emergente ou ao tema Desenvolvimento Sustentável, indicando ainda a página da Internet 
que foi utilizada. A elaboração dessa questão deveria ser feita ao término de cada módulo.

Pode-se dizer que a grande maioria dos vinte alunos selecionados respondeu às questões referentes aos nove módulos (76,67\% dos alunos). Esse índice pode ser considerado alto, tendo em vista também a qualidade das respostas recebidas. Após a avaliação de cada uma das questões recebidas, acredita-se ter sido um bom resultado, mostrando que os alunos têm capacidade para buscar novos conhecimentos, bastando o professor saber explorá-los.

Ao final do curso, todos os quarenta alunos receberam uma questão (apresentada no capítulo 6) onde era perguntado se eles já tinham ouvido falar da técnica Redes Neurais Artificiais (RNA) e sobre o tema Desenvolvimento Sustentável. Se o aluno tivesse uma resposta afirmativa, era necessário desenvolver o tema, em no máximo dez linhas. O resultado dessa avaliação pode ser vista na Tabela 8.4 .

Tabela 8.4: Avaliação do recurso utilizado para detecção de absorção ou não do conhecimento

\begin{tabular}{lll}
\hline & $\begin{array}{l}\text { Alunos que } \\
\text { participaram da } \\
\text { experiência }(n=20)\end{array}$ & $\begin{array}{l}\text { Alunos fora da } \\
\text { experiência }(n=20)\end{array}$ \\
\hline $\begin{array}{l}\text { Ouviram falar da técnica ou tema } \\
\text { Não ouviram falar da técnica ou }\end{array}$ & $19(95 \%)$ & $17(85 \%)$ \\
tema & $14(70 \%)$ & $3(15 \%)$ \\
$\begin{array}{l}\text { Descreveram sobre os assuntos } \\
\text { Não descreveram sobre os assuntos }\end{array}$ & $6(30 \%)$ & $6(30 \%)$ \\
\hline
\end{tabular}

De acordo com a Tabela 8.4 pode-se observar que a maioria dos alunos já tinha ouvido falar da técnica Redes Neurais Artificiais ou do tema Desenvolvimento Sustentável, o que, para uma amostra de alunos de graduação em engenharia civil, já é satisfatório.

Ainda na mesma Tabela, observa-se que a metade da turma que foi submetida a experiência (aqueles que resolveram as questões dissertativas) saíram-se bem melhor para comentar sobre os temas no final do curso $(70 \%$ descreveram sobre os assuntos), contrastando com $30 \%$ da outra turma. 
Mesmo que de maneira subjetiva, pôde-se constatar, através desta avaliação, que o fato do próprio o aluno buscar novos conhecimentos ainda não vistos em sala de aula, o torna capaz de absorver algum conteúdo, a ponto mesmo de discutir sobre o assunto.

\subsubsection{Análise do seminário}

Para poder fazer uma análise dos seminários, eles foram avaliados de quatro maneiras: uma avaliação feita pelos alunos, uma avaliação feita pelo professor, uma auto-avaliação e uma avaliação utilizando o modelo de classificação denominado Taxonomia de Bloom.

\subsubsection{Avaliação feita pelos alunos}

Cada aluno recebeu uma planilha (Anexo B) para avaliar o grupo que estava apresentando o seminário, considerando os seguintes fatores: clareza nos conteúdos, coerência entre os tópicos, postura profissional, domínio do tema e material de apoio utilizado, da seguinte forma:

Fator Clareza: "Os conteúdos foram ministrados de forma clara". Fator Coerência: "Houve coerência dos diferentes tópicos do seminário entre si e em relação ao conteúdo do curso".

Fator Postura: "A postura do(s) apresentador(es) pode ser considerada séria e profissional".

Fator Domínio: "A apresentação (escrita e oral) demonstra domínio do tema".

Fator Material de Apoio: "O material de apoio está bem elaborado, tratando do tema proposto de forma concisa (dentro do tempo proposto), mas sem perder a clareza".

Os resultados obtidos por grupo, podem ser vistos através das Figuras abaixo. As Figuras 8.15 até 8.22 seguem a legenda mostrada abaixo.

Concordo Totalmente

Concordo

Nẫo Sei

Discordo

Discordo Totalmente 


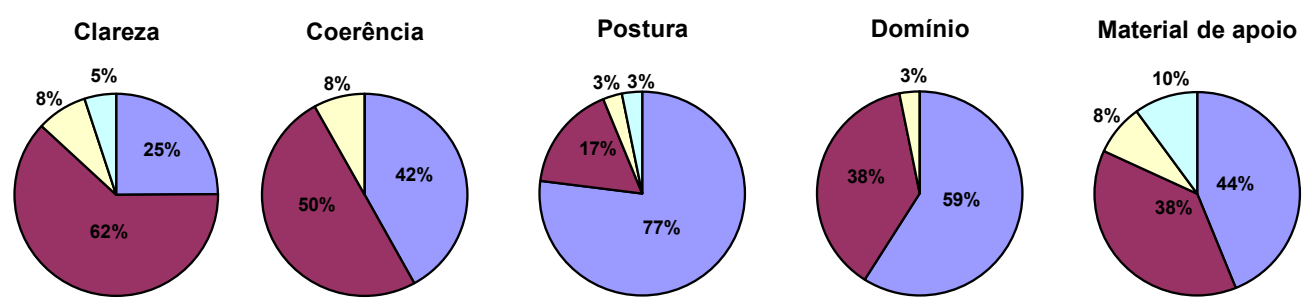

Figura 8.14: Avaliação feita pelos alunos para o Grupo A (Redes Neurais Artificiais)
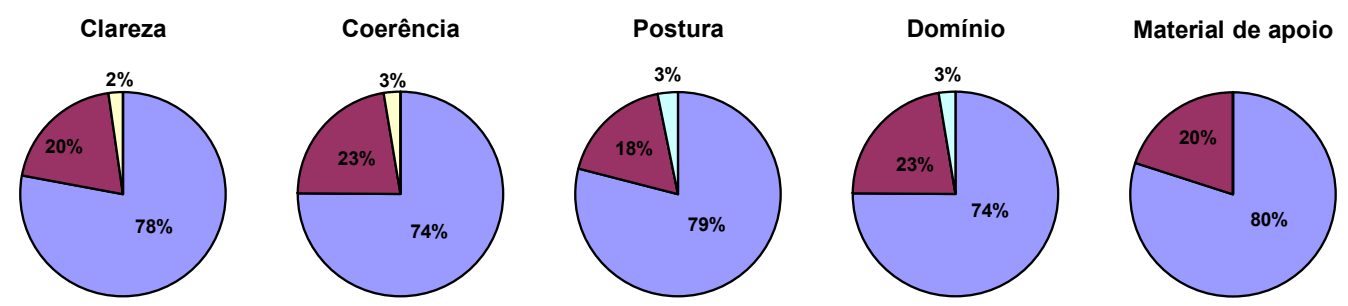

Figura 8.15: Avaliação feita pelos alunos para o Grupo B (Lógica Fuzzy)
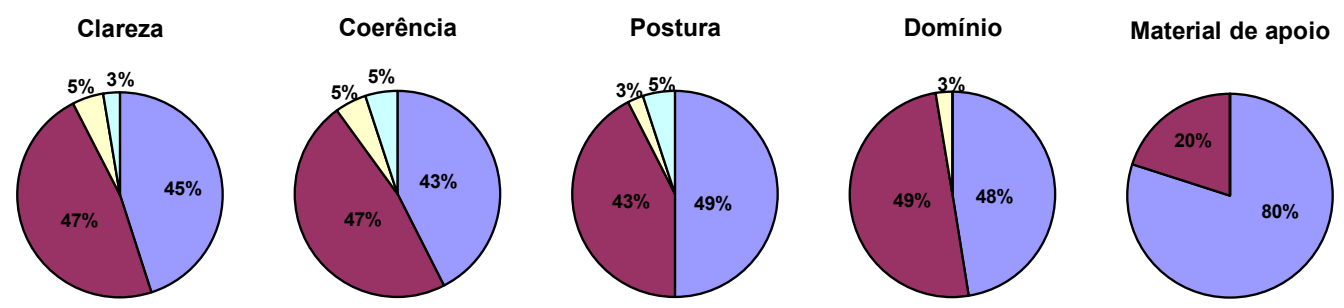

Figura 8.16: Avaliação feita pelos alunos para o Grupo C (Algoritmos Genéticos)
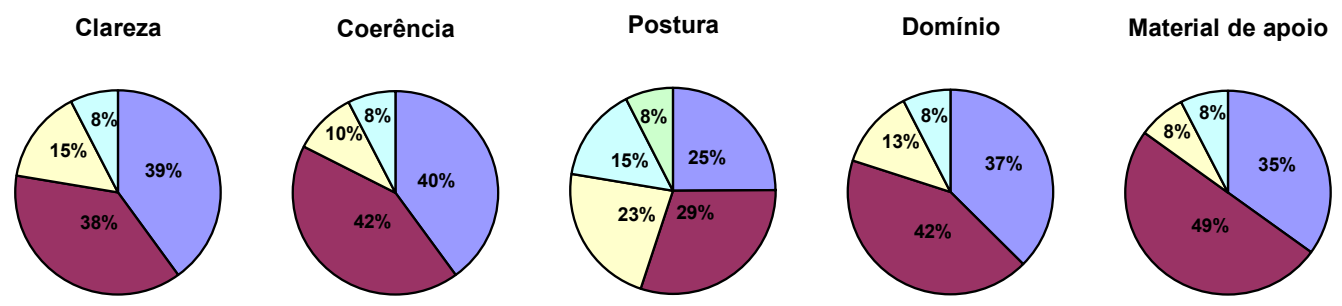

Figura 8.17: Avaliação feita pelos alunos para o Grupo D (Sistemas de Informação Geográfica - SIG) 

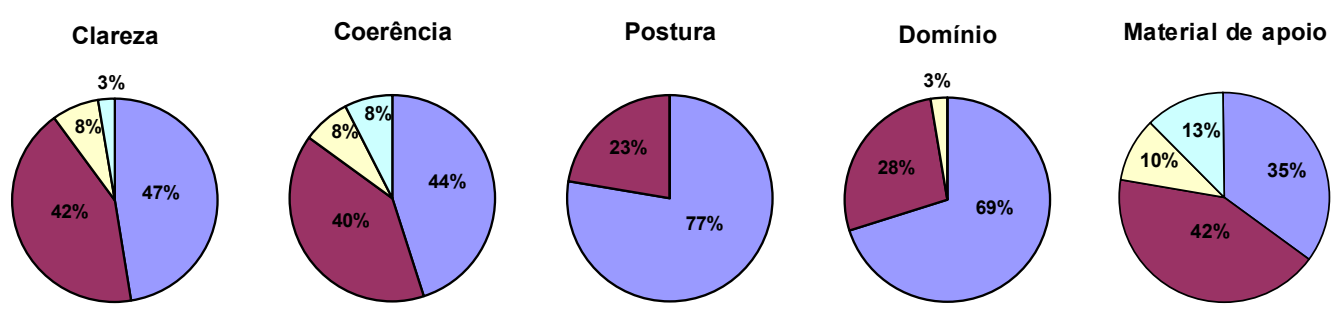

Figura 8.18: Avaliação feita pelos alunos para o Grupo E (Avaliação Multicritério)
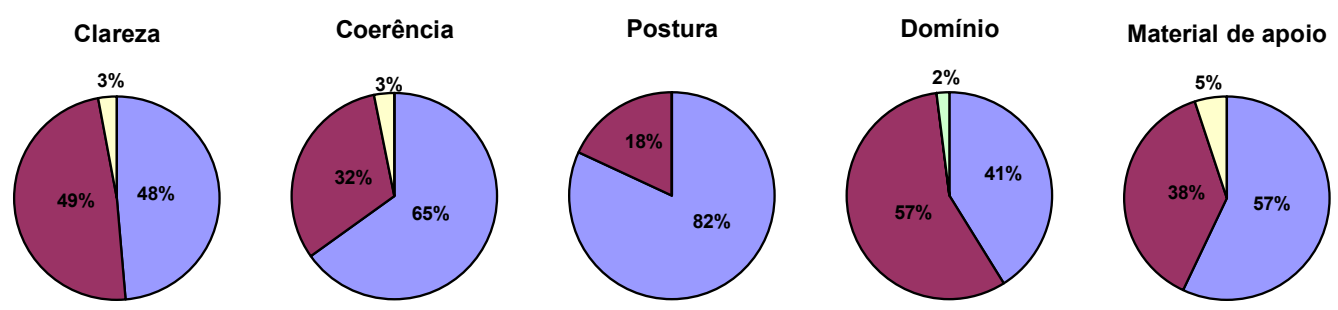

Figura 8.19: Avaliação feita pelos alunos para o Grupo F (Autômatos Celulares)
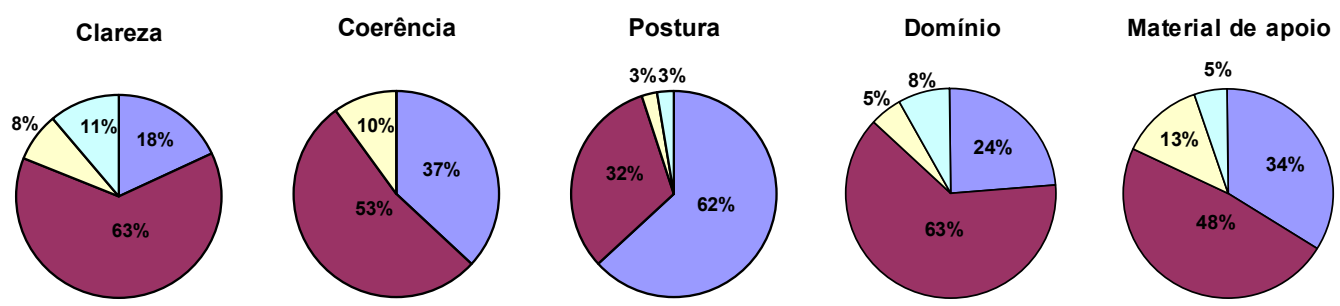

Figura 8.20: Avaliação feita pelos alunos para o Grupo G (Simulated Annealing)
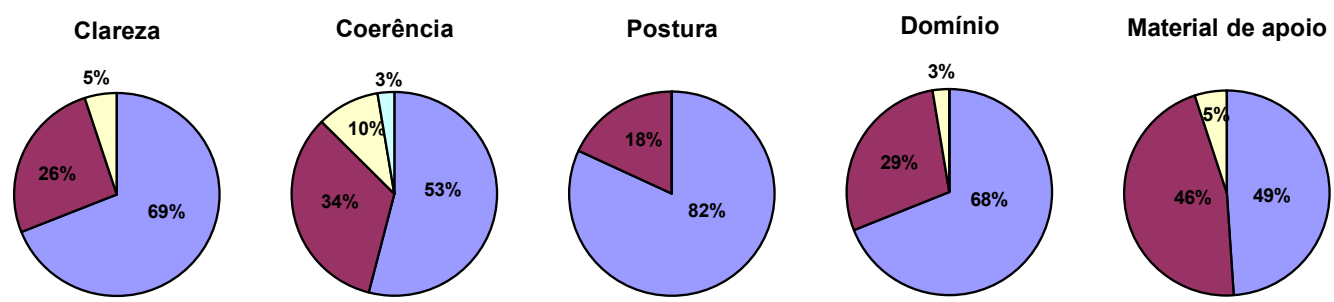

Figura 8.21: Avaliação feita pelos alunos para o Grupo H (Estatística Espacial)

Através da avaliação feita pelos alunos pode-se constatar que o grupo que apresentou as maiores percentagens para boa clareza, coerência, postura, domínio e utilização de material de apoio, de maneira geral, foi o grupo Lógica Fuzzy. Em contrapartida, o grupo que apresentou os menores resultados para os fatores avaliados pelos alunos foi o Simulated Annealing e SIG. 


\subsubsection{Avaliação feita pelo professor}

A mesma planilha utilizada pelos alunos foi também usada pelo professor para a avaliação dos seminários. Os resultados obtidos por fator analisado são mostrados na Figura 8.23.

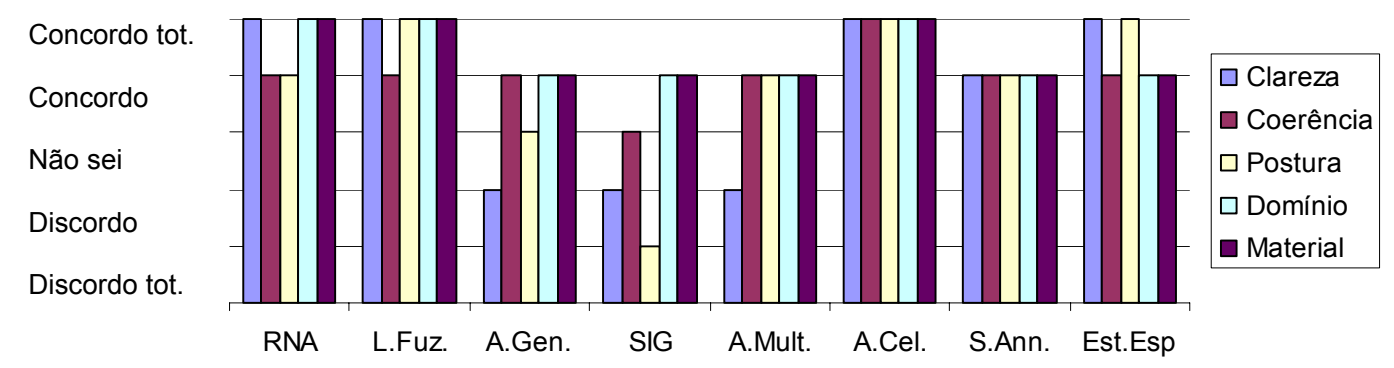

Figura 8.22: Avaliação feita pelo professor para todos os grupos e para todos os fatores

Com a avaliação dada pelo professor da disciplina, observa-se que o grupo que apresentou melhor desempenho médio entre todos os fatores analisados foi o grupo representado pela técnica "Autômatos Celulares", que se mostra ligeiramente diferente da avaliação feita pelos alunos que apontaram Lógica Fuzzy como o melhor grupo (segundo na classificação do professor). O grupo que apresentou um desempenho pouco satisfatório foi o " $D$ ", Sistemas de Informação Geográfica, diferente também da avaliação feita pelos alunos, que acusou além desse, o grupo "Simulated Annealing".

\subsubsection{Auto-avaliação}

Os alunos também tiveram a oportunidade de avaliar seus próprios grupos durante os seminários. Os resultados obtidos por fator e por grupo analisado são mostrados na figura abaixo.

Através desta avaliação, mostrada na Figura 8.24 , constata-se que poucos foram os grupos que atribuíram notas máximas para si mesmos. A maioria dos grupos teve uma postura de autocrítica, como por exemplo, os grupos: Algoritmos Genéticos, SIG, Avaliação Multicritério, Simulated Annealing e Estatística Espacial, mostrando desta forma, profissionalismo e seriedade com a avaliação. 


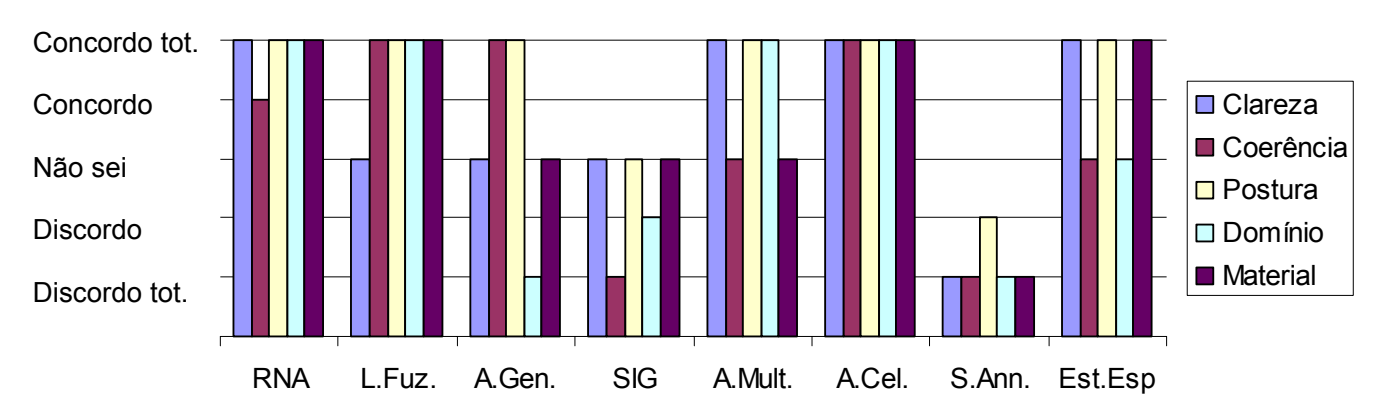

Figura 8.23: Auto-avaliação feita pelos alunos para seus grupos

A avaliação e análise feita pelo professor através do modelo de classificação denominado Taxonomia de Bloom já foi apresentada no item 8.4.

\subsubsection{Análise das preferências de aprendizagem dos alunos}

A última forma apresentada nesta pesquisa para uma avaliação através do método qualitativo foi obtida através de uma análise a uma das questões oferecidas aos alunos através do software WebCT. Ao final de cada módulo do $C D$, o aluno era convidado a resolver testes de conhecimento relacionadas ao tema estudado, disponíveis no site do curso. A primeira questão deste teste não estava relacionada ao conhecimento específico do tema, mas sim, era perguntado aos alunos sobre como eles tinham acompanhado aquele módulo específico da disciplina. Os alunos tinham cinco opções para resposta (Tabela 8.5).

Como a turma era de 40 alunos e estava sempre disponível um teste para cada módulo (ou seja, 9 testes), a expectativa de recebimento dessa questão específica era de 360 respostas. Entretanto, foram recebidas 212 respostas (60\%). A Tabela 8.4 apresenta em termos percentuais as preferências dos alunos na escolha das suas aprendizagens, com base nestas 212 respostas. 
Tabela 8.5: Resultado apresentado pelos alunos sobre suas preferências de aprendizagem com relação aos recursos utilizados pelo professor

\begin{tabular}{lc}
\hline Método preferido & (\%) de Alunos \\
\hline Através das aulas e do CD & $\mathbf{5 7}$ \\
Exclusivamente através das aulas & 13 \\
Exclusivamente através do CD & 6 \\
Utilizando mais o CD do que as aulas propriamente ditas & 13 \\
Através das aulas mais do que utilizando o CD & 11 \\
\hline
\end{tabular}

Nesta pesquisa foi apresentada aos alunos, durante todo o curso, recursos e mídias (como o fornecimento do $C D$ educativo elaborado) paralelamente às aulas, a fim de torná-las mais atrativas do que as aulas tradicionais. Os resultados apresentados através da Tabela 8.5 mostram que a maioria dos respondentes (57\%) prefere uma aprendizagem balanceada entre o que é dado em sala de aula (método tradicional) e algum recurso inovador, como foi o caso do CD (diferente do tradicional).

Em contrapartida, observa-se que, no caso desta pesquisa, os alunos ainda não se sentem seguros em abandonar totalmente o aprendizado dado nas aulas para começarem a aprenderem, por exemplo, apenas através de um documento hipermídia apresentado a eles (apenas $6 \%$ das respostas recebidas utilizaram apenas o CD para aprimorar seu aprendizado nas provas e testes).

Estes resultados confirmam o que foi dito neste trabalho com relação a aplicar uma metodologia b-learning para contribuir com a obtenção da melhoria no processo de ensino-aprendizagem, combinando assim, os métodos tradicionais e inovadores de ensino. Outras observações a esse respeito serão tratadas no capítulo "Considerações Finais".

\subsection{Análise dos Dados Quantitativos}

Conforme visto na literatura, os métodos quantitativos consistem basicamente na comparação sistemática de qualidades e permitem a análise estatística de relações. Assim sendo, a avaliação e posterior análise quantitativa será obtida através de quatro maneiras: registro automático, histórico de desempenho dos 
alunos, comparação do desempenho dos alunos quanto a formulação das provas aplicadas e comparação do desempenho feito através das médias da nota final das duas turmas de 2004 (aquela que continuou utilizando a abordagem tradicional com a turma que realizou a aprendizagem através do novo paradigma proposto. Cada uma dessas avaliações será mostrada a seguir.

\subsubsection{Registro automático}

Este tipo de avaliação quantitativa já foi mencionado brevemente no item 8.1, por essa razão aqui serão apresentadas mais algumas observações.

O software educativo WebCT fornece um relatório de acompanhamento (Vide Figura 8.1 do item 8.1) com o qual pode-se obter resultados da participação dos alunos das páginas navegadas no software. De posse dos dados dessa Tabela, pôde-se identificar os resultados mostrados na Tabela 8.6.

Tabela 8.6: Percentagem de alunos que acessaram as páginas do site, de acordo com o número de visitas

\begin{tabular}{cc}
\hline Número de visitas & $(\%)$ de alunos \\
\hline De 0 a 50 & 19,50 \\
De 51 a 100 & 48,80 \\
De 101 a 150 & 9,75 \\
De 151 a 200 & 12,20 \\
Acima de 200 & 9,75 \\
\hline
\end{tabular}

Com os resultados apresentados na Tabela 8.6 pode-se ter uma idéia de como foi a navegação dos alunos pelo site WebCT. Sabe-se, por exemplo, que a maioria dos alunos $(80.50 \%)$ visitaram as páginas do site mais de 50 vezes.

Em síntese, constata-se que a avaliação feita através do registro automático fornecido pelo WebCT mostrou-se, através dos resultados apresentados, satisfatória, visto que o site foi bastante visitado. Outra constatação é que, levando-se em consideração as outras atividades profissionais e pessoais que cada aluno possui, ainda assim o site não deixou de ser visitado de forma sistemática. 


\subsubsection{Histórico de desempenho dos alunos}

Outra forma de avaliação pelo método quantitativo foi a comparação de desempenho dos alunos que cursaram essa mesma disciplina "Planejamento e Análise de Sistemas de Transportes" com os mesmos professores, no decorrer dos dez últimos anos, ao longo do quais o processo de ensino-aprendizagem era realizado através do método tradicional. Não foram incluídos neste conjunto, no entanto, os anos de 1996 e 2002, pelo fato de que um dos professores regulares, por motivo de viagem, não ministrou o curso naqueles anos. Cabe observar que a disciplina citada acima, oferecida pelo Departamento de Transportes da Escola de Engenharia de São Carlos, sempre foi lecionada por dois professores do departamento, sendo usualmente um deles o orientador desta pesquisa.

A amostra deste trabalho foi constituída por quarenta dos sessenta alunos que foram matriculados na disciplina "Planejamento e Análise de Sistemas de Transportes" oferecida no segundo semestre do terceiro ano do curso de Engenharia Civil. Essa disciplina vem sendo ministrada por dois docentes do Departamento de Transportes da Escola de Engenharia de São Carlos, sempre dividida em partes iguais para os dois professores (em torno de 30 alunos em cada turma). Excepcionalmente para o ano de 2004 a turma foi separada em partes diferentes (40/20) para que a amostra deste trabalho fosse mais significativa $(n=40)$ e se pudesse dispor de um Grupo Experimental.

Assim sendo, quarenta alunos trabalharam durante todo o curso com mudanças no processo de ensino-aprendizagem ( $C D$ educativo, trabalhos em grupo, Internet, WebCT, etc.), enquanto que os outros vinte alunos tiveram uma abordagem tradicional de ensino. A Tabela 8.7 mostra as médias finais dos últimos anos (exceto os anos de 1996 e 2002, já citados) e para o ano de 2004 desses 40 alunos. 
Tabela 8.7: Médias das notas finais dos últimos anos dos alunos que freqüentaram a disciplina "Planejamento e Análise de Sistemas de Transportes"

\begin{tabular}{ccc}
\hline Ano & Média das Notas Finais & Desvio Padrão \\
\hline 1994 & 5,39 & 1,26 \\
1995 & 5,97 & 2,13 \\
1997 & 6,69 & 1,94 \\
1998 & 6,05 & 1,96 \\
1999 & 6,05 & 1,64 \\
2000 & 6,52 & 1,17 \\
2001 & 6,21 & 1,31 \\
2003 & 6,11 & 1,08 \\
Média & $\mathbf{6 , 1 2}$ & $\mathbf{1 , 5 6}$ \\
$\mathbf{2 0 0 4}$ & 6,90 & 1,30 \\
\hline
\end{tabular}

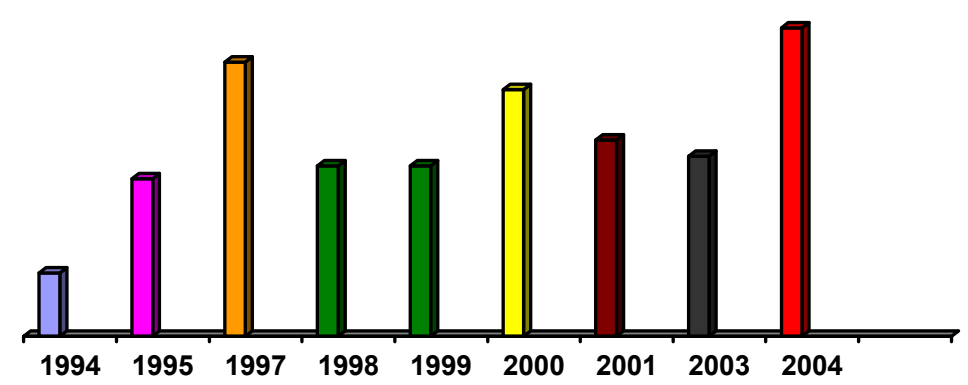

Figura 8.24: Média das notas finais dos últimos anos dos alunos que freqüentaram a disciplina "Planejamento e Análise de Sistemas de Transportes"

De acordo com a Tabela 8.7 (ilustrada pela Figura 8.24), observa-se que a média das notas do ano de 2004, ano em que foram feitas as mudanças na metodologia de ensino, com a inserção das alternativas pedagógicas mostradas neste trabalho, foi a maior de todos os anos considerados $(6,90)$. Esta média foi $11 \%$ superior à média dos oito últimos anos $(6,12)$. Além disso, também apresentou um desvio padrão de 1,30, o quarto menor desvio dentre os dados apresentados.

Cabe ressaltar que não foi possível realizar uma análise estatística dos dados apresentados na Tabela 8.7, visto que esses não representam uma amostra homogênea. Até o ano de 2002, a disciplina era anual, portanto, a média final refletia em duas temáticas bem diferentes: tecnologia e economia de transportes. A partir do ano de 2003 a disciplina passou a ser semestral, e 
portanto, a média final era representada apenas pela parte relacionada a economia de transportes. Mesmo assim, pode-se afirmar que, em 2004, o desempenho dos alunos certamente não piorou. Mesmo com o acréscimo de novos conteúdos no curso aos alunos, a atuação deles mostrou-se bastante satisfatória, o que parece indicar que o objetivo deste trabalho de pesquisa foi alcançado.

Estes resultados são um incentivo para docentes que querem se engajar neste ideal de melhorar a metodologia de ensino vigente na maioria das universidades, mas que por algum motivo ainda não mudaram seus métodos de ensino. Com esta avaliação pode-se afirmar que, neste caso, a inserção de alternativas pedagógicas em uma estratégia b-learning pode levar a uma melhoria no processo de ensino, inclusive de maneira quantitativa (comparação entre notas), como foi apresentado anteriormente.

\subsubsection{Análise feita através das provas}

Durante o decorrer do curso foram aplicados aos alunos duas provas, ambas com caráter teórico/prático (exercícios) e não puramente teórico. A primeira foi elaborada nos moldes dos métodos tradicionais de ensino e a segunda prova foi elaborada pelos próprios alunos, conforme descrito no item 6.2.2. A Tabela 8.8 mostra o desempenho dos alunos que faziam parte do "Grupo de Controle" e do "Grupo Experimental" com os dois estilos de elaboração das provas já descritos anteriormente.

Tabela 8.8: Avaliação comparativa dos tipos de provas e dos grupos (experimental e de controle) da turma de 2004

\begin{tabular}{lcccc}
\hline & \multicolumn{2}{c}{ Média das Provas } & \multicolumn{2}{c}{ Desvio Padrão } \\
\cline { 2 - 5 } & $\begin{array}{c}\text { Grupo de } \\
\text { Controle }\end{array}$ & $\begin{array}{c}\text { Grupo } \\
\text { Experimental }\end{array}$ & $\begin{array}{c}\text { Grupo de } \\
\text { Controle }\end{array}$ & $\begin{array}{c}\text { Grupo } \\
\text { Experimental }\end{array}$ \\
\hline Prova tradicional & 3,24 & 3,63 & 1,84 & 1,86 \\
\hline $\begin{array}{l}\text { Prova elaborada } \\
\text { pelos alunos }\end{array}$ & 8,09 & 8,52 & 1,40 & 0,96 \\
\hline
\end{tabular}

De acordo com a Tabela 8.8, pode-se observar que os alunos que faziam parte do "Grupo Experimental", ou seja, do grupo que além das atividades normais ainda foram levados a realizar pesquisa na Internet, tiveram um desempenho 
melhor (3,63 e 8,52) do que o "Grupo de Controle", ou seja, que não participou da experiência com a Internet $(3,24$ e 8,09), com relação aos dois tipos de elaboração das provas.

Cabe ressaltar que, mesmo quando se trata da avaliação tipo "prova", que por muitos é ainda vista com restrições, ela pode se tornar algo menos "temível". Para isto basta fazer com que os alunos participem da sua elaboração, como foi o caso deste trabalho. Além da participação ativa do aluno na etapa, ainda conseguiu-se um resultado quase três vezes melhor, em termos de nota (que espera-se reflita o conhecimento adquirido).

\subsubsection{Análise com as turmas de 2004}

Como foi citado anteriormente, os alunos dessa disciplina são sempre separados em duas turmas e, essa partição ocorreu de maneira diferente (40 / 20), para o ano de 2004. Com esta avaliação, pretende-se fazer uma comparação do desempenho das duas turmas, de acordo com as diferentes abordagens de ensino utilizadas nas salas de aula e ainda um desempenho entre a turma de quarenta alunos que foi desmembrada entre "Grupo de Controle" e "Grupo Experimental" (Tabela 8.9).

Tabela 8.9: Avaliação comparativa das turmas de 2004

\begin{tabular}{lccc}
\hline & $\begin{array}{c}\text { Número de } \\
\text { alunos }\end{array}$ & $\begin{array}{c}\text { Média das } \\
\text { notas finais }\end{array}$ & $\begin{array}{c}\text { Desvio } \\
\text { padrão }\end{array}$ \\
\hline Turma submetida à & $20 \mathrm{GC}$ & 5,82 & 1,10 \\
experiência & $20 \mathrm{GE}$ & 6,33 & 0,97 \\
\hline $\begin{array}{l}\text { Turma não submetida à } \\
\text { experiência }\end{array}$ & 20 & 5,29 & 2,06 \\
\hline
\end{tabular}

Com os resultados mostrados na Tabela 8.9 observa-se que novamente os alunos que fizeram parte do "Grupo Experimental" tiveram um desempenho superior ao dos demais, podendo-se inferir do potencial que a Internet propicia ao processo de aprendizagem. Além disso, pode-se observar que a turma submetida à experiência obteve um desempenho melhor do que a turma que foi submetida apenas à metodologia tradicional, o que sugere que o CD pode ter também contribuído para a melhoria do processo de ensino-aprendizagem. 
Com relação ao desvio padrão, pode-se observar que a distribuição das notas da turma que não foi submetida à experiência apresenta-se bem mais dispersa $(2,06)$, ou seja, o desvio padrão foi quase o dobro do que o da turma que foi submetida à experiência $(1,10$ e 0,97$)$. 


\section{CONSIDERAÇÕES FINAIS E SUGESTÕES PARA TRABALHOS FUTUROS}

Nas últimas décadas, devido ao grande desenvolvimento das redes de comunicação e de informação, o processo de globalização sofreu um grande impulso. Com isso, houve também a necessidade de redefinir o perfil e as tarefas dos profissionais, de maneira geral, e do engenheiro, em particular neste trabalho de tese, e redimensionar sua atuação perante a sociedade. Essa nova forma de atuação que começa a ser exigida, tanto pelo mercado de trabalho como pela sociedade, passa a influir nas potencialidades funcionais do engenheiro e por conseqüência, ser considerada no modelo educacional.

Diante disto, fundamentada nos conceitos do construtivismo de Piaget, onde o aluno deve ser responsável pela sua própria aprendizagem, aprendendo com isso a construir seu próprio conhecimento, esta pesquisa teve um objetivo bastante claro. Explorou e avaliou algumas alternativas para a melhoria do processo de ensino-aprendizagem de modo a preparar o futuro engenheiro a enfrentar o mercado de trabalho. Nesse sentido, deparou-se com o desafio de avaliar se os alunos seriam capazes de absorver novos tópicos sem comprometer o conteúdo programático tradicional, ou seja, sem ampliar o tempo dedicado à disciplina.

Para tanto, foram aplicadas numa disciplina específica que trata de planejamento de transportes, várias alternativas pedagógicas de modo a complementar o paradigma tradicional, permitindo ainda a inclusão de novos 
conteúdos. Vale ressaltar que as alternativas utilizadas, por serem técnicas utilizadas para o aprimoramento do processo de ensino-aprendizagem, podem ser aplicadas em qualquer disciplina, de qualquer curso. A seguir são feitas algumas considerações sobre cada alternativa/técnica utilizada nesta pesquisa.

A introdução dos conteúdos do curso num site da Internet (WebCT) permitiu observar, através dos resultados apresentados, um interesse significativo dos alunos em utilizar o site. Cerca de $80 \%$ dos alunos tiveram o primeiro acesso ao site em agosto e o último acesso em dezembro, período em que a disciplina foi oferecida. Além disso, $80 \%$ das páginas teve grande número de visitas, confirmando o interesse pelo uso da ferramenta. Pode-se concluir com esses dados, que mesmo que de maneira tênue, o WebCT ajudou a modificar e aprimorar o processo de ensino-aprendizagem.

Um dos grandes desafios deste trabalho e que exigiu uma boa parte do tempo consumido pela autora no mesmo, foi a elaboração de conteúdos para serem disponibilizados aos alunos através de CD. Além do esforço demandado para aquisição dos conhecimentos necessários para o desenvolvimento da parte técnica, foi preciso conceber cada página de modo a atingir, senão todos, diversos tipos de estudantes (Modelo de Kolb) e estilos de aprendizagem (Modelo de Felder e Silverman), de modo a contribuir para um ensino mais dinâmico e atrativo. Pôde-se concluir, com esta etapa, que com a construção dos módulos da disciplina utilizando diferentes mídias, criatividade e baseandose nos modelos de aprendizagem apresentados, foi possível atingir todos os tipos de alunos e estilos de aprendizagem.

$\mathrm{Na}$ análise feita sobre as preferências de aprendizagem dos alunos, observa-se que $57 \%$ deles declararam preferir uma aprendizagem balanceada entre o que é dado em sala de aula (método tradicional) e alguns recursos inovadores, como foi o caso do conteúdo apresentado no CD. Estes resultados, mostrando boa aceitação por parte dos alunos, confirmaram a necessidade de se aplicar as metodologias chamadas b-learning, combinando assim os métodos tradicionais e inovadores de ensino. Isto reafirma a questão de que o caminho é o de complementar a metodologia já existente e não substituí-la. Esse 
processo de transição, no entanto, deve ser gradual e constante, para que possa ser bem aceito pelos alunos e professores.

Outra alternativa pedagógica utilizada na disciplina e que trouxe resultados positivos para o processo de ensino-aprendizagem foi o Trabalho em Grupo. Esta técnica foi utilizada em dois momentos durante o curso. Primeiro para a elaboração de seminários e mais tarde na etapa de preparação e avaliação das provas. Nos dois momentos, a turma foi dividida em oito grupos. Esta técnica possibilitou o enriquecimento de experiências e vivências por parte dos alunos.

A junção das técnicas de Trabalho em Grupo e Seminários trouxe benefícios visíveis aos alunos. Além da troca de idéias proporcionadas pelo estudo em grupo, os seminários foram elaborados sobre assuntos não vistos em sala de aula. Isto significa que os alunos estavam inserindo novos conteúdos na disciplina, sem que fosse necessário alterar a grade curricular. Esta etapa foi avaliada através do Modelo de Classificação da Taxonomia de Bloom, onde se pôde concluir que mesmo sendo uma atividade muito subjetiva para se avaliar (15 minutos de apresentação), a maioria dos grupos atingiu até o nível quatro da classificação de Bloom. Este é um nível bastante satisfatório para ter sido alcançado diante dos assuntos inovadores estudados, mostrando também, resultados bastante positivos.

As atividades realizadas com o auxílio da Internet motivaram os alunos pelas inúmeras possibilidades de pesquisa, estimulando a curiosidade, o raciocínio lógico, a autonomia e o senso de responsabilidade, dentre outras coisas. Cabe ressaltar, que tudo isso foi possível sem alterar a grade curricular do curso, que se constituiu no desafio maior dessa pesquisa.

Ao se fazer a comparação do desempenho dos alunos que cursaram a mesma disciplina aqui em questão "Planejamento e Análise de Sistemas de Transportes" com os mesmos professores, no decorrer dos dez últimos anos, observou-se um aumento na média das notas de $11 \%$ nesta turma de 2004 (turma onde foram feitas as mudanças na metodologia de ensino). 
Em diversos momentos pôde-se perceber que o "Grupo Experimental", grupo de alunos que, além de suas atividades normais durante o curso, era constantemente convidado a realizar pesquisas e a explorar a Internet para a busca de novas informações e conhecimentos, sempre que comparado com o outro grupo ("Grupo de Controle"), obteve um desempenho superior em suas atividades. Esse fato reafirma a importância de estimular o aluno a buscar seu conhecimento, colocando-o numa posição ativa dentro da sala de aula, que irá refletir no processo de ensino-aprendizagem, visto que o retorno parece certo e positivo, a julgar pelo que foi observado nesta pesquisa.

Os resultados apresentados indicam que as alternativas pedagógicas consideradas, de certa forma contribuíram para o aprimoramento da metodologia tradicional de ensino, apresentando resultados positivos para o aprendizado, mesmo dentro de uma grade curricular rígida. O que sustenta a hipótese de que ao mesmo tempo em que fazem parte do problema, as novas tecnologias podem fornecer os recursos necessários para a solução.

Assim, pode-se dizer que a contribuição deste trabalho para o ensino de Engenharia de Transportes foi significativa e satisfatória, visto que, dentre outras coisas, em nível nacional, poucos são os trabalhos nesta área e com essa preocupação.

Conclui-se ainda que é possível aprimorar o processo de ensinoaprendizagem, através da renovação dos conceitos de educação e de métodos e técnicas utilizados para aprimorar a comunicação de conceitos e conteúdos para os alunos, mesmo diante de uma grade curricular rígida. Basta apenas e antes de mais nada, que sejam rompidas as barreiras existentes dentro do próprio docente ou educador.

Como trabalhos futuros, propõe-se explorar de forma mais intensa os "Learning Management Systems" (LMS), visto ser uma ferramenta muito utilizada para se aprimorar o processo de ensino-aprendizagem agora e para um futuro já muito próximo. Por fim, como o material complementar oferecido aos alunos em CDROM não foi elaborado e desenvolvido por um Web Designer, seria 
interessante desenvolver e aprofundar pesquisas que visassem tornar este tipo de mídia e recursos inovadores mais agradáveis aos alunos, considerando aspectos estéticos como cor, tipo e tamanho das letras, recursos gráficos, etc. 


\section{REFERÊNCIAS BIBLIOGRÁFICAS}

ABREU, M.C.; MASETTO, M.T. (1990). O professor universitário em aula: prática e princípios teóricos. 130p. Ed. Associados, São Paulo.

ALMEIDA, P.N. (1973). O ensino globalizante em dinâmica de grupo. São Paulo, Saraiva.

ALMEIDA, A.J.M (2002). O professor e a valorização de sua atividade docente. In: Feltran. Santis, R.C. (org.). Avaliação na educação superior. Ed. Papirus, 190p. São Paulo.

ANDRADE, M.C.; GOMES, M.C. (1998). Workshop: recursos educativos na Internet. Disponível em: <http://www.ipv.pt/millenium/17_est6.htm. Acesso em: 10 de maio de 2003.

ANDRÉ, M.E.D.A; PASSOS, L.F. (2001). Avaliação escolar: desafios e perspectivas. In Castro, A.D. e Carvalho, A.M.P. (orgs). Ensinar a ensinar. Didática para a escola fundamental e média. São Paulo, Ed. Pioneira, p. 177-195.

ASSAYAG, E.S. (1996). Internet na graduação em engenharia na FTUA. In: Congresso Brasileiro de Ensino de Engenharia, XXIV Cobenge, Manaus, AM.

BARBUZZA, R.; CASTRO, M. (1998). Sistema multimedia de la Universidad Nacional del Centro de la Provincia de Buenos Aires. In: Congreso Internacional y Exposición de Informática e Internet, Mendoza, CD-ROM.

BARROS, C.S.G. (1996). Psicologia e construtivismo. Série Educação. Ed. Atira, São Paulo.

BELHOT, R.V. (1997). Estratégias de ensino e de aprendizagem. In: Congresso Brasileiro de Ensino de Engenharia, XXV Cobenge, v. 4, Salvador, BA.

BELHOT, R.V.; FIGUEIREDO, R.S.; MALAVÉ, C.O. (2001). O uso da simulação no ensino de engenharia. In: Congresso Brasileiro de Ensino de Engenharia, XXIX Cobenge, p. 445451.

BELTRÃO, P.A.; SCHIEFLER, F.M.F. (1995). Atualização curricular no curso de engenharia industrial mecânica do CEFET, PR. In: Congresso Brasileiro de Ensino de Engenharia, XXIII Cobenge, p. 813-829.

BLOOM, B.S. (1956) Taxonomy of educational objectives: The classification of educational goals: Handbook l, cognitive domain. New York ; Toronto: Longmans, Green.

BOARETTO JR., H. (1996). Ensino apoiado por computador aplicado a ferramentas gráficas gerenciais. 159 p. Dissertação (Mestrado). Escola de Engenharia de São Carlos, Universidade de São Paulo. 
BORGES, M.N; VASCONCELOS, F.H. (1997). Novos princípios e conceitos do projeto curricular para cursos de graduação em engenharia. In: Revista de Ensino de Engenharia, n. 17, p. $19-26$.

BRINGHENTI, I. (1992). Fundamentos para o ensino de engenharia civil. Tese (Doutorado). Escola Politécnica da Universidade de São Paulo, São Paulo.

BROOKFIELD, S.D. (1995). Becoming a critically reflective teacher. San Francisco.

CANEN, A.; GRANT, n. (2001) Conhecimento e multiculturalismo em políticas educacionais no mercosul: limites e possibilidades. In: Canen, A. e Moreira, A.F.B. (orgs.). Ênfases e Omissões no currículo. Ed. Papirus, Campinas.

CARVALHO, A.A.A. (1998) Os documentos hipermídia estruturados segundo a teoria da flexibilidade cognitiva: importância dos comentários temáticos e das travessias temáticas na transferência do conhecimento para novas situações. Tese (Doutorado). Instituto de Educação e Psicologia. Universidade do Minho, Portugal.

CHRISTIE, M.F.; JAUN, A.; JONSON, L. (2002). Evaluating the use of information and comunication technologies in engineering education. European Journal of Engineering Education, v. 27, n. 1, p. 13-20.

COLENCI, A.T.; BELHOT, R.V.; COLENCI JR. A. (1998). O ensino de engenharia como uma atividade de serviços. In: Anais do XXVI Congresso Brasileiro de Ensino de Engenharia. São Paulo. (CD-ROM).

COLENCI, A.T. (2000). O ensino de engenharia como uma atividade de serviços: a exigência de atuação em novos patamares de qualidade acadêmica. Dissertação (Mestrado). Escola de Engenharia de São Carlos.

COOK, T.D.; REICHARDT, C.S. (1979). Qualitative and quantitative methods in evaluation research. Ed. Sarge, Beverly Hills.

CORREIA, A.M.A.; CHENG, L. (2000). Aprender a ensinar a aprender. In: Congresso Brasileiro de Ensino de Engenharia, XXVIII Cobenge, Ouro Preto, MG.

CORREIA, A.M.A.; CHENG, L. (2001). Estudantes e professores de perfil. In: Congresso Brasileiro de Ensino de Engenharia, XXIX Cobenge, p.197-205.

DANTAS, S.H.G. (1993). Ensino ou educação em engenharia: a formação didático-pedagógica dos engenheiros-professores. In: Revista de Ensino de Engenharia, v. 10, n. 3, p. 24-29.

DA NOVA, F.(2003). Metodologia pedagógica do LED à frente das tendências. Disponível em: $<$ http:www.troll.led.ufsc.br:18080/portal/revista_materiais.jsp?id_secao=18id_materia=2658 $>$ Acesso em 21 de maio de 2003.

DRUCKER, P.F. (1968). Uma era de descontinuidade: orientação para uma sociedade em mudança. São Paulo. Círculo do Livro.

EIDSON, W.C.; BULLOCK, D.M. (2001). Emerging education opportunities in civil infrastructure. In: Transportation Research Board. CD-ROM.

FELDER, R.M.; SILVERMAN, L.K. (1988). Learning and Teaching Styles in Engineering Education. Engineering Education, vol. 78, n.7, April, p. 674-681.

FELDER, R.M.; FELDER, G.N.; DIETZ, E.J. (1998). A longitudinal study of engineering student 
performance and retention, comparisons with traditionally-taught students. Journal of Engineering Education, v.87, n.4, p.469-480.

FELDER,R.M.; SOLOMAN, B.A. Index of Learning Styles (ILS). Disponível em: $<w w w 2 . n c s u . e d u / u n i t y / l o c k e r s / u s e r s / f / f e l d e r / p u b l i c / l L S p a g e . h t m l>$. Acessado em maio de 2004.

FERREIRA, P.M. (2004). O que dizem os peritos em e-learning. Diário econômico, 28 de julho, p.7, Portugal. Disponível em:

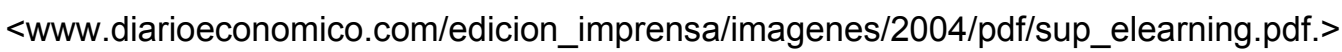
Acesso em dezembro de 2004.

FERREIRA, M.A.G.V. (1999). O ensino de engenharia, os novos paradigmas de aprendizagem e a Internet. In: Congresso Brasileiro de Ensino de Engenharia, XXVII Cobenge, Natal, RN.

FIGUEIRA, M. (2003). Construir uma infra-estrutura para o e-learning. Disponível em: $<w w w$.aprendernanet.com/artigos.asp?x1=62236752>. Acesso em março de 2005.

FRASER, B.J.; WALBERG, H.J. (1991) Educational environments - evaluation, antecedents and consequences. 305p. Ed. Pergamon Press, Oxford.

FREIRE, M.E.P. (1998). O Sistema tutor de um ambiente inteligente para treinamento e ensino. Dissertação (Mestrado). Instituto de Ciências Matemáticas de São Carlos, Universidade de São Paulo.

FRANCO, L.R.H.R.; BRAGA, D.B. (2004). Revolucionando as técnicas de aprendizagem da engenharia com o EAD. In: World Congress on Engineering and Technology Education, p.1083-1087, São Paulo, Brasil.

FREITAS, R.L.A. (2001). As novas tecnologias e o novo paradigma da educação: fundamentação e a produção da Escola do Futuro da USP. 228p. Dissertação (Mestrado). Universidade Politécnica de São Paulo, São Paulo.

GASPARETO, C.A.; DANNA, F.L.; IIDA, I.; NASCIMENTO, O.V.; VIEIRA, R.C.C. (1990). Perfil do engenheiro do século XXI. In: Congresso Brasileiro de Ensino de Engenharia, Abenge, v. 1, p. 135-146.

GONZALEZ, L.A.G.; LEMOS, F.; RUGGIERO, W. (1999). Methodology for the organization and preparation of distance learning courses. In: International Conference on Technology and Distance Education. Building Bridges Through Tecnology and Distance Education. Fort Laurderdale, Florida.

GONZALEZ, L.A.G. (2000). Educação pela web: metodologia e ferramenta de elaboração de cursos com navegação dinâmica. Dissertação (Mestrado). Escola Politécnica da Universidade de São Paulo.

GUERRA, J.H.L. (2000). Utilização do computador no processo de ensino-aprendizagem: uma aplicação em planejamento e controle da produção. Dissertação (Mestrado). Escola de Engenharia de São Carlos, Universidade de São Paulo.

HARB, J.N.; TERRY, R.E.; HURT, P.K; WILLIAMSON, K.J. (1992). Teaching through the cycle: application of learning style theory to engineering education at Brigham Young University. 
Disponível em:

<http://www.minerva.uevora.pt/simpósio/comunicações/98paper_simp_edu.html.> Acesso em: 5 de junho de 2001.

HARB, J.N.; DURRANT, S.O. e TERRY, R.E. (1993). Use of the Kolb learning cycle and the 4MAT system in engineering education. Journal of Engineering Education, vol. 28, n. 2, p. 70-77.

HERDER, P.M.; SUBRAHMANIAN, E.; TALUKDAR, S.; TURK, A.L.; WESTEBERG, A.W. (2002). The use of video-taped lectures and web based communications in teaching: a distanceteaching and cross-Atlantic collaboration experiment. European Journal of Engineering Education, v. 27, n. 1, p. 39-48.

HUTCHINS, H.M. (2001). Enhancing the business communication course through WebCT. Business Communication Quarterly. New York.

KEEGAN, D.; DIAS, A.; BATISTA, C.; OLSEN, G.A.; FRITSCH, H.; FOLLMER, H.; MICENCOVÁ, M.; PAULSEN, M.F.; DIAS, P.; PIMENTA, P. (2002). O papel dos sistemas de gestão da aprendizagem na Europa. Lisboa, Portugal, p.277.

KOLB, D.A. (1984). Experimental learning: experience as a source of learning and development, Prentice-Hall, New Jersey.

KOVALINKA, P. (2003). E-Learning for structural mechanics. In: Encuentro Internacional de Enseñanza de la Ingeniería Civil. Ciudad Real. ACTAS DEL I ENCUENTRO INTERNACIONAL DE ENSEÑANZA DE LA INGENIERÍA CIVIL.

KURI, N.P.; GIORGETTI, M.F. (1996). Índice de Estilos de Aprendizagem (Index of Learning Styles). Escola de Engenharia de São Carlos, Universidade de São Paulo.

KURI, N.P. (1998). Kolb's learning cycle: an alternative strategy for engineering education. In: ICEE 98 - International Conference on Engineering Education, Rio de Janeiro, RJ.

KURI, N.P.; GIORGETTI, M.F. (1998). Planejamento de ensino-aprendizagem. Apostila desenvolvida para a disciplina de Metodologia de Ensino do Departamento de Hidráulica da Escola de Engenharia de São Carlos.

KURI, N.P. (2000). Kolb's Learning Cycle: an alternative strategy for engineering education. In: ERIC/CSMEE, ED 441666, November.

KURI, N.P. (2004) Tipos de personalidade e estilos de aprendizagem: proposições para o ensino de engenharia. Tese (Doutorado). Universidade Federal de São Carlos, Centro de Ciências Exatas e Tecnologia.

LEÃO, F. (1995). Pronunciamento: que perfil deverão ter os engenheiros do futuro? Revista de Ensino de Engenharia, n. 14, p. 7-10.

LEVY, P. (1999). La universidad em la sociedad de la información. In: Documentos Columbus sobre gestion universitaria, Conferencia São Paulo - Brasil, 23-25 de octubre de 1996, Centro de Documentación e Información, Sector de la Educación, UNESCO.

LIMA, R.V. (1996). A utilização de sistemas multimídia na educação e treinamento: uma aplicação MRPII. Dissertação (Mestrado). Escola de Engenharia de São Carlos, Universidade de São Paulo. 
LIMA, R.V. (2002). Cenário de integração do processo de desenvolvimento de produtos: uma proposta de ensino e treinamento baseada em tecnologia de educação. Tese (Doutorado). Escola de Engenharia de São Carlos, Universidade de São Paulo.

LINSINGEN, I. von; PEREIRA, L.T.V.; CABRAL, C.G.; BAZZO, W.A. (1999) (org.). Formação do engenheiro: desafios da atuação docente, tendências curriculares e questões contemporâneas da educação tecnológica. Ed. UFSC, Florianópolis.

LIU, X.; FANG, D. (2002). Predicaments and expectations of civil engineering education in China. European Journal of Engineering Education, v. 27, n. 2, p. 219-224.

MACHADO, J. (2001). E-learning em Portugal. FCA. Editora de Informática, Lisboa.

MARCELO, C. (1998). Pesquisa sobre a formação de professores - O conhecimento sobre aprender a ensinar. In: Revista Brasileira de Educação, n. 9, p. 51-75.

MARCHIONNI, G. (1990). Evaluating Hypermedia-Based Learning. In: D.H. Jonassen e H. Mandl (ed.), Designing Hypermedia for Learning. Berlin, Springer-Verlag. p.355-373.

MARTINS FILHO, P.D. (1997). Introduzindo novas tecnologias educacionais na formação da engenharia. In: Congresso Brasileiro de Ensino de Engenharia, Abenge, 25, v. 9, p. 19121924.

MASETTO, M.T. (1992). Aulas vivas. São Paulo, MG Associados, p.79.

MATTA, A.W.R. (2002). Ensino-aprendizagem a distância: considerações epistemológicas e o processo cognitivo. In: IX Congresso Internacional de Educação a Distância. ABED Associação Brasileira de Educação a Distância.

MELLO, J.C.B.S; LINS, M.P.E.; MELLO, M.H.S.; GOMES, E.G. (2002). Evaluating the performance of calculus classes using operational research tools. European Journal of Engineering Education, v. 27, n. 2, p. 209-218.

MIZUKAMI, M.G.N. (2002). Formadores de professores, conhecimentos da docência e casos de ensino. In: Reali, A.M.M.R. \& Mizukami, M.G.N. Formação de professores: práticas pedagógicas e escola. UFSCAR, INEP, COMPED.

NAEGELI, C.H.; ANTONINI, R.C.; ELLWANGER, G.B. (1997). Desenvolvimento de material didático para ensino de engenharia: multimídia sobre resistência dos materiais e comportamento das estruturas. In: Congresso Brasileiro de Ensino de Engenharia, Abenge, v. 3, p. 1267-1282.

NAKAO, O.S. (2000). Aperfeiçoamento didático de um curso de mecânica das estruturas. Dissertação (Mestrado). Escola Politécnica da Universidade de São Paulo.

NITZKE, J.A. (1998). Fermentando Piaget - Como fazer pão. Disponível em: <http://www.relfinal.htm\#2>. Acesso em: 10 de maio de 2003.

NIXON, W.A. (2000). Development of a graduate course in winter highway maintenance. In: Transportation Research Board. CD-ROM.

PALLOF, R.M.; PRATT, K. (2002). Building learning communities in cyberspace: effective strategies for the online classroom. Tradução de Vinícius Figueira, 248p.

PEREIRA, M. A., BOCANEGRA, C.W.R, CARDENAS, C. B. B., SILVA, A.N.R. (2003). La importância del conocimiento y uso de nuevas técnicas en Ingeniería Civil: una aplicación 
práctica con Redes Neuronales Artificiales In: Encuentro Internacional de Enseñanza de la Ingeniería Civil. Ciudad Real. ACTAS DEL I ENCUENTRO INTERNACIONAL DE ENSEÑANZA DE LA INGENIERÍA CIVIL.

PEREIRA, A. (2004). Learning Management Systems. Disponível em: <http:www.nesi.com.pt/nesi/files/monitor23.pdf>. Acesso em: 23 de março de 2005.

PEREIRA, M.A.; KURI, N.P.; SILVA, A.N.R. (2004). Os estilos de aprendizagem e o ensino de engenharia de transportes. In: XVIII Congresso de Pesquisa e Ensino em Transportes ANPET, p.1529-1540, Rio de Janeiro.

PEREIRA, M.A.; KURI, N.P.; SILVA, A.N.R. (2005). Modelos de estilos de aprendizagem auxiliando no planejamento de recursos multimídia para o ensino de engenharia de transportes. In: World Congress on Engineering and Technology Education. Trabalho aceito para apresentação. Bertioga, Brasil.

PEREIRA, L.T.V.; BAZZO, W.A. (1997). Ensino de engenharia na busca do seu aprimoramento. Florianópolis: Edufsc.

PÉREZ GOMEZ, A. (1992). O pensamento prático do professor - a formação do professor como prático reflexivo. In: Nóvoa, A. (org.). Os professores e sua formação. Publicações Dom Quixote, Lisboa, p. 51-76.

PERRENOUD, P. (1995). As novas didáticas e as novas estratégias dos alunos face ao trabalho escolar. In: Perrenoud, P. Ofício de aluno e sentido do trabalho escolar. Porto Ed. p. 115-134.

RIBAS, P.A.V.; SILVA FILHO, J.F.; COMIOTTO, M.S. (1998). A new paradigm in engineering education in PUC-RS. In: ICEE 98 - International Conference on Engineering Education, Rio de Janeiro, RJ.

RIBEIRO, L.R.C. (2000). Programas da qualidade total e educação: reflexões sobre a utilização de seus princípios no ensino de engenharia. Dissertação (Mestrado). Escola de Engenharia de São Carlos, Universidade de São Paulo.

RODRIGUEZ, J.M.; GONZÁLEZ, V.; GONZÁLEZ, J.E.; RUEDA, C.; DE HARO, L.; MARTÍNPASCUAL, C. (2001). Development of education software for the teaching of telecomunication engineering by using Matlab. European Journal of Engineering Education, v. 26, n. 4, p. 361-374.

ROSENBERG, M.J. (2002). E-learning: strategies for delivering knowledge in the digital age. New York, McGraw-Hill.

RUIZ, C.C.P. (1994). A mecânica clássica e as disciplinas essenciais ao curso de engenharia mecânica. In: Congresso Brasileiro de Ensino de Engenharia, Abenge, p. 158-164.

SANTOS, A. (2001). Ensino a distância e tecnologias de informação e-learning. FCA Editora de Informática, Lisboa.

SALUM, M.J.G.; GUIMARÃES, H.A. (1996). A Diversificação na formação do engenheiro Uma realidade ou necessidade? In: Congresso Brasileiro de Ensino de Engenharia - XXIV Cobenge, Manaus, AM. 
SHARP, J.E. (2001). Teaching teamwork communication with Kolb learning style inventory. In: ASEE/IEEE Frontiers in Educational Conference, Reno, N.V. Disponível em <http://fie.engrng.pitt.edu>. Acessado em 01 de dezembro de 2004.

SILVA, P.A.L. (1997). O mercado global do século XXI e o profissional de engenharia. In: Congresso Brasileiro de Ensino de Engenharia, XXV Cobenge, v. 2, p. 983-994, Salvador, BA.

SILVA, C.R.O. (1998). Bases pedagógicas e ergonômicas para concepção e avaliação de produtos educacionais informatizados. Dissertação. (Mestrado). Departamento de Engenharia de Produção da Universidade Federal de Santa Catarina.

SMITH, C.; MAYES, T. (1996). Telematics applications for educational and training: usability guide comission of the European Communities, ICBL.

SMITH, K.A. (2001). Cooperative learning and the new paradigm for engineering education.

Disponível em:

<http://129.25.62.195/professional_development/files/karl\%20Smith\%20workshop.pdf> Acesso em 10 de abril de 2003.

SORIANO, H.L.; DIAZ, B.E.; LIMA, S.S. (1992). Enfoque moderno no ensino de análise de estruturas. In: Congresso Brasileiro de Ensino de Engenharia, Abenge, p. 561-568.

STICE, J.E. (1987). Using Kolb's Learning Cycle to Improve Student Learning. Engineering Education, p.291-296.

SOUZA, L.S.H. (2001). O uso da Internet como ferramenta de apoio ao processo de ensinoaprendizagem da engenharia de transportes. Dissertação (Mestrado). Escola de Engenharia de São Carlos, Universidade de São Paulo.

TARAMAN, S.R. (2004). An innovative e-learning approach for engineering education. In: WCETE'2004 - World Congress on Engineering and Technology Education, CD-ROM, São Paulo.

TAVARES, C.G. \& BELHOT, R.V. (1998). Uso da tecnologia no processo de ensino. In: Simpósio de Iniciação Científica da USP, v. 2, 321p. São Paulo.

TAJRA, S.F. (2001). Informática na educação: novas ferramentas pedagógicas para o professor da atualidade, $3^{\mathrm{a}}$ Edição, Ed.Érica, São Paulo.

TOBAR, C.M. e FREITAS, R.L. (2004). Using learning styles in student modeling. In: World Congress on Engineering and Technology Education, CD-ROM, São Paulo, Brasil.

ZEICHNER, K. (1993). A formação reflexiva de professores: Idéias e práticas. Ed. Educa, Lisboa.

ZYWNO, M.S. e WAALEN, J.K. (2001). The effect of hypermedia instruction on achievement and attitudes of students with different learning styles. In: ASSE Anual Conference and Exposition, Albuquerque, New Mexico.

ZYWNO, M.S. (2003). Student learning styles, web use patterns and attitudes toward hypermedia - enhanced instruction. Proceedings of the $33^{\text {rd }}$ ASSE/IEE Frontiers in Education Conference, Session S1D, Boulder, CO. 


\section{ANEXOS}

ANEXO A - EXEMPLO DE UMA PROVA ELABORADA PELOS ALUNOS ANEXO B - PLANILHA DE AVALIAÇÃO DOS SEMINÁRIOS 


\title{
ANEXO A - EXEMPLO DE UMA PROVA ELABORADA PELOS ALUNOS
}

\author{
Planejamento e Análise de Sistemas de Transportes \\ STT405 \\ PROVA 02 \\ $15 / 12 / 04$
}

\section{A5F3}

1. A velocidade média numa via hipotética de uma via de direção única com uma faixa de tráfego é de 49,5 milhas $/ \mathrm{h}(80 \mathrm{~km} / \mathrm{h})$. O tráfego é composto por $79 \%$ de automóveis, $5 \%$ de caminhões médios e $16 \%$ de caminhões pesados. O fluxo horário de projeto é de 1100 veíc/h. Pede-se determinar os trechos que sofrem influência de aceleração e de desaceleração, e as respectivas velocidades equivalentes.

\section{Avaliação da questão}

1) A questão é coerente, ou seja, o enunciado e os dados fornecidos permitem a sua resolução.

( ) Concordo plenamente

( ) Concordo parcialmente

( ) Não sei

( ) Discordo parcialmente

4

( ) Discordo totalmente

3) A questão é concisa, sem perder a clareza, não permitindo interpretações ambíguas.

( ) Concordo plenamente

( ) Concordo parcialmente

( ) Não sei

( ) Discordo parcialmente

( ) Discordo totalmente
2) A questão é criativa e contribui para a consolidação do conhecimento adquirido no curso.
( ) Concordo plenamente
( ) Concordo parcialmente
( ) Não sei
( ) Discordo parcialmente
( ) Discordo totalmente

4) A questão exige um domínio do conteúdo teórico oferecido no curso.
( ) Concordo plenamente
( ) Concordo parcialmente
( ) Não sei
( ) Discordo parcialmente
( ) Discordo totalmente 
5) A questão pode ser resolvida no tempo proposto
( ) Concordo plenamente
( ) Concordo parcialmente
( ) Não sei
( ) Discordo parcialmente
( ) Discordo totalmente

2. O método das árvores, é uma técnica utilizada para a determinação do caminho mínimo em uma malha viária. O desenho seguinte representa parte da malha viária do estado de São Paulo, onde temos as cidades e pontos de intersecções entre vias representadas por nós e as vias representadas por arcos. Em cada arco é apresentado os respectivos tempos médios (em minutos) de viagem. Com base nesses dados, pede-se:

a) Desenhe uma tabela de par origem - destino com os respectivos tempos de viagem, entre São Carlos (1) e as demais cidades apresentadas;

b) Este método é totalmente seguro? Por que?

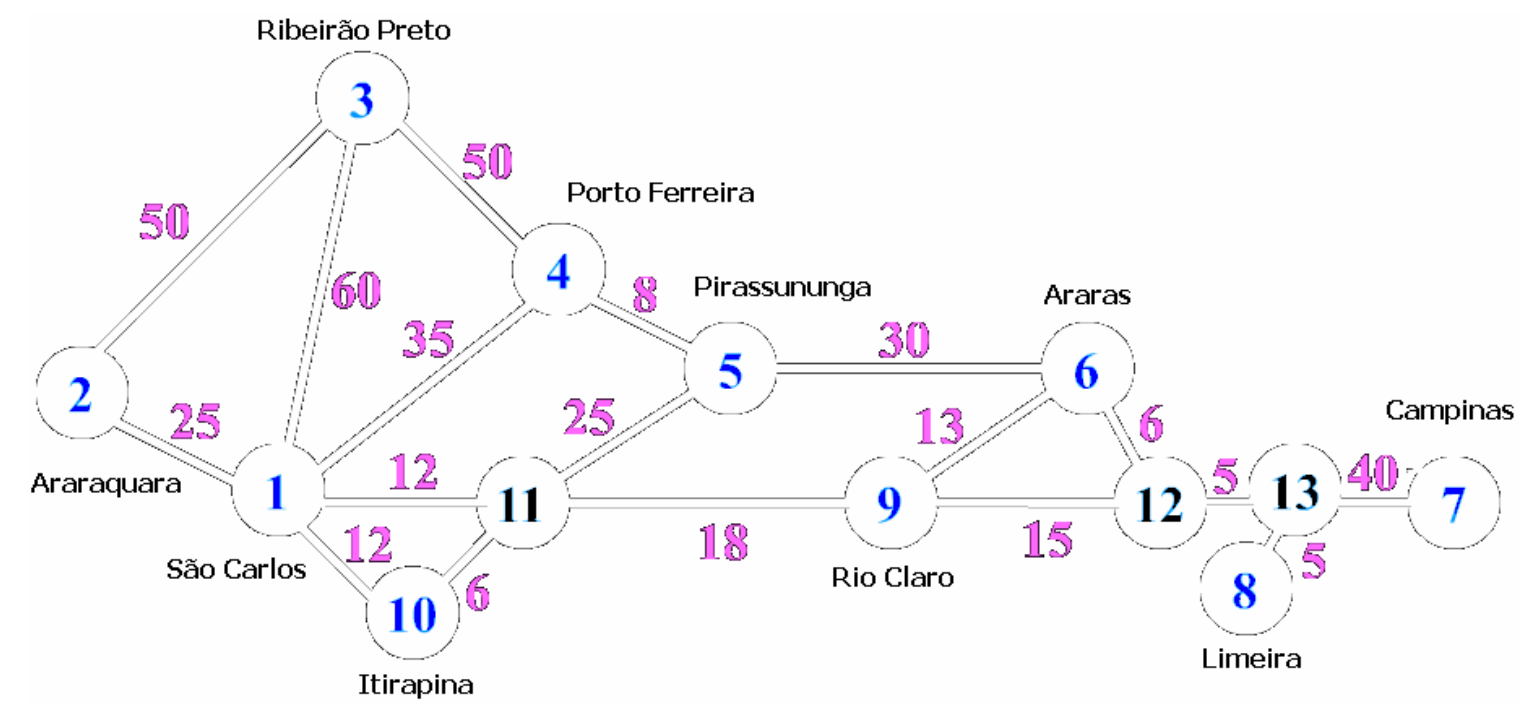

\section{Avaliação da questão}

1) A questão é coerente, ou seja, o enunciado e os dados fornecidos permitem a sua resolução.

( ) Concordo plenamente

( ) Concordo parcialmente

( ) Não sei

( ) Discordo parcialmente

( ) Discordo totalmente

2) A questão é criativa e contribui para a consolidação do conhecimento adquirido no curso.
( ) Concordo plenamente
( ) Concordo parcialmente
( ) Não sei
( ) Discordo parcialmente
( ) Discordo totalmente 
3) A questão é concisa, sem perder a clareza, não permitindo interpretações ambíguas.

( ) Concordo plenamente

( ) Concordo parcialmente

( ) Não sei

( ) Discordo parcialmente

( ) Discordo totalmente

5) A questão pode ser resolvida no tempo proposto

( ) Concordo plenamente

( ) Concordo parcialmente

) Não sei

( ) Discordo parcialmente

( ) Discordo totalmente
4) A questão exige um domínio do conteúdo teórico oferecido no curso.

( ) Concordo plenamente

( ) Concordo parcialmente

( ) Não sei

( ) Discordo parcialmente

( ) Discordo totalmente 


\section{ANEXO B - PLANILHA DE AVALIAÇÃO DOS SEMINÁRIOS}

\section{STT405 Planejamento e Análise de Sistemas de Transporte Dezembro/2004}

Avaliação do projeto de curso

$\mathrm{N}^{\circ}$

Nome:

USP

\section{ESCALA DE ATITUDES EM RELAÇÃO AOS SEMINÁRIOS}

Os conteúdos foram ministrados de forma clara.

\begin{tabular}{|c|c|c|c|c|c|c|c|}
\hline $\begin{array}{c}\text { Redes Neur. } \\
\text { Art. }\end{array}$ & Lógica Fuzzy & Alg. Genéticos & Sist. Inf. Geog. & Aval. Multicrit. & $\begin{array}{l}\text { Autôm. } \\
\text { Celular }\end{array}$ & $\begin{array}{c}\text { Sim. } \\
\text { Annealing }\end{array}$ & Est. Espacial \\
\hline $\begin{array}{l}\text { ( ) Concordo } \\
\text { Totalmente }\end{array}$ & $\begin{array}{l}\text { ( ) Concordo } \\
\text { Totalmente }\end{array}$ & $\begin{array}{l}\text { ( ) Concordo } \\
\text { Totalmente }\end{array}$ & $\begin{array}{l}\text { ( ) Concordo } \\
\text { Totalmente }\end{array}$ & $\begin{array}{l}\text { ( ) Concordo } \\
\text { Totalmente }\end{array}$ & $\begin{array}{l}\text { ( ) Concordo } \\
\text { Totalmente }\end{array}$ & $\begin{array}{l}\text { ( ) Concordo } \\
\text { Totalmente }\end{array}$ & $\begin{array}{l}\text { ( ) Concordo } \\
\text { Totalmente }\end{array}$ \\
\hline ( ) Discordo & ( ) Discordo & ( ) Discordo & ( ) Discordo & ( ) Discordo & ( ) Discordo & ( ) Discordo & ( ) Discordo \\
\hline ( ) Não sei & ( ) Não sei & ( ) Não sei & ( ) Não sei & ( ) Não sei & ( ) Não sei & Não sei & ( ) Não sei \\
\hline ( ) Concordo & ( ) Concordo & ( ) Concordo & ( ) Concordo & ( ) Concordo & ( ) Concordo & ( ) Concordo & ( ) Concordo \\
\hline $\begin{array}{l}\text { ( ) Discordo } \\
\text { Totalmente }\end{array}$ & $\begin{array}{l}\text { ( ) Discordo } \\
\text { Totalmente }\end{array}$ & $\begin{array}{l}\text { ( ) Discordo } \\
\text { Totalmente }\end{array}$ & $\begin{array}{l}\text { ( ) Discordo } \\
\text { Totalmente }\end{array}$ & $\begin{array}{l}\text { ( ) Discordo } \\
\text { Totalmente }\end{array}$ & $\begin{array}{l}\text { ( ) Discordo } \\
\text { Totalmente }\end{array}$ & $\begin{array}{l}\text { ( ) Discordo } \\
\text { Totalmente }\end{array}$ & $\begin{array}{l}\text { ( ) Discordo } \\
\text { Totalmente }\end{array}$ \\
\hline
\end{tabular}

Houve coerência dos diferentes tópicos do seminário entre si e em relação ao conteúdo do curso.

\begin{tabular}{|c|c|c|c|c|c|c|c|}
\hline $\begin{array}{c}\text { Redes Neur. } \\
\text { Art. }\end{array}$ & Lógica Fuzzy & Alg. Genéticos & Sist. Inf. Geog. & Aval. Multicrit. & $\begin{array}{l}\text { Autôm. } \\
\text { Celular }\end{array}$ & $\begin{array}{c}\text { Sim. } \\
\text { Annealing }\end{array}$ & Est. Espacial \\
\hline $\begin{array}{l}\text { ( ) Concordo } \\
\text { Totalmente }\end{array}$ & $\begin{array}{l}\text { ( ) Concordo } \\
\text { Totalmente }\end{array}$ & $\begin{array}{l}\text { ( ) Concordo } \\
\text { Totalmente }\end{array}$ & $\begin{array}{l}\text { ( ) Concordo } \\
\text { Totalmente }\end{array}$ & $\begin{array}{l}\text { ( ) Concordo } \\
\text { Totalmente }\end{array}$ & $\begin{array}{l}\text { ( ) Concordo } \\
\text { Totalmente }\end{array}$ & $\begin{array}{l}\text { ( ) Concordo } \\
\text { Totalmente }\end{array}$ & $\begin{array}{l}\text { ( ) Concordo } \\
\text { Totalmente }\end{array}$ \\
\hline ( ) Discordo & ( ) Discordo & ( ) Discordo & ( ) Discordo & ( ) Discordo & ( ) Discordo & ( ) Discordo & ( ) Discordo \\
\hline ( ) Não sei & ( ) Não sei & ( ) Não sei & ( ) Não sei & ( ) Não sei & ( ) Não sei & ( ) Não sei & ( ) Não sei \\
\hline ( ) Concordo & ( ) Concordo & ( ) Concordo & ( ) Concordo & ( ) Concordo & ( ) Concordo & ( ) Concordo & ( ) Concordo \\
\hline $\begin{array}{l}\text { ( ) Discordo } \\
\text { Totalmente }\end{array}$ & $\begin{array}{l}\text { ( ) Discordo } \\
\text { Totalmente }\end{array}$ & $\begin{array}{l}\text { ( ) Discordo } \\
\text { Totalmente }\end{array}$ & $\begin{array}{l}\text { ( ) Discordo } \\
\text { Totalmente }\end{array}$ & $\begin{array}{l}\text { ( ) Discordo } \\
\text { Totalmente }\end{array}$ & $\begin{array}{l}\text { ( ) Discordo } \\
\text { Totalmente }\end{array}$ & $\begin{array}{l}\text { ( ) Discordo } \\
\text { Totalmente }\end{array}$ & $\begin{array}{l}\text { ( ) Discordo } \\
\text { Totalmente }\end{array}$ \\
\hline
\end{tabular}


A postura do(s) apresentador(es) pode ser considerada séria e profissional.

(VIDE VERSO)

\begin{tabular}{|c|c|c|c|c|c|c|c|}
\hline $\begin{array}{c}\text { Redes Neur. } \\
\text { Art. }\end{array}$ & Lógica Fuzzy & Alg. Genéticos & Sist. Inf. Geog. & Aval. Multicrit. & $\begin{array}{l}\text { Autôm. } \\
\text { Celular }\end{array}$ & $\begin{array}{c}\text { Sim. } \\
\text { Annealing }\end{array}$ & Est. Espacial \\
\hline $\begin{array}{l}\text { ( ) Concordo } \\
\text { Totalmente }\end{array}$ & $\begin{array}{l}\text { ( ) Concordo } \\
\text { Totalmente }\end{array}$ & $\begin{array}{l}\text { ( ) Concordo } \\
\text { Totalmente }\end{array}$ & $\begin{array}{l}\text { ( ) Concordo } \\
\text { Totalmente }\end{array}$ & $\begin{array}{l}\text { ( ) Concordo } \\
\text { Totalmente }\end{array}$ & $\begin{array}{l}\text { ( ) Concordo } \\
\text { Totalmente }\end{array}$ & $\begin{array}{l}\text { ( ) Concordo } \\
\text { Totalmente }\end{array}$ & $\begin{array}{l}\text { ( ) Concordo } \\
\text { Totalmente }\end{array}$ \\
\hline ( ) Discordo & ( ) Discordo & ( ) Discordo & ( ) Discordo & ( ) Discordo & ( ) Discordo & ( ) Discordo & ( ) Discordo \\
\hline ( ) Não sei & ( ) Não sei & ( ) Não sei & ( ) Não sei & ( ) Não sei & ( ) Não sei & ( ) Não sei & ( ) Não sei \\
\hline ( ) Concordo & ( ) Concordo & ( ) Concordo & ( ) Concordo & ( ) Concordo & ( ) Concordo & ( ) Concordo & ( ) Concordo \\
\hline $\begin{array}{l}\text { ( ) Discordo } \\
\text { Totalmente }\end{array}$ & $\begin{array}{l}\text { ( ) Discordo } \\
\text { Totalmente }\end{array}$ & $\begin{array}{l}\text { ( ) Discordo } \\
\text { Totalmente }\end{array}$ & $\begin{array}{l}\text { ( ) Discordo } \\
\text { Totalmente }\end{array}$ & $\begin{array}{l}\text { ( ) Discordo } \\
\text { Totalmente }\end{array}$ & $\begin{array}{l}\text { ( ) Discordo } \\
\text { Totalmente }\end{array}$ & $\begin{array}{l}\text { ( ) Discordo } \\
\text { Totalmente }\end{array}$ & $\begin{array}{l}\text { ( ) Discordo } \\
\text { Totalmente }\end{array}$ \\
\hline
\end{tabular}

A apresentação (escrita e oral) demonstra domínio do tema.

\begin{tabular}{|c|c|c|c|c|c|c|c|}
\hline $\begin{array}{c}\text { Redes Neur. } \\
\text { Art. }\end{array}$ & Lógica Fuzzy & Alg. Genéticos & Sist. Inf. Geog. & Aval. Multicrit. & $\begin{array}{l}\text { Autôm. } \\
\text { Celular }\end{array}$ & $\begin{array}{c}\text { Sim. } \\
\text { Annealing }\end{array}$ & Est. Espacial \\
\hline $\begin{array}{l}\text { ( ) Concordo } \\
\text { Totalmente }\end{array}$ & $\begin{array}{l}\text { ( ) Concordo } \\
\text { Totalmente }\end{array}$ & $\begin{array}{l}\text { ( ) Concordo } \\
\text { Totalmente }\end{array}$ & $\begin{array}{l}\text { ( ) Concordo } \\
\text { Totalmente }\end{array}$ & $\begin{array}{l}\text { ( ) Concordo } \\
\text { Totalmente }\end{array}$ & $\begin{array}{l}\text { ( ) Concordo } \\
\text { Totalmente }\end{array}$ & $\begin{array}{l}\text { ( ) Concordo } \\
\text { Totalmente }\end{array}$ & $\begin{array}{l}\text { ( ) Concordo } \\
\text { Totalmente }\end{array}$ \\
\hline ( ) Discordo & ( ) Discordo & ( ) Discordo & ( ) Discordo & ( ) Discordo & ( ) Discordo & ( ) Discordo & ( ) Discordo \\
\hline ( ) Não sei & ( ) Não sei & ( ) Não sei & ( ) Não sei & ( ) Não sei & ( ) Não sei & Não sei & ( ) Não sei \\
\hline ( ) Concordo & ( ) Concordo & ( ) Concordo & ( ) Concordo & ( ) Concordo & ( ) Concordo & Concordo & ( ) Concordo \\
\hline $\begin{array}{l}\text { ( ) Discordo } \\
\text { Totalmente }\end{array}$ & $\begin{array}{l}\text { ( ) Discordo } \\
\text { Totalmente }\end{array}$ & $\begin{array}{l}\text { ( ) Discordo } \\
\text { Totalmente }\end{array}$ & $\begin{array}{l}\text { ( ) Discordo } \\
\text { Totalmente }\end{array}$ & $\begin{array}{l}\text { ( ) Discordo } \\
\text { Totalmente }\end{array}$ & $\begin{array}{l}\text { ( ) Discordo } \\
\text { Totalmente }\end{array}$ & $\begin{array}{l}\text { ( ) Discordo } \\
\text { Totalmente }\end{array}$ & $\begin{array}{l}\text { ( ) Discordo } \\
\text { Totalmente }\end{array}$ \\
\hline
\end{tabular}


O material de apoio está bem elaborado, tratando do tema proposto de forma concisa (dentro do tempo proposto), mas em perder a clareza.

\begin{tabular}{|c|c|c|c|c|c|c|c|}
\hline $\begin{array}{c}\text { Redes Neur. } \\
\text { Art. }\end{array}$ & Lógica Fuzzy & Alg. Genéticos & Sist. Inf. Geog. & Aval. Multicrit. & $\begin{array}{l}\text { Autôm. } \\
\text { Celular }\end{array}$ & $\begin{array}{c}\text { Sim. } \\
\text { Annealing }\end{array}$ & Est. Espacial \\
\hline $\begin{array}{l}\text { ( ) Concordo } \\
\text { Totalmente }\end{array}$ & $\begin{array}{l}\text { ( ) Concordo } \\
\text { Totalmente }\end{array}$ & $\begin{array}{l}\text { ( ) Concordo } \\
\text { Totalmente }\end{array}$ & $\begin{array}{l}\text { ( ) Concordo } \\
\text { Totalmente }\end{array}$ & $\begin{array}{l}\text { ( ) Concordo } \\
\text { Totalmente }\end{array}$ & $\begin{array}{l}\text { ( ) Concordo } \\
\text { Totalmente }\end{array}$ & $\begin{array}{l}\text { ( ) Concordo } \\
\text { Totalmente }\end{array}$ & $\begin{array}{l}\text { ( ) Concordo } \\
\text { Totalmente }\end{array}$ \\
\hline ( ) Discordo & ( ) Discordo & ( ) Discordo & ( ) Discordo & ( ) Discordo & ( ) Discordo & ( ) Discordo & ( ) Discordo \\
\hline ( ) Não sei & ( ) Não sei & ( ) Não sei & ) Não sei & ) Não sei & ( ) Não sei & Não sei & Não sei \\
\hline Concordo & ( ) Concordo & ( ) Concordo & Concordo & Concordo & Concordo & Concordo & Concordo \\
\hline $\begin{array}{l}\text { ( ) Discordo } \\
\text { Totalmente }\end{array}$ & $\begin{array}{l}\text { ( ) Discordo } \\
\text { Totalmente }\end{array}$ & $\begin{array}{l}\text { ( ) Discordo } \\
\text { Totalmente }\end{array}$ & $\begin{array}{l}\text { ( ) Discordo } \\
\text { Totalmente }\end{array}$ & $\begin{array}{l}\text { ( ) Discordo } \\
\text { Totalmente }\end{array}$ & $\begin{array}{l}\text { ( ) Discordo } \\
\text { Totalmente }\end{array}$ & $\begin{array}{l}\text { ( ) Discordo } \\
\text { Totalmente }\end{array}$ & $\begin{array}{l}\text { ( ) Discordo } \\
\text { Totalmente }\end{array}$ \\
\hline
\end{tabular}

